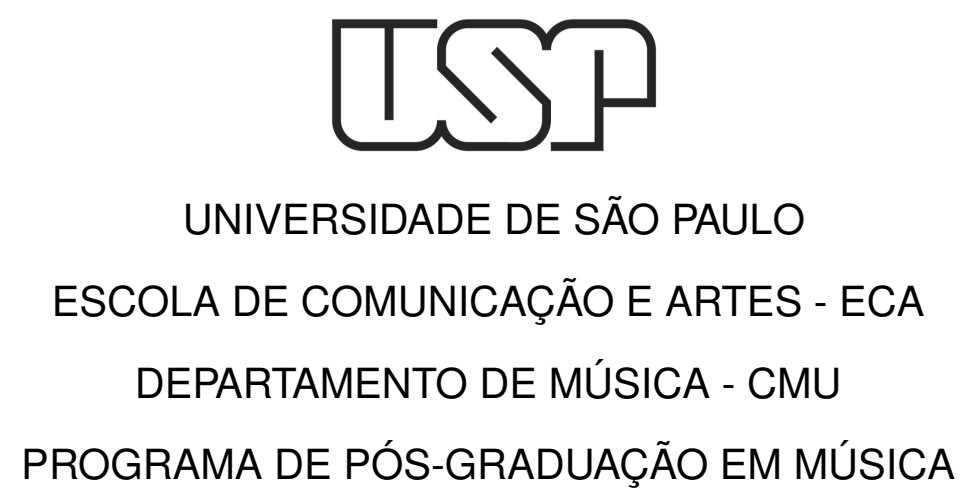

LUZILEI ALIEL

\title{
Ensaios sobre comprovisações em ecologia sonora: perspectivas práticas e teóricas
}

\author{
DISSERTAÇÃO DE MESTRADO
}

V.1

São Paulo 


\section{Ensaios sobre comprovisações em ecologia sonora: perspectivas práticas e teóricas}

Dissertação de Mestrado apresentado ao Programa de Pós-Graduação em Música PPGMUS, da Universidade de São Paulo, como parte dos requisitos necessários à obtenção do título de Mestre em Música com ênfase em Processos Criativos.

Orientador: Rogério Luiz Morais Costa Coorientador: Damián Keller

V.1

São Paulo 
Autorizo a reprodução e divulgação total ou parcial deste trabalho, por qualquer meio convencional ou eletrônico, para fins de estudo e pesquisa, desde que citada a fonte.

Catalogação na Publicação Serviço de Biblioteca e Documentação

Escola de Comunicações e Artes da Universidade de São Paulo Dados fornecidos pelo(a) autor(a)

Aliel, Luzilei

Ensaios sobre Comprovisações em Ecologia Sonora:

Perspectivas Práticas e Teóricas / Luzilei Aliel. -- São

Paulo: L. Aliel, 2017.

145 p.: il.

Dissertação (Mestrado) - Programa de Pós-Graduação em Música - Escola de Comunicações e Artes / Universidade de São Paulo.

Orientador: Rogério Costa

Coorientador: Damián Keller

Bibliografia

1. Ecologia Sonora 2. Comprovisação 3. Sistemas Socioecológicos I. Costa, Rogério II. Título.

CDD 21. ed. -780 
ALIEL, L. Ensaios sobre comprovisações em ecologia sonora: Perspectivas práticas e teóricas. Dissertação apresentada à Escola de Comunicação e Artes da Universidade de São Paulo para obtenção do título de Mestre em Processos Criativos.

Aprovado em:

Banca Examinadora

Prof. Dr. Instituição:

Julgamento: Assinatura:

Prof. Dr. Instituição:

Julgamento: Assinatura:

Prof. Dr. Instituição:

Julgamento: Assinatura: 
Dicata omnes qui credunt et non credunt ... 


\section{Agradecimentos}

Agradeço a todos que encontrei neste novo horizonte;

Ao meu eterno amor Liliane, que me fez seguir adiante;

Aos meus pais (Leila \& Luiz) que me ofereceram o amor como fonte;

Ao digníssimo orientador Rogério Costa pelo profundo conhecimento inebriante;

Ao amável e ilustríssimo coorientador Damián Keller e seu toque de Midas;

Ao Saru por me acompanhar nas noites mais desacolhidas;

À FAPESP - Fundação de Amparo à Pesquisa do Estado de São Paulo - pela bolsa concedida e cumplicidade;

À USP - Universidade de São Paulo - pela oportunidade; 
O silêncio parece falar; as sombras se povoam de seres invisíveis; os objetos, na sua imobilidade, como que oscilam pelo espaço. É ao mesmo tempo o nada com o seu vácuo profundo, imenso, infinito; e o caos com a sua confusão, as suas trevas, as suas formas incriadas; a alma sente que falta-lhe a vida ou a luz em torno (José de Alencar - O Guarani) 


\section{Resumo}

Esta pesquisa teve como objetivo investigar a inclusão da improvisação sonora em práticas ecológicas, como paisagem sonora, ecocomposição e ecologia sonora. Com ênfase em práticas de ecologia sonora da perspectiva de Costa (2014) e Solomos, (2012) atribuímos a improvisação sonora, juntamente com o processo de composição sonora, denominado comprovisação. A comprovisação é sugerida nesta pesquisa como uma estratégia para incluir processos estruturais através de regras (plano de diretrizes) e ações de contingência (plano de contingência). Os dois planos nos permitiram gerar, analisar, replicar e discutir dados para práticas ecológicas que misturam composição e improvisação sonora. Compreendemos as práticas de comprovisação ecológica como consistentes com as discussões de Fujak (2011), onde todas as ações podem ser planejadas, mas são as contingências imprevisíveis que alteram todo o sistema tornando-o mutável e adaptável (como a vida). Devido à ausência de material bibliográfico sobre improvisação em práticas ecológicas, procuramos alinhar a modelagem de sistemas socioecológicos, que são abordagens que formalizam sistemas dinâmicos adaptativos em três pilares principais: recursos materiais, recursos cognitivos e interação entre agentes, com as práticas de comprovisação ecológica. Desta forma, propomos dois modelos para a criação de práticas ecológicas comprovisatórias: PMSE (proposta de modelagem em síntese ecológica) expandindo as obras de Keller (1999) e PL (Proposta de modelagem de looping) expandindo as obras de Di Scipio (2003). Com a formalização dos sistemas socioecológicos e a metodologia da comprovisação, construímos quatro performances/experimentos que serviram de estudo de caso, sendo: Destino Pirilampo, Citações , Lyapunov Time, The Maxwell Demon. Através de dois métodos de análise que foram expandidos neste trabalho, sendo um qualitativo: MM (modelo MANNIS, 2014) e um quantitativo: MDF (Dentro-Fora - FERRAZ; KELLER, 2014), conseguimos estruturar de forma satisfatória um viés de obras artísticas que têm orientação em práticas ecológicas e que estabelecem contingências como recurso de adaptação do ambiente sonoro. Concentramos-nos na análise de recursos materiais (acústica, eletrônica e ambiental), recursos cognitivos (interação consensual, intencionalidade e tomada de decisão) e interação entre agentes: performáticos (músicos), incisos (não músicos) e entidade gelassenheit (imprevisibilidade, aleatoriedade). 


\begin{abstract}
This research aimed to investigate the inclusion of sound improvisation in ecological practices such as soundscape, ecocomposition and sound ecology. With emphasis on sound ecology practices from the perspective of Costa (2014) and Solomos, (2012) we attribute sound improvisation, together with the process of sound composition, called comprovisation. The comprovisation is suggested in this research as a strategy to include structural processes through rules (plan of guidelines) and contingency actions (contingency plan). The two plans allowed us to generate, analyze, replicate and discuss data for ecological practices that mix composition and sound improvisation. We understand ecological comprovisation practices as consistent with Fujak's (2011) discussions, where all actions can be planned, but unpredictable contingencies that alter the whole system making it changeable and adaptable (such as life). Due to the lack of bibliographic material on improvisation in ecological practices, we seek to align the modeling of socioecological systems, which are approaches that formalize adaptive dynamical systems in three main pillars: material resources, cognitive resources, and interaction between agents, with practices of ecological comprovisation. In this way, we propose two models for creating ecological comprovisation practices: PMES (Proposal modeling ecological synthesis) expanding Keller works, (1999) and PL (Proposal looping modeling) expanding Di Scipio works (2003). With the formalization of the socioecological systems and the methodology of the comprovisation, we constructed four performances/experiment that served as a case study, they are: Destination Firefly, Quotations , Lyapunov Time, The Maxwell Demon. In view of two methods of analysis that were expanded in this work, a qualitative one: MM (MANNIS Model, 2014) and a quantitative one: MDF (Inside-Outside - FERRAZ; KELLER, 2014), we were able to satisfactorily structure a bias of artistic works That have orientation in ecological practices and that establish contingencies as a resource of adaptation of the sound environment. We focus on the analysis of material resources (acoustic, electronic and environmental) cognitive resources (consensual interaction, intentionality and decision making) and interaction between agents musicians, non-musicians and entity gelassenheit (unpredictability, randomness).
\end{abstract}




\section{Lista de ilustrações}

Figura 1 - Modelo de Percepção (Schulte-Fortkamp; Fiebig, 2006 p.2) . . . . . 25

Figura 2 - Um meta-modelo para a modelagem formal de sistemas socioecológicos. . . . . . . . . . . . . . . . . . . . 42

Figura 3 - Modelo de sistema de retroalimentação em looping proposto por Di Scipio . . . . . . . . . . . . . . . . . . . . 51

Figura 4 - Diagrama do Modelo Mannis (2014): Percepção-Análise-Síntese. . . 56

Figura 5 - Diagrama do fluxo ocorrente durante a performance de Destino Pirilampo . . . . . . . . . . . . . . . . . . . 77

Figura 6 - Imagem de um momento da performance do projeto Destino Pirilampo. 83

Figura 7 - Poema e Procedimentos para Live Electronics em Citações . . . . 89

Figura 8 - Procedimentos para a voz em Citações $\sim \ldots$. . . . . . . . . . . . . . 90

Figura 9 - Pêndulo Composto em Estado Regular . . . . . . . . . . . . . . . . 94

Figura 10 - Pêndulo Composto em Estado Irregular. . . . . . . . . . . . . . . . . 95

Figura 11 - Página I de LYT . . . . . . . . . . . . . . . . . . . . . . . . . . 96

Figura 12 - Página Il de LYT . . . . . . . . . . . . . . . . . . . . . . . . . . . . 98

Figura 13 - Página III de LYT . . . . . . . . . . . . . . . . . . . . . . . . . . . . 99

Figura 14 - Página IV de LYT . . . . . . . . . . . . . . . . . . . . . . . . . 100

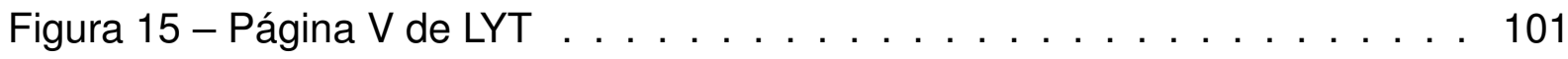

Figura 16 - Página VI de LYT . . . . . . . . . . . . . . . . . . . . . . . . . . . . . 102

Figura 17 - Página VII de LYT . . . . . . . . . . . . . . . . . . . . . . . . . . . . 102

Figura 18 - Exemplo de performance em LYT . . . . . . . . . . . . . . . . . . . . 106

Figura 19 - Interface do patch de celular de "The Maxwell Demon" . . . . . . . 113

Figura 20 - Cena da primeira performance/experimento . . . . . . . . . . . . . . 116

Figura 21 - Cena da segunda performance/experimento . . . . . . . . . . . . . 119

Figura 22 - Cena da terceira performance/experimento . . . . . . . . . . . . . . 120 


\section{Lista de abreviaturas e siglas}

$\begin{array}{ll}\text { ADSR } & \text { Attack, Decay, Sustain and Release } \\ \text { AESI } & \text { Audible Eco-Systemic Interface } \\ \text { FM } & \text { Frequency Modulation } \\ \text { GT } & \text { Grounded Theory } \\ \text { MDF } & \text { Modelo Dentro Fora } \\ \text { MM } & \text { Modelo Mannis } \\ \text { PD } & \text { Pure Data } \\ \text { PL } & \text { Proposta de Modelagem em Looping } \\ \text { TMD } & \text { The Maxwell Demon } \\ \text { VAC } & \text { Virtual Audio Cable }\end{array}$


Sumário

INTRODUÇÃO - PRÁTICAS CRIATIVAS ECOLÓGICAS . . . . . . . 14

REVISÃO DE LITERATURA: PRÁTICAS ECOLÓGICAS E ECOLO-

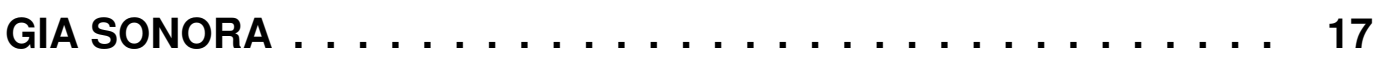

$2.1 \quad$ Bibliografia Histórica . . . . . . . . . . . . . . . . . . . . . . . 19

2.1.1 Práticas Ecológicas Hoje . . . . . . . . . . . . . . . . . . . . . . . 23

$2.1 .2 \quad$ Grounded Theory . . . . . . . . . . . . . . . . . . . 23

2.1.3 Ecocomposição . . . . . . . . . . . . . . . 26

2.1.4 Práticas Sonoras à partir de uma Perspectiva Ecocomposicional . . 27

3 COMPROVISAÇÃO . . . . . . . . . . . . . . . . 30

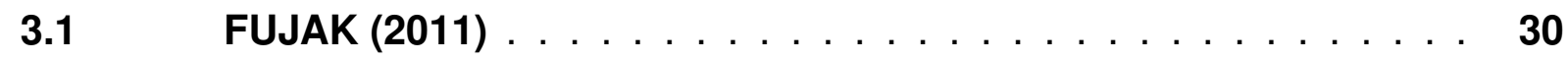

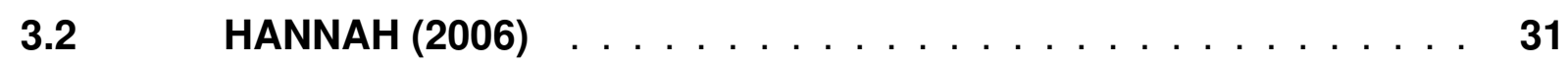

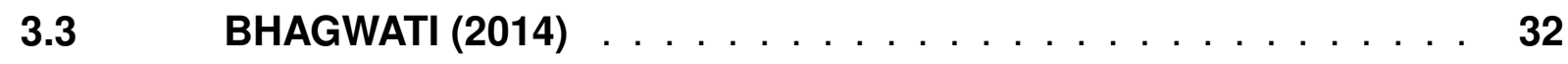

$3.4 \quad$ DUDAS (2010) $\ldots \ldots \ldots \ldots \ldots \ldots$

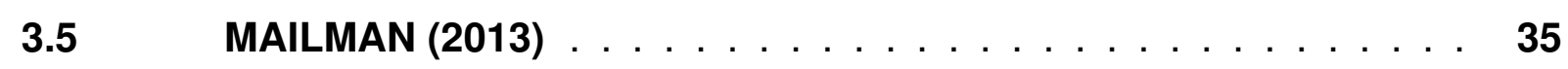

3.6 Considerações Sobre as Propostas Comprovisatórias . . . . . . 35

3.7 Discussões sobre Comprovisação na Ecologia Sonora . . . . . . 38

4 MODELAGENS DE SISTEMAS SOCIOECOLÓGICOS ADAPTÁVEIS - FORMALIZAÇÃO PARA COMPROVISAÇÕES EM ECOLOGIA SONORA ......................... 40

$4.1 \quad$ Um Meta-modelo de Entidade-Processo . . . . . . . . . . . . . . . 41

$4.2 \quad$ Estrutura do Sistema: Entidades e Relações . . . . . . . . . . . . 41

4.3 Sistema Dinâmico: Processos e Comportamentos . . . . . . . . . 43

4.4 Interações entre o Sistema e Meio Ambiente . . . . . . . . . . . . 44

4.5 Comportamento e Dinâmica dos Diagramas . . . . . . . . . . . 44

$4.6 \quad$ Cenários e Indicadores . . . . . . . . . . . . . . . . . . . 45

4.7 Documentação do Modelo e Cenários . . . . . . . . . . . . . . . . 45

4.8 Modelo de Simulação - Modelo de Performance/Experimento . . 46

4.9 Modelo de Simulação 1- Proposta de Modelagem de Síntese Ecológica (PMSE) . . . . . . . . . . . . . . . . . . . . . . . . . . . . . . . 47

4.10 Modelo de Simulação 2 - Proposta de Modelagem em Looping - PL 49

$4.11 \quad$ Formalizando a Modelagem em Looping . . . . . . . . . . . . . . 53

5 METODOLOGIA ANALÍTICA - ASPECTOS TEÓRICOS PARA ANÁLISE DOS ESTUDOS DE CASO . . . . . . . . . . . . . . . . . . . . 55 


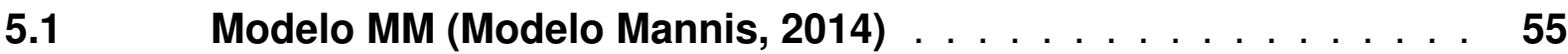

$5.2 \quad$ Modelo Dentro-Fora . . . . . . . . . . . . . . . . . . . . 59

5.3 Aplicações e Verificação dos Modelos MM e MDF . . . . . . . . 62

6 PERSPECTIVAS ECOLÓGICAS EM COMPROVISAÇÃO: ABORDAGENS, INTENCIONALIDADE, INTERAÇÃO E AGENCIAMENTO 63

6.1 Dilatação das Abordagens Metodológicas e Discussão . . . . . . 63

6.2 Intencionalidade em Processos Ecológicos Comprovisados

$6.3 \quad$ Interação Consensual . . . . . . . . . . . . . . . 67

$7 \quad$ ESTUDOS DE CASO $\ldots \ldots \ldots \ldots \ldots \ldots$

$7.1 \quad$ Estudo de Caso 1: Projeto Destino Pirilampos . . . . . . . . 74

7.1.1 Recursos Materiais e Métodos (Plano de Diretrizes) . . . . . . 76

7.1.1.1 Recursos Materiais Eletrônicos . . . . . . . . . . . . . . . . 76

7.1.2 Plano de Contingência e Modelagem Socioecológica . . . . . . . . . 78

7.1.3 Instâncias (similaridades) e Observação de Interação entre Agentes 78

7.1.4 Recursos Cognitivos . . . . . . . . . . . . . . . . . . . 79

7.1.5 Relações Permanentemente Estruturais (Natureza - Criatividade); Relações Permanentemente Não-Estruturais - Resultado de Ações

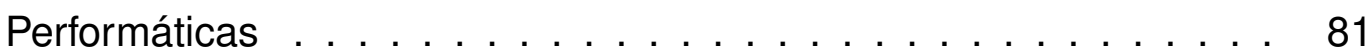

7.1.6 Comportamento: (MM) - Processo Ecológico/Sociológico/Atividade . 83

7.1.7 Entidade de Interface: (MDF) Impactos de Fontes Externas e Internas 84

7.1.8 Processos, Comportamentos e Cenários: Resenha das Transformações da Performance - PMSE - Dinâmica/Impacto/Estágio inicial-Vínculo 84

$7.2 \quad$ Estudo de Caso 2: Citações $\sim \ldots \ldots \ldots$

7.2.1 Recursos Materiais e Métodos (Plano de Diretrizes) . . . . . . . . 85

7.2.2 Recursos Materiais Eletrônicos . . . . . . . . . . . . . . . 85

7.2.3 Recursos Materiais Acústicos: Voz . . . . . . . . . . . . . 89

7.2 .4 Recursos Cognitivos . . . . . . . . . . . . . . . . . . . 91

7.2.5 Plano de Contingência e Modelagem Socioecológica . . . . . . . . . 91

7.2.5.1 Instâncias (similaridades) e Observação de Interação entre Agentes . . . . . . . 91

7.2.5.2 Processos, Comportamentos e Cenários: Resenha das Transformações da Performance - PL - Dinâmica/lmpacto/Estágio inicial-Vínculo . . . . . . . . . . . . 92

7.2.5.3 Entidade de Interface: (MDF) Impactos de Fontes Externas e Internas . . . . . . 93

7.3 Estudo de Caso 3: "Lyapunov Time" . . . . . . . . . . . . . 93

7.3.1 Recursos Materiais e Métodos (Plano de Diretrizes) . . . . . . . 94

7.3.1.1 Recursos Materiais Acústicos . . . . . . . . . . . . . . . . . . . . 94

7.3.1.2 Recursos Materiais Eletrônicos . . . . . . . . . . . . . . . . . 103

7.3.1.3 Processamento de Áudio e Recursos Comprovisatórios. . . . . . . . . . . . . . 103 
7.3.2 Plano de Contingência e Modelagem Socioecológica . . . . . . . . 105

7.3.2.1 Processamento em Vídeo como Plano Contingencial . . . . . . . . . . . . . 105

7.3.2.2 Plano Contingencial em Live Electronics . . . . . . . . . . . . . . . . . . 107

7.3.3 Recursos Cognitivos . . . . . . . . . . . . . . . . . . . . 107

7.3.4 Análise de Recursos Materiais e Recursos Cognitivos . . . . . . . . . 107

7.3.5 Processos, Comportamentos e Cenários: Resenha das Transformações da Performance - PMSE/PL - Dinâmica/Impacto/Estágio inicialVínculo . . . . . . . . . . . . . . . . . . . . . . . . . . . . 108

7.3.6 Entidade de Interface: (MDF) Impactos de Fontes Externas e Internas 108

7.3.7 Comportamento: (MM) - Processo Ecológico/Sociológico/Atividade . 109

7.3.8 Instâncias (similaridades) e Observação de Interação entre Agentes 110

$7.4 \quad$ Estudo de Caso 4: "The Maxwell Demon" (TMD). . . . . . . . . . 110

7.4.1 Recursos Materiais e Métodos (Plano de Diretrizes) . . . . . . . . 111

7.4.1.1 Recursos Materiais Eletrônicos . . . . . . . . . . . . . . . . . . . 112

7.4.2 Plano de Contingência e Modelagem Socioecológica . . . . . . . . . 114

7.4.3 Processos, Comportamentos e Cenários: Resenha das Transformações da Performance - PMSE - Dinâmica/Impacto/Estágio inicial-Vínculo115

7.4.4 Instâncias (Similaridades) e Observação de Interação entre Agentes 116

7.4.5 Relações Permanentemente Estrutural - Relações Permanentemente Não-Estrutural - Resultado de Ações Performáticas - Mimese . . . . 121

7.4.6 Comportamento: (MM) - Processo Ecológico/Sociológico/Atividade . 122

7.4.7 Entidade de Interface: (MDF) Impactos de Fontes Externas e Internas 123

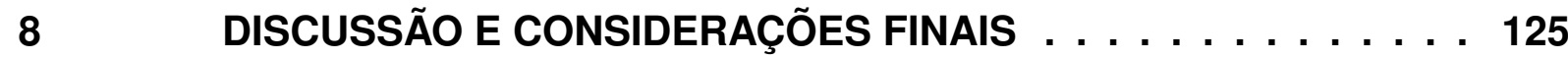




\section{Introdução - Práticas Criativas Ecológicas}

Até o final da década de sessenta, se aproximando de uma metodologia orgânica para a arte sonora (como idealizada preliminarmente na década de 1930 por Edgard Varèse - Wen-Chung, 1966), as abordagens ecológicas com propostas composicionais propuseram ações criativas como subprodutos de ciclos de ação-percepção. Nestas práticas de composição ecológicas, a atividade criativa é concebida como a interação entre agentes e objetos (KELLER, 2000). A criatividade não é atribuída exclusivamente aos fatores individuais ou pessoais. Para além do suporte cognitivo ela tem tanto uma dimensão social quanto uma dimensão material (KELLER et al., 2011). A troca de conhecimento através da interação social é portanto um fator importante na gestação de processos e de produtos criativos. Concomitantemente, os contextos onde acontecem as atividades criativas podem fomentar ou limitar os tipos de resultados (KELLER et al. 2013). Os enfoques ecológicos dão destaque para a função dos objetos materiais como suporte para as decisões criativas.

Neste trabalho, buscaremos uma expansão das práticas ecológicas incorporando o uso da improvisação sonora para propor novos desafios conceituais e técnicos. Em outra perspectiva, introduziremos o conceito da improvisação sonora como recurso capaz de gerar, propagar e estabelecer propriedade relevantes aos estudos da ecologia sonora.

COSTA [2014] vincula o conceito de ecologia sonora (SOLOMOS, 2012) com as propriedades sonoras emergentes observadas na prática da improvisação livre. $O$ autor sugere que o conceito de livre improvisação pode estabelecer uma ponte entre a composição instrumental e a ecologia sonora:

Na livre improvisação, os músicos interagem em tempo real entre si
e com o ambiente da improvisação. Na verdade, a atuação criativa e
interativa dos músicos (com seus instrumentos, suas histórias pessoais,
vontades e potências), tanto quanto o espaço e o tempo específicos de
cada performance, constituem o ambiente complexo da improvisação.
Pode-se dizer que cada performance se configura de uma forma abso-
lutamente singular ou, em outras palavras, que cada performance cria
e é um novo ambiente específico. Neste sentido, é possível dizer que a
prática da livre improvisação se localiza no campo intermediário entre a
música, em seu sentido tradicional, e a ecologia sonora (COSTA, 2014).

A partir do apontamento de COSTA (2014) podemos levantar as questões de quando e como a improvisação sonora pode (poderia) influenciar em processos ecológicos? Em nossa perspectiva, o autor se propõe a indicar posicionamentos sobre improvisação livre como uma forma de ecologia sonora, evidenciando características 
similares entre ambas atividades. Entretanto, não estabelece a improvisação livre como factualmente uma ecologia sonora, e sim como um campo intermediário entre a música tradicional e a ecologia sonora em relação a improvisação livre. Desta forma, questionamos neste trabalho, qual o campo não intermediário, e sim estrutural que se pode estabelecer com a improvisação sonora (não somente a livre) em um universo ecológico? Existe este lugar? As práticas composicionais ecológicas se associariam de alguma forma às práticas improvisatórias ecológicas?

Abordando alguns paradigmas ecológicos, encontramos no cerne da discussão: (1) a interação social como eixo dos processos criativos (BASANTA, 2010; KELLER; CAPASSO, 2006; NANCE, 2007), (2) a utilização dos ambientes (lugar) como âmbito ideal para a prática artística (KELLER et al., 2011), e (3) o incentivo à atividade exploratória e atividade epistêmica através do uso de recursos locais (BURTNER, 2005). (4) a formalização e desenvolvimento de sistemas socioecológicos como ferramentas de análise, medição de ambientes auto-reguláveis e adaptados (SIBERTIN-BLANC et al. 2011).

É relevante apontar que a improvisação sonora é um âmbito que até recentemente não tinha sido abordado a partir de uma perspectiva ecológica, o que torna necessário uma formalização de vários conteúdos para posicionar uma pesquisa relevante à área. Consideramos neste trabalho abordar diversos conteúdos de múltiplas áreas do saber que possam ser significativos para implementação de recursos improvisatórios em ecologia sonora. Optamos pela criação e execução de performances/experimentos para a captação de dados capazes de traduzir informação de como sistemas socioecológicos interagem com atividades tão singulares como a improvisação. As performances/experimentos são atividades artísticas desenvolvidas para possibilitar a experimentação e medição de condições quantitativas e qualitativas de um sistema, entretanto, essas atividades são em seu âmago performances. Ou seja, a obra artística sendo explorada a partir de duas dimensões: a performance e o experimento científico. Cada performance/experimento deste trabalho foi considerado como um estudo de caso. Através de diversas performances e análises buscamos desenvolver uma perspectiva metodológica/análitica da ecologia sonora comprovisada. Uma condição onde as estratégias de composição ecológicas existentes se amalgamam em condições improvisatórias. Apresentamos a seguir os diversos segmentos desenvolvidos para elaboração de um plano comprovisacional ecológico:

No capítulo II, uma breve revisão de literatura com objetivo de trazer um recorte do quadro da pesquisa em ecologia sonora desde seu princípio, compreendida como Soundscape (paisagem sonora) até algumas teorias atuais e conceitos ecocomposicionais.

No capítulo III, abordaremos a metodologia da comprovisação. Sistema que 
utiliza tanto planos de diretrizes (composição) como planos contingenciais (improvisação). Produzimos um levantamento da pesquisa na área e abordamos a necessidade e utilização da comprovisação em ecologia sonora

No capítulo IV, abordamos a discussão dos sistemas socioecológicos diante as perspectivas de Reed, (2008); Pahl-Wostl, (2007); Giampietro, (2002); Rotmans; Asselt, (1996); Sibertin-Blanc et al (2011) e introduzimos duas propostas de modelagem para comprovisações ecológicas: Proposta de Modelagem de Síntese Ecológica (PMSE) (KELLER, 1999) e a Proposta de Modelagem em Looping (PML) (ALIEL et al. 2016)

No capítulo $\mathrm{V}$, abordamos metodologias analíticas composicionais que buscam elucidar os processos de criação sonora sob uma ótica da auto-organização orgânica. São levantadas questões sobre como perceber, analisar e sintetizar os processos criativos. Usamos as abordagens: Modelo MM (Mannis, 2014) e Modelo MDF (Modelo Dentro-Fora - Ferraz e Keller, 2012). São também problematizadas questões como auto-organização sonora, crescimento orgânico sonoro homogêneo e heterogêneo e questões sobre a criatividade coletiva e individual.

No capítulo $\mathrm{VI}$, discutimos as possíveis expansões dos processos analíticos focando nos processos de subdivisão dos agentes, a interação consensual entre os agentes e a tomada de decisão (intencionalidade) em ação.

No capítulo VII, entramos nos estudos de caso de peças que se esforçam para criar conexões entre comprovisações e princípios da ecologia sonora. São adicionadas obras de outros comprovisadores que trazem características que se associam às intervenções entre improvisação instrumental e ecologia sonora, objeto relevante ao nosso estudo. As peças são: Projeto Destino Pirilampo (Aliel; Fornari, 2013), Citações (Aliel et al, 2015), LYT (Aliel, 2016), TMD (Aliel, 2016) São apresentadas as descrições das propostas, dos métodos e dos resultados obtidos nos projetos artísticos.

Capítulo VIII, encontramos as discussões finais sobres os parâmetros discutidos nesta dissertação tais como: improvisação em ambientes ecológicos, ações de agentes, tipo de sistemas socioecológicos e métodos comprovisacionais e análiticos. 


\section{Revisão de Literatura: Práticas Ecológicas e Ecologia Sonora}

Uma ampla revisão da literatura sobre ecologia sonora torna-se uma tarefa complexa devido à multiplicidade da natureza do assunto e historicamente definições pouco claras sobre o conceito. Randolph (2009) propõe arquétipos para este tipo de revisão literária. Uma delas seria a abrangência de toda literatura, focada em amostras representativas, ou examinar apenas os textos-chave sobre o assunto. Embora esta escolha talvez seja simples para uma pesquisa, ou seja, abrangendo múltiplas áreas, a questão é um pouco mais complexa.

Esta revisão de literatura irá combinar dois fatores primordiais: abranger os textos principais e exemplificar amostras representativas de trabalhos em vários campos de pesquisa. Daremos o início com uma análise cronológica de como alguns termos entraram em uso popular; em seguida iremos nos dividir em variadas direções para explorar a atual pesquisa em ecologia sonora. Apontamos que esta revisão poderá não abranger todas as áreas de pesquisa desenvolvidas na área até o momento, como visto em revisões mais completas como de Payne et al. (2009). Dedicaremos nosso trabalho a uma visão geral dos trabalhos mais relevantes, conduzindo ao leitor uma base significativa para compreensão da área de atuação a ser executado nesta dissertação.

A pesquisa sobre ecologia sonora ocorre através de uma multiplicidade de áreas de concentração como a acústica, arquitetura e planejamento urbano. Nesta revisão de literatura, buscamos ampliar os conceitos que constituem a pesquisa em ecologia sonora. A pesquisa em ecologia sonora é uma área relativamente nova, tendo uma gama muito limitada de metodologias, além de uma gama ainda mais limitada de epistemologias utilizadas para a investigação deste campo. Listamos algumas críticas sobre a investigação existente, propondo outras formas de pensamento recorrentes na atualidade que podem ser desenvolvidas pela academia. Iniciamos com as propostas em paisagem sonora.

Embora o termo seja amplamente divulgado, não há uma definição singular do que exatamente é uma paisagem sonora. Há questionamentos sobre a validade do cunho do termo por Schafer (1977), sendo creditado por alguns pesquisadores a Southworth (1969). Entretanto, Schafer definiu o que compreendemos como paisagem sonora como uma área acadêmica. Schafer, integrou o World Soundscape Project, preocupando-se principalmente com o campo da ecologia acústica. Suas premissas consistem em dividir as paisagens sonoras em mais ou menos ruidosas, o que denominou Hi-Fi e Lo-Fi. Áreas campestres, rurais ou isoladas eram consideradas Hi-Fi, ou seja, baixos índices de ruído, enquanto áreas urbanas e afins eram altamente ruidosas 
sendo consideradas Lo-Fi. Schafer (1977), no entanto, nunca definiu claramente o que era uma paisagem sonora, apenas buscando demonstrar como ela operava em um quadro diário. Truax (2001) foi o primeiro autor a buscar uma definição:

[Paisagem sonora seria]... um ambiente de som (ou ambiente sonoro) com ênfase na forma como ele é percebido e compreendido pelo indivíduo, ou por uma sociedade. (TRUAX, 2001) $)^{1}$

Truax propõe desta forma, um foco no ouvinte e não no ambiente, enfatizando o indivíduo e o contexto social, em um mesmo patamar. Sua proposta é que a percepção seja a ferramenta pela qual são determinadas as características singulares de cada paisagem sonora, resultando em um estado de confluência entre indivíduo e meio ambiente. Sobre uma perspectiva similar, Schafer concentrou-se indiretamente sobre a percepção das pessoas dentro do ambiente sonoro. Seu principal objetivo tinha relação com a gravação de sons que poderiam vir a ser extintos, explorando conceitos do som como um elemento intrínseco de uma paisagem.

Payne et al. (2009b), escrevendo para D.E.F.R. ${ }^{2}$, propôs um resumo mais recente sobre a pesquisa acústica em paisagens sonoras.

O termo "paisagens sonoras" é por vezes considerado uma adaptação do termo visual de 'paisagens' (SCHAFER, 1977), transferindo o foco do visual para o ambiente sonoro. Atualmente não há concordância entre as definições de soundscapes (GENUIT; FIEBIG, 2006), mas o trabalho para uma definição tem sido reportado como: paisagens sonoras são a totalidade de todos os sons dentro de um local com ênfase nas relações entre a percepção do indivíduo ou sociedade, compreendendo a interação com o ambiente sonoro. Esta definição baseia-se nas definições originais de paisagem sonora e descrições da paisagem (DEFRA, 2007; SCHAFER, 1994; SCHILTE-FORTKAMP; DUBOIS, 2006; TRUAX, 1978). Soundscapes podem ser estudadas em uma estância micro (local, indivíduo. Por exemplo: parque urbano, rua, quarto), meso (área pequena. Por exemplo: área residencial, grande centro comercial) ou ao nível macro (grande área. Por exemplo, toda cidade). (PAYNE et al. 2009) ${ }^{3}$

1 An environment of sound (or sonic environment) with emphasis on the way it is perceived and understood by the individual, or by a society. (TRUAX, 2001)

2 Department for Environment, Food and Rural Affairs

3 The term 'soundscapes' is often considered an adaptation of the visual term 'landscapes' (Schafer, 1977), changing the focus from the visual to the sonic environment. Currently there is no one agreed definition of soundscapes (Genuit \& Fiebig, 2006), but a working definition for this report is as follows: soundscapes are the totality of all sounds within a location with an emphasis on the relationship between individual's or society's perception of, understanding of and interaction with the sonic environment. This definition is based upon original soundscape definitions and landscape descriptions (Defra, 2007; Schafer, 1994; Schulte-Fortkamp \& Dubois, 2006; Truax, 1978). Soundscapes can be studied at the micro (individual place, e.g. urban park, street, room), meso (small area, e.g. residential area, large shopping mall) or macro level (large area, e.g. whole city). 
A definição considerada por Payne traz uma similaridade com a definição proposta por Truax e Schafer. No entanto, a definição de Payne trata de relacionamentos e interação, em um parâmetro não meramente referente à compreensão, propondo paisagens sonoras como sendo interativas. Assim sendo, esta proposta sugere que a percepção do ambiente sonoro pode mudar de acordo com as relações de percepção do ouvinte. Estabelecem-se ainda apontamentos sobre como podem ser tratados os estudos em paisagem sonora, ou seja, micro, meso ou macro.

De um modo geral, podemos perceber uma grande divisão qualitativa/quantitativa em pesquisas de paisagens sonoras e ecologia sonora, entretanto quase todas as pesquisas quantitativas possuem conteúdos qualitativos e vice-versa (OAKLEY 1998). Atualmente existe um grande corpo de pesquisa, principalmente quantitativa, utilizando metodologias onde as "perguntas-fechadas" são analisadas em entrevistas como Componentes de Análise Principais, garantindo conhecimentos estatísticos em larga escala. Por outro lado, existe uma vertente relativamente pequena focada no processo antropológico ligado à ecologia, e até mesmo uma menor focada na área sociológica. Esta propõe investigações sobre fenômenos sociais em uma escala menor, entretanto com uma grande quantidade de detalhes.

Esta noção de divisão entre métodos "quantitativos" e métodos "quali-
tativos" [em pesquisas de paisagem sonora] eleva-se a um choque de
paradigmas, sendo estes suportados por uma característica marcante
de grande parte dos argumentos sobre métodos "quantitativos" contra
"qualitativos": quão pequena é a preocupação com a pertinência do
método para a questão de pesquisa. A escolha do método é ditada pelo
paradigma em vez da pergunta a ser abordada na pesquisa. (OAKLEY,
1998, p. 156).

Este trabalho, pretende indicar caracteristicas tanto qualitativas quanto quantitativas, tendo um enfoque nas caracteristicas socioecológicas do som. Consultaremos variadas metodologias, buscando fornecer recursos qualitativos/quantitativos relevantes.

\subsection{Bibliografia Histórica}

Uma revisão bibliográfica que verse sobre ecologia sonora tenderá a citar ou relatar os avanços na área dando primária ênfase às paisagens sonoras ou soundscapes, contribuição de R. Murray Schafer (1977) e do Projeto Mundial Soundscape (WSP). Apesar de haver hoje diversas obras substantivas nesta área, Schafer ainda é o maior contribuinte para o estabelecimento, compreensão, ensino e emancipação das paisagens sonoras. A composição de paisagens sonoras concentra-se principalmente no material sonoro. A princípio, Schafer relacionou uma associação das palavras "paisagem" (landscape) e "som" (sound) em soundscape (paisagem sonora). Este tipo de 
produto artístico prima pela inclusão de material sonoro inicialmente considerado como "não-musical" na criação musical contemporânea (KELLER, 2004), bem como a classificação de qualquer meio físico como possível gerador espontâneo de sons (SCHAFER, 2001). Paisagens sonoras são geradas por múltiplas fontes sonoras, que podem ser representadas como agentes externos de um sistema aberto e complexo que apresenta propriedades emergentes de auto-organização de significado sonoro. $O$ trabalho de Schafer embora tenha uma premissa ecológica, abrange diversas áreas: arte, música, acústica, ciências sociais, psicologia, saúde ambiental e design arquitetônico.

Uma das principais críticas ao trabalho de Schafer (SCHULTE-FORTKAMP; DUBOIS, 2006) é a proposta de colocar o ambiente "tranquilo" e rural em um pedestal acima de outros ambientes. Para Schafer a paisagem sonora da cidade é compreendida como desfavorável e até mesmo nociva. Seu desgosto por este tipo de paisagem é relatado diversas vezes em seus escritos. Embora tais textos tenham teor acadêmico, Schafer compõe uma narrativa incomum ao universo acadêmico, considerando diferentes fontes para sua retórica, exemplos como a Bíblia, a antropologia, gravações de sons, mapas e gráficos são encontrados em seus escritos, que por fim acabam por ignorar a complexidade e as multifacetas da paisagem sonora como um todo.

Aquém esta questão, seu trabalho no WSP foi substituído por Barry Truax, que publicou em 1984, (revisado em 2001) o livro Acoustic Communication, compêndio onde introduz um vocabulário acadêmico mais detalhado e específico para a discussão das paisagens sonoras:

Eu tentei no meu livro "Acoustic Communication" oferecer à área uma base intelectual. Essa base pode ser entendida como uma dupla crítica, primeiramente às disciplinas tradicionais que estudam algum aspecto do som, e em segundo, às ciências sociais interdisciplinares dos estudos de comunicação. A última crítica é baseada simplesmente no que considero ser um "ponto cego" na área das ciências sociais sobre qualquer assunto envolvendo percepção. (TRUAX, 1993) ${ }^{4}$

Especificamente ao tratarmos do termo "paisagem sonora", este foi relatado primeiramente nos estudos de Michael Southworth (1969, apud PAYNE et al. 2009). Southworth investigou a questão "multissensorial" em antagonismo às experiências "monosensoriais", e sugere a ideia do que Schafer iria chamar de "soundmarks": ou seja, áreas que eram identificáveis unicamente a partir da sua paisagem sonora. Southworth propõe desta forma, um olhar para o design multissensorial, sendo este mais eficaz, no contexto ambiental, do que focarmos em qualquer modalidade sensorial individual.

4 I have attempted in my book "Acoustic Communication" to give the field an intellectual basis. That basis can be understood as a twofold critique, firstly, of traditional disciplines that study some aspect of sound, and secondly, of the social science inter-discipline of communication studies itself. This latter critique is based simply on what I have found to be a "blind spot" in the social sciences regarding any subject involving perception. (Truax, 1993) 
Para Southworth a cidade não abre espaço para tornar notáveis as nuances sonoras de sua complexidade, limitando grande parte de seu conteúdo aos sons com maior grau de prevalência. Por exemplo:

Os sons mais prevalentes, como do tráfego ou o de pessoas, comunica o conteúdo menos valioso da informação, entretanto, demanda mais atenção. Eles mascaram os sons informativos que são geralmente mais fracos e menos frequentes. (SOUTHWORTH de 1969, p. 56).

Neste ponto é válido apontarmos que um dos principais, senão o principal livro que possuímos problematizando a questão das paisagens sonoras são Our Sonic Environment e The Tuning Of The World de Schafer. Faremos um breve resumo de The Tuning Of The World, não com o objetivo de aprofundar uma discussão sobre o texto de Schafer, mas apenas referenciar o leitor sobre como Schafer condensa seus conceitos em relação às paisagens sonoras e possui consistências em relação aos pontos tratados por Southworth.

The Tuning Of The World pode ser dividido em:

Parte l: Descrição de paisagens sonoras desde a antiguidade, usando descrições auditivas, inclusive citações bíblicas. Schafer procura estabelecer apontamentos sobre como as comunidades antigas possuíam uma sociedade "aural" contrariamente divergente à sociedade atual, visual.

Parte II: Estudos e apontamentos sobre a produção de sons pós-industriais. Schafer argumenta que o aparecimento de ruídos de baixa frequência e ruídos broadband marcaram uma mudança nos padrões hi-fi e lo-fi das paisagens sonoras em grande parte devido à maquinaria elétrica e industrial.

Parte III: Metodologias para medir e registrar paisagens sonoras. Contém uma lista classificatória envolvendo todos os tipos de ruídos. Existem ainda gráficos e ilustrações demonstrando as mudanças sonoras ocorridas em várias áreas.

Parte IV: Descrição do conceito de uma profissão chamada de Soundscape Designer. Schafer descreve sobre como considera válidas as contribuições para uma melhoria da paisagem sonora, e estabelece uma pedagogia relevante para a compreensão das paisagens sonoras.

As pesquisas contemporâneas na área de paisagens sonoras em grande parte foram influenciadas pelo trabalho de Schafer, entretanto, suas considerações qualitativas de que áreas rurais teriam uma prevalência sobre áreas urbanas Ihe trouxeram questionamentos e críticas que acabam por desvalorizar seu trabalho. De fato, o principal foco de mudança da pesquisa moderna em paisagens sonoras, que iria tornar-se a área conhecida como ecologia sonora, veio dos questionamentos sobre o paradigma dos sons urbanos e sons rurais (TRUAX; BARRETT, 2011, SCHAFER, 1977, WES- 
TERKAMP, 2002). Várias destas pesquisas buscaram questionar a relevância sobre as áreas urbanas como um local de pesquisa, além da preocupação com a recuperação da cidade como um local sonoramente agradável. Arquette (2004) aponta que sonoramente uma cidade não existiria se espelhado em um local agrário. A autora ainda questiona a taxonomia dos sons desenvolvida por Schafer, ou seja, faz crítica às relações entre sons naturais e/ou sons produzidos pelos homens. Nas palavras da autora:

\begin{abstract}
Sobre as minhas dúvidas sobre as descrições de Schafer sobre ambientes urbanos, gostaria de afirmar que o ambiente sonoro, por todo o seu ambiente compactado de baixas frequências, não alcançou um nível de saturação pelo qual nos tornamos alienados dele. Em vez disso, o isolamento ou deslocamento a partir de um ambiente acústico tem uma maior extensão, alcançado devido a aparelhos como o walkman ou os telefones celulares. (ARQUETTE, 2004 p.163) $)^{5}$
\end{abstract}

Arquette argumenta que, em contraste com a perspectiva ecologista de Schafer, o que é crucial na discussão sobre a pesquisa em paisagens sonoras, seria o enfoque nos fatores que fazem o indivíduo se conectar e associar familiaridade ao conteúdo sonoro dos locais. Schafer possui uma perspectiva onde as paisagens sonoras são julgadas como mais agradáveis quando o contato humano é menor ou nulo. Para Arquette, walkmen e telefones celulares entre outros dispositivos móveis são exemplos de contribuintes à alienação, considerando que as pessoas criam seus próprios espaços privatizados, ignorando as sonoridades de um ambiente maior. Estas críticas aos dispositivos móveis e alienação sonora não parecem condizer com trabalhos em criatividade musical (KELLER, 2012), ecocomposição (BARREIRO; KELLER 2004), comprovisações (ALIEL et al, 2015) e música ubíqua que serão amplamente tratados nesta pesquisa.

Truax e Barrett (2011) apresentam conceitos da abordagem lo-fi e hi-fi como: "composição acústica, dinâmica temporal, variabilidade espacial e interações acústicas" (p.1203). Os autores tratam a análise de Schafer, contestada por Arquette, como sendo caracterizada por "sensibilidades auditivas e éticas de um músico", ou seja, os autores sugerem duas vertentes de escuta: uma primeira onde o indivíduo é integrado ao ambiente, e uma escuta voltada às escolhas intencionais, um tipo de processo composicional do qual alguns indivíduos estariam mais adaptáveis à uma condição artística.

5 To return to my above-mentioned misgivings about Schafer's description of the urban environment, I would maintain that the sonic environment, for all its compacted low-frequency ambience, has not reached a saturation level whereby we become alienated from it. Rather, isolation or displacement from an acoustic environment has, to a greater extent, been achieved by gadgets such as the Walkman or mobile phone. 
Arquette (2004) argumenta que os espaços nas cidades são para a vida (social), e que uma alternativa é parar com sentimentos de alienação. As paisagens sonoras nas cidades teriam portanto, uma função social de interligar indivíduos ocupando os espaços.

Não é apenas a mudança da condição rural para a condição urbana, ou uma simples mudança de locação, é uma mudança de ideologia (critérios sociais são mais importante do que fidelidades auditivas) e epistemologia (paisagens sonoras devem "ajudar" espaços, e não ser objetos a serem colecionados), entre outras coisas. (ARQUETTE, 2004 p.165) ${ }^{6}$

\subsubsection{Práticas Ecológicas Hoje}

Encontramos hoje a pesquisa em ecologia sonora sendo utilizada em várias áreas, com os mais variados aspectos. Quase toda a pesquisa contemporânea é baseada em uma única disciplina, uma deficiência que Payne et al. (2009, p.79) identifica como: lacuna da existência de uma pesquisa na área interdisciplinar. Embora existam variações interdisciplinares na literatura voltada aos estudos de paisagens sonoras e meio ambiente sonoro, há uma tendência geral a três características em comum:

- Estudos focados em aspectos exteriores de espaço públicos contra aspectos interiores de espaços privados;

- Metodologias quantitativas - comparação de ambientes;

- Espaços e suas relações sociais e/ou questões de ordem acústica técnica;

Devido a este fator buscaremos algumas teorias ou fontes de pesquisa em ecologia sonora que atualmente busquem ampliar os conceitos até então tratados. Uma das linhas de pesquisa atual trata da análise de forma qualitativa em ecologia musical que se destaca por abranger novos paradigmas, o Grounded Theory.

\subsubsection{Grounded Theory}

O Grounded Theory (GT) é um método de análise científica social com específicos procedimentos sistemáticos. Sua metodologia é voltada a uma abordagem de análise de texto. Um estudo analítico que requer um mecanismo de rastreio e procedimentos passíveis de revisão. Portanto, o analista não faria a interpretação do

6 Not only is the shift from the rural to the urban simply a location change then, it is a shift of ideology (social criteria are more important than aural fidelity) and epistemology (soundscapes should aid spaces, not be objects to be collected), among other things. 
material, mas apenas aumentaria seu nível de abstração para melhorar a sua capacidade de generalização. Há inicialmente a fase de codificação aberta, ou seja, após uma codificação inicial, um complexo conjunto de categorias surge e os primeiros conceitos e categorias são estabilizados. Se for possível detectar um finito número de categorias, os seguintes dados podem ser examinados de forma rápida, considerando um aumento da sensibilidade teórica do pesquisador. Inicia-se uma segunda fase com a tentativa de integrar estes possíveis diagramas categóricos devendo considerar a exploração da falta de conhecimento das interfaces e inadequado conhecimento sobre as ligações entre as categorias e conceitos desenvolvidos. Depois de produzir um diagrama aberto dos dados, a informação é novamente conceituada sobre uma nova ótica. Este processo de codificação e desenvolvimento em diagramas contínuos segue até que o modelo seja saturado, isto é, até que novos conceitos ou categorias não possam ser detectados apesar da adição de material novo (SCHULTE-FORTKAMP; FIEBIG, 2006 p.1).

Segundo Schulte-Fortkamp; Fiebig (2006) o GT tem atraídos estudos específicos sobre ecologia sonora buscando processos não lineares de cunho não cíclico. Em uma abordagem qualitativa são utilizadas entrevistas para considerar uma análise por parte da ótica humana. No experimento dos autores, o principal procedimento foi à utilização de entrevista com moradores em uma rua específica em Berlim tendo em ponto vista as relações de vivência no local e a validação de felicidade em estar neste ambiente, sem a ênfase específica sobre a questão técnica acústica. Tais entrevistas buscaram traçar relações entre a paisagem sonora deste singular local com as relações sociais no ambiente. Neste estudo, os autores analisaram a percepção do som e do ruído e avaliaram os impactos ambientais por meio de questionários não padronizados. $O$ trabalho também examinou os componentes visuais e a exploração da influência que diz respeito à percepção de sons ambientais.

Análises como de Schulte-Fortkamp; Fiebig (2006) demonstraram que ao empregar o GT como forma de compreender os impactos da ecologia sonora no âmbito do contexto sociocultural, as questões vão aquém do impacto acústico como forma geral, enveredando para um contexto da sensação auditiva como importante elemento para esta vertente de pesquisa. Ou seja, perspectivas perceptivas tais como aceitação, expectativa, ajuste, reivindicação, conhecimento e contentamento são relevantes no contexto da avaliação das paisagens sonoras. Esses parâmetros não influenciam através de um discurso individual, mas dependem do social, e do envolvimento cultural da avaliação do indivíduo (SCHULTE-FORTKAMP; FIEBIG, 2006 p.2). Um modelo de percepção foi desenvolvido por Schulte-Fortkamp; Fiebig em um resultado das categorizações padronizadas pelo GT. Tal modelo oferece uma combinação de multiplicidade de resultados derivados a partir da codificação. A estrutura causal-linear e a subdivisão simples (ação, resposta, estímulo) são devidas à dificuldade de descrever 
isso graficamente. Um exemplo diagramático de tal modelo:

Figura 1 - Modelo de Percepção (Schulte-Fortkamp; Fiebig, 2006 p.2)

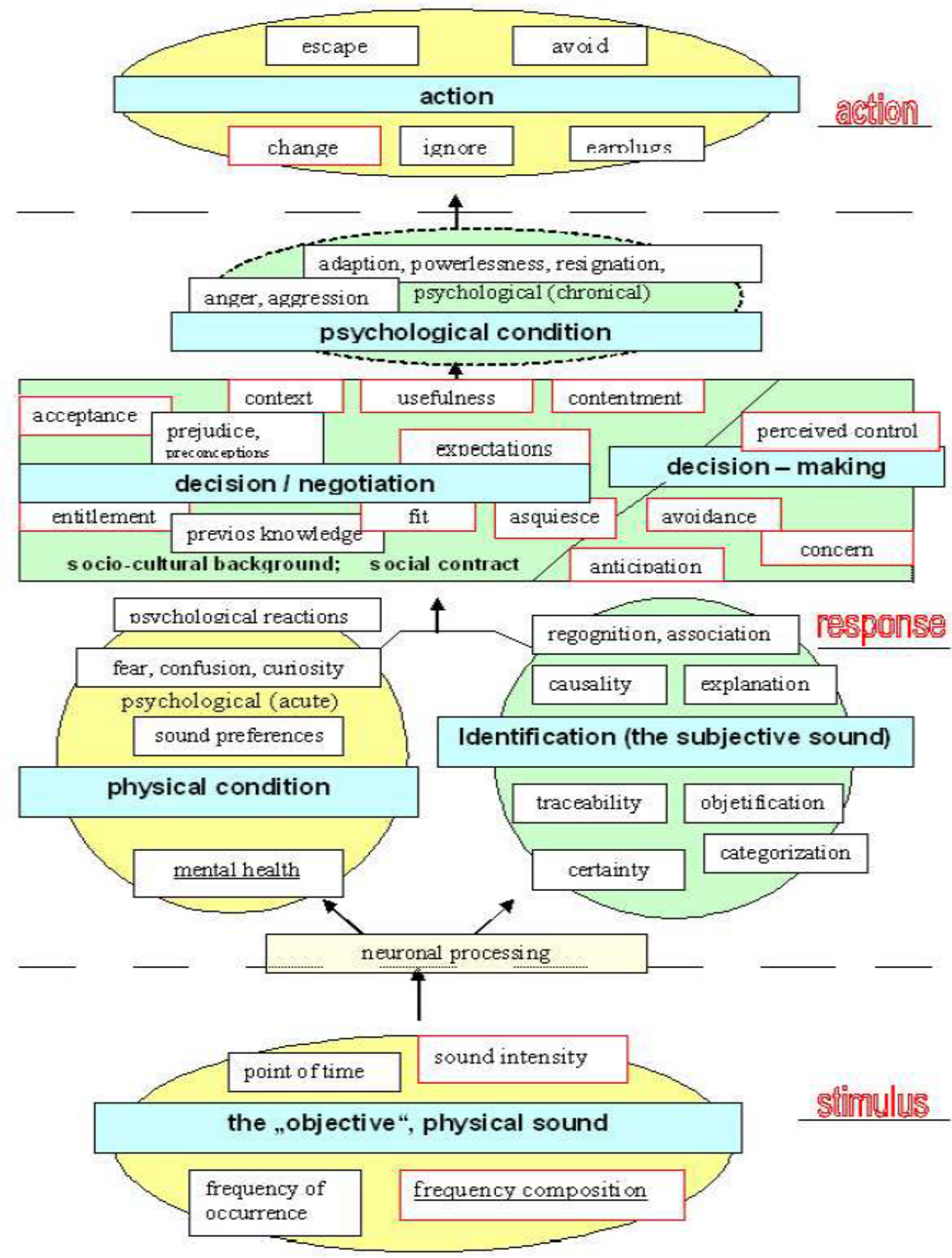

O estudo de Schulte-Fortkamp utilizando o GT como mecanismo de análise de paisagens sonoras não produziu uma teoria com validade ilimitada, generalização e aplicabilidade sem limites. Aparentemente, segundo os autores, existe uma influência nas sensações subjetivas nos ouvintes que afetam as avaliações através do contexto sociocultural. Esta interpretação aponta a importância de uma abordagem qualitativa utilizada neste tipo de estudo. 


\subsubsection{Ecocomposição}

Christian Weisser; Sidney Dobrin são os primeiros a abordar uma preocupação ambiental no campo da composição em seu livro: Ecocomposition: Theoretical and Pedagogical Approaches. Os autores buscam definir e teorizar sobre o que de fato é ecocomposição. Ao assumir as questões ecológicas como meio de investigação teórica e da pedagogia, Weisser e Dobrin procuram atualizar estudos retóricos e de composição, enfatizando as questões "relacionais" e "dialógicas". Os autores compreendem como ecocomposição uma área que "coloca o pensamento ecológico e a composição em diálogo um com o outro, com o intuito de que ambos sejam considerados como propriedades ecológicas da escrita do discurso e as maneiras pelas quais ecologias, ambientes, locais, lugares e naturezas são discursivamente afetados." (WEISSER; DOBRIN, 2001). Entretanto, os próprios autores não afirmam claramente as definições de ecocomposição, desta forma preferem ao invés de afirmar estruturas ou conteúdos abordar práticas condizentes a "entender e praticar" a ecocomposição. Diante desta abordagem dos autores podemos citar ao menos quatro princípios que circundam o conceito de ecocomposição:

1) Fontes de força para um programa que combine os princípios ecológicos com a teoria da composição;

2) As áreas onde há crescimento significativo devem ocorrer por ecocomposição para progredir;

3) Resistência ao pós-estruturalismo;

4) O conceito da necessidade da ecocrítica;

Sobre o quarto ponto, Weisser e Dobrin parecem compreender estes deficiências, dizendo em sua introdução que é "essencial que qualquer um de nós trabalhe em estudos ecocomposicionais podendo estar dispostos a problematizar e auto-reflexivamente criticar essas explorações iniciais em ecocomposição." (WEISSER; DOBRIN, 2001 p.45). Podemos ainda citar trechos do texto dos autores que podem fornecer conteúdos para embasam os princípios da ecocomposicão:

- Estabelecer lugar como simplesmente uma categoria crítica;

- Ecocomposição envolve "lugar como retórica“;

- É a atividade de criar e reagir aos ambientes; 
Desta forma, a ecocomposição é um ponto de partida de investigações teóricas e práticas que envolvam práticas composicionais apoiadas em princípios ecológicos. Problematização de conceitos como local, contexto e ambiente para estudos de composição ainda podem ser desenvolvidos. Este trabalho buscará contribuir para a emancipação deste tipo de abordagem acrescentando questões pertinentes à área sonora.

\subsubsection{Práticas Sonoras à partir de uma Perspectiva Ecocomposicional}

As práticas ecocomposicionais sonoras estão fundamentadas na cognição situada-corporizada (embedded-embodied cognition ${ }^{7}$ )[GIBSON, 1979; HUTCHINS 1995; 2010; VARELA et al, 1992]. Os enfoques situados-corporizados enfatizam o caráter fluido das manifestações criativas (KELLER et al., 2014). As ecocomposições exploram formas de orientar (e de ser guiado) pelos resultados de fenômenos 'emergentes'. "Esses processos podem ser realizados de forma totalmente sonora, porém sempre são afetados em algum nível, aberta ou veladamente, por informações não sonoras, incluindo as qualidades semânticas, espectro-morfológicas, visuais e cinestésicas" (NANCE, 2007: 16).As práticas ecocomposicionais ocorrem através de explorações de recursos ambientais [BURTNER, 2005], incorporando o lugar como fator criativo e destacando a interação com o ambiente como um aspecto central do processo composicional. Além do fator lugar, concebem-se estratégias de troca entre artistas e público que fomentam a interação social. Tais estratégias propõem uma organização aberta do material musical para transformar músicos (NANCE, 2007) e público (KELLER, 2000) em participantes ativos do processo criativo. Ao unir ambiente, músicos e público em experiências estéticas se questiona o paradigma acústico-instrumental centrado na divisão de funções exigida pela criatividade profissional (KELLER et al., 2014a): parte dos envolvidos na atividade criativa não precisam possuir conhecimentos específicos do domínio musical. Desta forma, as abordagens instrumentais podem não ser a melhor opção para incentivar a criatividade. Surge assim a necessidade da procura de métodos para lidar com os recursos materiais locais e com o fomento para a participação ativa do público nas experiências estéticas baseadas nas perspectivas ecológicas. Barrett (2000), Opie (Opie; Brown 2006) e Harris (2007) desenvolveram técnicas de extração de dados para lidar com a complexidade dos recursos locais em atividades musicais. Burtner $(2005 ; 2011)$ explorou o uso de técnicas de síntese em

7 É uma posição filosofia teórica nas ciências cognitivas, intimamente relacionada à cognição situada, cognição incorporada, ciência cognitiva incorporada e teoria dos sistemas dinâmicos. A teoria afirma que o comportamento inteligente surge da interação entre cérebro, corpo e mundo. O mundo não é apenas o "campo de jogo" no qual o cérebro está agindo. Em vez disso, o cérebro, o corpo e o mundo são fatores igualmente importantes na explicação de como determinados comportamentos inteligentes ocorrem na prática. Há preocupações sobre se a EEC constitui uma abordagem nova e substantiva da cognição ou se é meramente uma manifestação de frustração com a abordagem cognitivista clássica. 
ambientes externos como fonte de recursos criativos, propondo o conceito de sóciosíntese. Di Scipio (2008) empregou propriedades acústicas do ambiente como recursos criativos nos sistemas de composição em tempo real. Nance (2007) propôs o uso de partituras sonoras como estratégia para aumentar a abertura dos trabalhos baseados em fontes instrumentais. Cádiz (2012) empregou métodos de síntese por modelagem ecológica no contexto da sua produção orquestral. Basanta (2010) fez uso de técnicas de interação com base ecológica para aumentar o potencial participativo nas suas instalações artísticas. Estas iniciativas contribuíram para a consolidação dos métodos atualmente agrupados como práticas criativas fundamentadas na cognição ecológica ou práticas criativas cognitivo-ecológicas ou ecocognitivas (KELLER et al. 2014). As propostas de Nance (2007) demonstram a aplicabilidade do enfoque ecocomposicional para o caso da co-criação assíncrona entre compositor e intérprete. Porém, Nance não trata da criatividade síncrona e distribuída entre múltiplos participantes.

Observamos nesse amplo campo de atividades, conceitos estritamente voltados à composição musical, não permitindo a implementação de possibilidades criativas e estéticas em uma abordagem improvisada com meio ecológicos. Ao se considerar as conexões entre a improvisação sonora e a ecocomposição, encontramos uma possível relação com o conceito de ecologia criativa (KELLER et al. 2014). Definimos nossa perspectiva levando em conta a "contextualização do comportamento criativo em lugar da dissecção ou compartimentalização dos processos (HELSON,1988:58), situando os produtos criativos tanto como resultado quanto como matéria-prima no ciclo de uso de recursos para a criatividade" (KELLER et al. 2014: 2). Para que uma ecologia sonora viabilize a improvisação sonora é necessário que ambiente, meios e técnicas estejam conectados, permitindo a troca de recursos materiais. Entretanto, esta prática, tenderá a comportar agentes situados em um ambiente sonoro que provavelmente irão alterar esse ambiente. Ou seja, além das ações intencionais dos agentes, existe um processo de auto-organização sonora que gerencia todo o sistema. Esta forma de auto-organização pressupõe que os subsistemas envolvidos são unidades autônomas que geram produtos únicos, dinâmicos e potencialmente inesgotáveis. Desta forma, os agentes interagindo em um habitat comum possuem suas próprias singularidades, propiciando a formação de um ecossistema sonoro.

Entretanto, ao considerarmos o entorno material como ecossistema sonoro acreditamos que a estrutura sonora depende de recursos materiais específicos, vinculados ao conceito criativo de lugar (place). O fator lugar foi introduzido na ecocomposição por Keller; Capasso (2000) e vem sendo aplicado em múltiplos projetos dentro das práticas ecológicas. Como exemplo, consideremos a abordagem de Barbanti, Solomos (2012) e Costa (2014), ao tratar de ecologia sonora: 
pensada em suas relações com a "casa" - oïkos - isto é, o lugar do som na relação com a nossa morada comum, o mundo, e com a nossa maneira de apreendê-lo. Em outras palavras: a relação som-mundo. $\mathrm{Na}$ ecologia sonora, não se trata "simplesmente" de uma questão de incômodo ou de poluição, mas do lugar do som em relação a nós mesmos, ao outro e ao contexto global ao qual nós pertencemos. $\mathrm{O}$ mundo, precisamente (BARBANTI apud SOLOMOS, 2012: 168).

Neste quadro, Solomos apresenta o mundo (ou sistema) como forma de ecologia sonora em relação ao indivíduo, que no contexto desta discussão é equivalente ao agente que realiza atividades criativas. A partir desta ótica as ações de todos os envolvidos em obras artísticas oriundas de uma ecologia sonora terão impacto no entorno local. No entanto, é necessário delimitar o entorno (lugar) tanto no tempo quanto no espaço. Neste caso, não estaríamos tratando de entornos e ambientes passivos - como é o caso das propostas da paisagem sonora (WESTERKAMP, 1989)mas de nichos sonoros (KELLER, 2012). Desde a perspectiva ecológica, os nichos sonoros abrangem a ação dos agentes e as potencialidades dos recursos materiais que fornecem a base para diversos processos de auto-organização observados nas práticas artísticas.

De forma geral, neste trabalho entendemos a ecologia sonora como a subjetividade sonora de lugar (um local específico, um grupo, um som biológico) captada através percepção de cada agente contido neste sistema. Este sistema se torna complexo a cada ciclo onde os agentes percebem os recursos materiais e cognitivos, analisam suas possibilidades de interação e sintetizam ações que alteram o entorno que se adapta regularmente para proporcionar um novo ciclo. Consideramos significante apontar que toda forma de perspectiva ecológica possui primordialmente um contexto caótico e de imprevisibilidade intrínseco que pode vir a causar mudanças significativas no sistema. Neste contexto geral, consideramos que toda forma de imprevisibilidade poderá ser conceituada como uma contingência no sistema, que em nossa condição sonora será determinada pela capacidade de improvisação dos agentes. São as tomadas de ação e retomadas de reação que poderão causar ciclos sonoros vastamente divergentes que irão transformar o sistema drasticamente. 


\section{Comprovisação}

A comprovisação será utilizada devido aos diversos trabalhos em áreas composicionais que utilizam das práticas ecológicas, mas que mantinham as propostas de improvisação fora de conjectura. A comprovisação neste sentido surge como uma ferramentas que pode criar conexões entre a improvisação sonora com as práticas ecológicas que tem uma ênfase composicional. Consideramos válida a tentativa de estabelecer um quadro conceitual para as práticas criativas que ficam a meio caminho entre as propostas de improvisação livre (ALIEL et al. 2015; COSTA 2014) e as práticas ecológicas composicionais que visam a mais completa determinação dos eventos sonoros. Parece-nos primordial o desenvolvimento de uma estrutura que possa interligar a estabilidade composicional e dinamicidade da improvisação sonora. Considera-se neste trabalho a prerrogativa de ecologia sonora como estruturas compostas e préestabelecidas permitindo diversas contingências que alteram os parâmetros do sistema. Diversas destas alterações podem advir de eventos imprevistos e/ou da capacidade de adaptação dos indivíduos no ambiente. Desta forma, compreendemos a comprovisação como um mecanismo capaz de proporcionar a adaptação dos agentes em sistema composto ou rígido.

O termo comprovisação ainda não possui uma clareza em sua definição nem uma origem bem definida, entretanto usaremos como referência propostas como as de Fujak (2011), Hannan (2006), Bhagwati (2014) Dunas (2010) e Mailman (2013) em um sentido que nos parece condizente às necessidades deste projeto.

\subsection{FUJAK (2011)}

Em um manifesto elaborado por um grupo de artistas eslovacos, Fujak (2011) propõe uma definição ampla com o propósito de emancipar e legitimar as práticas comprovisatórias. São levantados alguns pontos que, para tal grupo são relevantes para uma estética comprovisatória:

- O princípio que articula em seus métodos a arte contemporânea transversal em analogia às situações de vida de forma transparente (como resultante do que é rigorosamente planejado e do que está sujeito a mudanças imprevisíveis, para as quais devemos responder operacionalmente e criativamente);

- A escolha consciente das mutações em processos composicionais como os antecedentes, os princípios, as diretrizes e a improvisação situada no contexto contemporâneo de intertextualidade musical com recursos tecnológicos; 
- O conceito que expressa o processo de tornar o ato criativo, o gesto artístico e sua percepção numa ação unificada (W. WELSCH, 1992 apud FUJAK, 2011);

- Avanço no processo de re-territorialização artística lidando com o que/como e porque somos o que somos (G. DELEUZE, 1980, apud FUJAK, 2011;

- Algo que também pode ser encontrado no espaço entre diferentes meios artísticos em tempos da desaparição do pós-modernismo (que refuta os preconceitos de "pureza formal" e da separação entre forma e conteúdo), em música, artes visuais, cinema, dança, teatro, arte-performance, happenings, literatura, fotografia, vídeoarte, etc;

- Algo que define a abertura no espírito das metáforas de bricolage, imagemsônicas e texto-gesto como espaço aberto e tolerante, mas definindo as coordenadas da música e da arte multimídia de forma radicalmente não convencional;

- Uma das oportunidades para a transgressão da esfera AMA (som, música e artes audiovisuais) nas poéticas da Transmusic Comp, Snow-u, e os Cantos da Floresta que - no início da segunda década deste século e sem pretensões de serem estéticas da comprovisação - reatualizam a cena artística eslovaca.

\subsection{HANNAH (2006)}

A fim de estreitar as definições metodológicas, nos apoiamos nos relatos dos processos criativos de Hannan (2006) que afirma ter adotado o termo comprovisação (comprovisation) como denominação para composições que utilizam gravações de práticas improvisadas. Ele sugere que embora existam diversos elementos aleatórios ou intuitivos, a comprovisação seria uma nova forma de se pensar a composição. Hannan (2006) define alguns parâmetros para caracterizar a prática da comprovisação:

- A intenção explícita de propósito: mesmo que a ideia geral seja tentar criar novos materiais para a composição por meio de processos improvisatórios ou através da experimentação de formas livres de montagem do material, Hannan sugere que deve existir uma formulação explícita do propósito, podendo ser modificada se for julgada como ineficaz;

- A análise aprofundada da literatura: é necessário estar ciente da literatura escrita e gravada, incluindo as técnicas instrumentais não tradicionais e as técnicas da improvisação livre;

- A adoção da metodologia de pesquisa: o projeto deve ter a capacidade de explicar as escolhas e todas as relações estruturais entre os movimentos, seções, e frases. No caso das obras comprovisadas, a perspectiva experimentalista pode 
ser descrita como um tanto arbitrária e não-sistemática. No entanto, há aspectos do enfoque experimental que mostram proximidade com a prática comprovisatória.

- A relevância sistemática e abrangente de dados musicais: por exemplo, através da montagem de uma biblioteca de eventos de som para viabilizar o trabalho criativo;

- A apresentação pública dos resultados visando uma avaliação mais aprofundada (reprodutibilidade): O processo crítico dos produtos musicais pode estabelecer uma contribuição única para o conhecimento compartilhado. Reprodutibilidade é outra questão.

\subsection{BHAGWATI (2014)}

Desde outra abordagem, podemos citar o trabalho de Bhagwati (2014). O autor despendeu questionamentos sobre a notação musical como recurso para obras fechadas e abertas em fluxo contínuo, visando resultados estéticos parcialmente estruturados. Porém, Bhagwati não se limita a desenvolver ou estabelecer propostas puramente formais para as obras comprovisadas. Como requisito para desenvolver trabalhos que possam abranger as práticas da composição e da improvisação no contexto orquestral, Bhagwati (2014: 171) propõe a "perspectiva da notação", que serviu para estruturar os elementos reproduzíveis (composição) e contingentes (improvisação) em oposição ao que ele denomina de "perspectiva da audição centralizada". Esta última abrange a estruturação hierárquica da prática musical através da sincronização polifônica - geralmente envolvendo a organização métrico-tonal - e centralizando as decisões interpretativas na figura do regente. Na perspectiva centralizada, o objetivo não seria o equilíbrio entre os fatores contingentes e determinísticos, mas o efeito dramático ou narrativo viabilizado pela organização cronológica da estrutura formal. Bhagwati busca no recurso da notação musical um possível mecanismo de controle entre composição e improvisação capaz de unir as duas atividades. As "perspectivas da notação" propiciam uma ponte entre a "composição fixa" e a "improvisação livre", tornando evidente o que todo músico experiente sabe: que nenhuma composição se destina a ser livre de contingências - assim como nenhuma improvisação abandona completamente as estruturas reproduzíveis. Levando esse raciocínio ao extremo, segundo Bhagwati toda criação musical pode ser vista como comprovisação. Para o autor, três modelos parecem dominar as práticas comprovisatórias:

1) Variações com dramaturgia plana: utilizam fórmulas melódicas/harmônicas ou ciclos rítmicos estáveis;

2) Formas "livres" de crescimento orgânico e/ou de desintegração gradual; 
3) Composições com improvisações incorporadas, por exemplo, improvisações com seções compostas em blocos;

É interessante observar que essas três categorias podem ser exemplificadas por estratégias composicionais utilizadas em perspectivas criativas surgidas no século XX. As metáforas orgânicas foram introduzidas por Varèse na sua proposta de abertura formal baseada em processos sonoros, envolvendo agregados sonoros que eram estruturados por mecanismos emergentes (bottom-up), como exemplificado na comparação entre o conceito de timbre e o processo de formação de cristais (WENCHUNG e VARÈSE, 1966). A stasis, ou organização plana de elementos formais, foi claramente exemplificada nas obras de Feldman (1989). Feldman utiliza a metáfora da tela (canvas), comparando o processo composicional ao procedimento utilizado pelo pintor. Ao colocar múltiplas camadas de tinta, as cores vão sendo modificadas lentamente. Musicalmente, o efeito é a suspensão da percepção do tempo, por conta da expansão dos processos de organização sonora a escalas que vão além da capacidade de comparação entre os eventos locais. A forma emerge sem necessidade de impor estruturas narrativas. A terceira estratégia, a organização por blocos, foi amplamente explorada pela escola Polonesa dos anos 1960. Neste caso, podemos descrever o procedimento como de-cima-para-baixo (top-down): as relações temporais entre seções tomam precedência sobre as relações temporais entre eventos. Em particular, Lutoslawski (1959-1960) aplica técnicas improvisatórias dentro de obras estritamente estruturadas desde o ponto de vista da proporção temporal entre as seções. A escrita em bloco foi posteriormente adotada por múltiplos compositores dentro do repertório orquestral.

Bhagwati (2014) nos proporciona importantes insights sobre abordagens alternativas para lidar com contingência e controle:

1) Abandono da centralização sônica ("a mistura ideal"), espacial ("o palco italiano") e metodológica (a notação determinística) em favor de múltiplas perspectivas de escuta não homogêneas;

2) Elaboração de uma polifonia de práticas comprovisacionais que permitem camadas (layerings) horizontais de eventos sonoros, portanto, uma multiplicidade de relacionamentos heterofônicos, não só entre as diferentes "vozes" ou fontes sonoras, mas entre os diferentes parâmetros musicais dentro de cada camada sonora;

3) Elaboração dos múltiplos níveis da estrutura como um fluxograma de opções em que as decisões podem resultar em diversas formas de participação dos músicos, abrangendo: a interação sonora ou visual com seus pares e/ou com 
vários regentes, o "significado" musical ou estilístico a partir da referência a uma forma externa (musical, poética, matemática ou de outra natureza) ou a partir do resultado de um processo autônomo ou interativo;

4) Perspectivas consolidadas: manter ou mesmo expandir os benefícios do uso da narrativa dramatúrgica e da estrutura formal (composição determinística), bem como a incorporação de elementos interativos dentro do uso de fluxogramas procedimentais - o regente como co-criador;

\subsection{DUDAS (2010)}

O último item faz referência às propostas vinculadas ao suporte tecnológico para viabilizar mecanismos de mediação entre músicos e ferramentas. Numa primeira aproximação ao problema, Dudas (2010) introduz os fatores tecnológicos dentro da prática comprovisatória e propõe dois modelos que complementam os fatores citados por Bhagwati:

1) Compor para um "instrumento", podendo ser utilizado na improvisação em uma performance;

2) Improvisar com ferramentas tecnológicas, a fim de criar materiais pré-composicionais;

Os aspectos da comprovisação em ambos os cenários são demarcados pelas limitações das ferramentas utilizadas, tanto em hardware quanto em software. Segundo Dudas, a definição do "instrumento" também incluiria as estruturas composicionais, mesmo quando o instrumento é utilizado em práticas improvisacionais [Dudas, 2010: 29]. Desta forma, teríamos as denominações de "improvisação estruturada" ou "composição improvisada". Cobussen (2003) sugere que improvisadores poderiam pressupor todo tipo de objetos, estruturas entre outros apetrechos com uma finalidade utilizável (sonoramente) no ambiente como fontes de suas experiências sonoras. Como vem sendo colocado nos múltiplos projetos embasados em cognição ecológica [BURTNER, 2005; KELLER, 2000; KELLER et al. 2010], a proposta é que a ecologia dos materiais seja utilizada em prol da ação criativa. Por exemplo, quando um improvisador observa/escolhe uma cadeira, essa escolha pressupõe a limitação das ações em função das suas experiências prévias com cadeiras como recursos sonoros. Nesse contexto tem impacto não só as possibilidades sonoras do objeto. Também tem um papel, as crenças - ou vieses criativos - do participante. Ou seja, ele poderia tratar a cadeira como objeto percussivo, poderia criar sons contínuos com a mesma, e poderia até mesmo utilizá-la para ter acesso a outros objetos que ficariam fora do alcance sem o auxílio da cadeira. Seu conhecimento prévio sobre o objeto "cadeira" permite as 
affordance $^{8} s$ ou os canais de interação materiais - fornecendo informações de como agir para obter resultados sonoros.

A discussão precedente deixa claramente estabelecida que a comprovisação não é um fenômeno novo, mesmo que ainda não haja um trabalho teórico sistemático que possa dar conta das múltiplas nuances dessa prática. Tendo em vista as propostas pioneiras de Hannan (2006), Dudas (2010) e Fujak (2011), a postura de Mailman (2013) de se auto-definir como um dos pioneiros dessa vertente é no mínimo questionável.

\subsection{MAILMAN (2013)}

Mailman considerar "a comprovisação como um tipo de criatividade musical que se relaciona à composição e à improvisação de uma forma sem precedentes, algo que era impossível de se alcançar com tecnologias mais antigas" (MAILMAN, 2013: 357). Mailman defende que a comprovisação se torne uma ferramenta significativa somente quando apoiada em processos interativos. A diferença entre a comprovisação e a composição interativa (CHADABE, 1983) seria o controle da expressividade do sistema (MAILMAN, 2013: 358). A comprovisação separaria os dados gerados algoritmicamente em características de nível macro (propriedades emergentes) e trajetórias expressivas que seriam manipuladas pelo performer. $\mathrm{O}$ executante pode expressar-se com seus movimentos, sabendo exatamente de que forma suas trajetórias podem afetar os resultados. Segundo Mailman, as técnicas de geração algorítmica devem ficar limitadas a processos quase-estocásticos, amplamente explorados desde os anos 1960 (XENAKIS, 1971). Dada essa definição restritiva, o autor postula os seguintes pontos como requisitos para a comprovisação:

1) A comprovisação envolve compor música gerada a partir de algoritmos;

2) Envolve intencionalidade e manipulação de parâmetros através de movimentos, visando à expressividade.

\subsection{Considerações Sobre as Propostas Comprovisatórias}

Enxergamos uma posição aberta no manifesto proposto por Fujak (2011), visando buscar dar validade a uma linha da arte sonora contemporânea que já se expõe em diversas obras que ainda não têm uma denominação comum. Dentro das diversas formas de compreender a comprovisação, podemos concluir que esta prática vai além

8 É a possibilidade de uma ação em um objeto ou ambiente. Embora se tenham desenvolvido significados adicionais, a definição original em psicologia inclui todas as ações que são fisicamente possíveis. Quando o conceito foi aplicado ao projeto, ele também começou a se referir apenas às possibilidades de ação. 
de uma combinação de composição com improvisação, tendendo a se tornar um mecanismo com regulação própria. Os procedimentos comprovisacionais têm adquirindo motivação própria, oriunda da fusão de processos transversais da arte contemporânea, abrangendo arte sonora, visual e performance (FUJAK, 2011). Entre os exemplos apresentados, em destaque: a manipulação de objetos gravados a partir de conteúdos improvisados (HANNAN, 2006), a utilização de técnicas variadas de notação musical com intuito de obter materiais fechados, regulados ou organizados hierarquicamente (composição determinística) e materiais abertos, estocásticos ou heterofônicos (improvisação) (BHAGWATI, 2014). A prática comprovisatória também inclui procedimentos auxiliados pelo suporte computacional, incluindo estéticas vinculadas à arte interativa que adotam enfoques embasados na tradição instrumental (DUDAS, 2010) e nos ideais românticos de expressividade e virtuosismo cultivados durante o século XIX (MAILMAN, 2013) ou a adoção da intencionalidade como base do processo de organização sonora (HANNAN, 2006; MAILMAN, 2013).

Consideramos relevante uma breve discussão crítica sobre a comprovisação. De fato, não há ainda uma clara definição de como a comprovisação pode de fato impactar ou contribuir na área da ecologia sonora. Abordaremos o conceito de comprovisação como uma tentativa recente de estabelecer um quadro conceitual para as práticas que ficam a meio caminho entre as propostas de improvisação livre (ALIEL et al. 2015; COSTA 2014) e as práticas composicionais que visam a mais completa determinação dos eventos sonoros.

Consideramos a comprovisação como um caminho para tentar desenvolver metodologias em trabalhos na área de ecologia sonora que envolvam composição e práticas de improvisação, lidando com questões relacionadas ao imprevisto ou ao inesperado. Neste procedimento metodológico, ainda que lidemos com diretrizes controladas (composições) e contingenciais (improvisações) que foram desenvolvidas através de vários procedimentos, a comprovisação parece implicar numa forma específica de produção artística que extrapola a mera combinação entre improvisação e composição e vice-versa. Em trabalhos como Destino Pirilampo (ALIEL; FORNARI, 2013), Citações (ALIEL et al, 2015), Lyapunov Time (ALIEL, 2016) e The Maxwell Demon (ALIEL et al, 2016) encontramos um quadro onde parte das propostas são préestabelecidas de forma restrita não permitindo modificações (algoritmos, fluxogramas de opções, procedimentos regulados e fixos) e ao mesmo tempo observamos aspectos mais abertos relacionados à imprevisibilidade, ao erro e a ações não controladas e inesperadas. Estes recursos relacionados às tomadas de decisão criativas em tempo real remetem à improvisação (os trabalhos citados serão discutidos no capítulo VI).

Este tipo de proposta originou-se de desdobramentos de práticas artísticas apoiadas em temas ecológicos, tais como a composição de paisagens sonoras e a 
ecocomposição citadas anteriormente. Este desdobramento investiga os problemas relacionados à utilização de materiais ambientais em material improvisatório. Devido ao alto grau de imprevisibilidade observada neste tipo de ambiente sonoro (ALIEL et al, 2016), ou seja, considerando as ações de agentes e/ou as potencialidades dos recursos ambientais para auto-organização em práticas artísticas, encontramos nesse tipo de material um conteúdo vasto para trabalhos comprovisacionais. Citaremos as principais hipóteses de estruturas que serão utilizadas em propostas artísticas neste trabalho:

- Elaboração de uma polifonia sonora em camadas (layerings) - (BHAGWATI apud ALIEL et al, 2015) - em nossos estudos, as camadas de fonte sonora compreendem, tanto ações acústicas como eletrônicas, promovendo condições para a criação de uma variante das paisagens sonoras tradicionais (metasoundscape, ALIEL; FORNARI, 2013);

- Elaboração de fluxogramas de opções como recurso composicional - (BHAGWATI apud ALIEL et al, 2015) - em nossos estudos, abordamos o recurso dos fluxogramas de opções como recurso composicional e improvisatório que incluem procedimentos específicos (cada comprovisação proporciona uma variante de fluxograma, proporcionando duas ou mais opções de escolhas) com determinadas condições, promovendo resultantes completamente variantes das iniciais. São considerados ainda ações imprevisíveis para atingir tais variantes como o erro (ver Citações , $L Y T$ ), ou interações independentes de múltiplos agentes e recursos ambientais em um nicho sonoro;

- Construção de ferramentas tecnológicas para improvisação - (DUDAS apud ALIEL et al, 2015) - Buscamos desenvolver algoritmos computacionais que permitam certa liberdade artística improvisatória. Inicialmente, desenvolvemos nossas ferramentas tecnológicas em plataformas de criação como o Pure Data. Temos trabalhado também com a inclusão de ferramentas tecnológicas móveis (celulares e tablets) que estão sendo testadas e adaptadas para este fim (vide Citações , TMD). Há ainda a preocupação de integrar socialmente uma maior gama de indivíduos. Ou seja, as ferramentas desenvolvidas não priorizam músicos profissionais. Há todo um esforço para que estes recursos sejam acessíveis para indivíduos não musicalizados, o que proporciona uma maior imprevisibilidade no ambiente devido à integração de muito material original, conforme sugerido no Modelo Dentro-Fora (FERRAZ; KELLER 2014, vide capítulo V). Estas questões estão intimamente relacionadas aos métodos determinísticos e indeterminados, ou seja, o processo de tomada de decisões nos ciclos criativos. 


\subsection{Discussões sobre Comprovisação na Ecologia Sonora}

Diante da premissa defendida no capítulo I onde compreendemos a ecologia sonora como a subjetividade sonora de um lugar captada e interpretada pela percepção dos agentes, neste tópico alinhamos os conceitos da ecologia sonora com a comprovisação, justificando sua escolha com intuito de permitir o implemento de estruturas improvisadas em unidades ecológicas.

Fujak (2011) defende que a comprovisação deveria ser atingida via metáfora associativa à vida. Nesse aspecto, o autor defende que na vida, (em um viés biológico) cenários podem ser planejados, mas eventos de maiores e menores instâncias podem alterar estas condições. Nesse segmento, podemos conjecturar que ações, interações, reações e até mesmo eventos indeterminados (imprevisíveis) possam ocorrer, propiciando transfigurações significativas nos planos de um indivíduo. Os planos seriam portanto formas de projetar métodos, recursos (materiais e cognitivos) e atividades em eventos. Em uma expansão à metáfora da vida, como proposto por Fujak, sugerimos as abstrações de planos que se subdividem em duas vertentes principais: os planos de diretrizes e os planos de contingências (ALIEL et al, 2016). Em planos de diretrizes se encontram as regras, as ações previstas, os algoritmos, os métodos e os recursos imutáveis pré estabelecidos em tempo diferido. Em música: a composição. Os planos de contingências são as imprevisibilidades, o acaso, às eventualidades e possivelmente o caos e ações aleatórias. Os métodos e os recursos são mutáveis, estabelecidos no tempo real. Em música: a improvisação. Os dois planos podem abranger variadas formas de entrosamento, sendo suscetíveis à idiomas musicais ou caracteristicas culturais.

Em uma abstração da ecologia sonora orientada pela comprovisação, compreendemos que os eventos devem se combinar de forma a não existir uma distinção objetiva do que é diretriz e do que é contingência. Por exemplo, um agente pode planejar uma interlocução sonora entre instrumentos acústicos e sons ambientais. Neste contexto, o agente pode criar todas as diretrizes do contexto do instrumento acústico, mas não poderá estar ciente das contingências sonoras recorrentes dos sons ambientais. Não há como pressupor quais e quando os sons serão executados. Neste premissa, encontramos um quadro onde o agente segmenta os planos de forma drástica, classificando uma configuração direta ao plano de diretrizes e uma configuração indireta ao plano contingencial.

Acreditamos que para a existência relevante de uma ecologia sonora em um viés comprovisatório são necessárias medidas que diluam os planos de atuação em uma proposta homogênea. Partindo do exemplo citado anteriormente, pode-se adicionar fluxogramas de ações, como proposto por Bhagwati (2014) na escrita dos instrumento acústicos, propiciando momentos de contingências mais ou menos abertas. E/ou ainda 
adicionar registros gravados de sons ambientais ao local, intuindo construir diretrizes contrastantes ou similares as contingências presentes.

Há ainda um fator preponderante que pode ser adicionado ao sistema que são os eventos caóticos ou aleatórios. Neste segmento, os processos estocásticos são percebidos tanto em condições de ecologia sonora quanto em uma analogia à vida e parecem proporcionar o principal recurso gerador de comprovisações que unifique os dois planos de abstrações. Sugerimos pensar em eventos caóticos como condições existentes em todos os sistemas, possibilitando transformações que variam de mínimas à drásticas. Mantendo o exemplo citado, o agente pode adicionar percursos mais ou menos aleatórios no fluxograma de ações propiciando transformações em várias camadas. Um algoritmo aleatório pode ser utilizado para disparar registros de sons ambientais gravados e/ou processados em tempo real. Estas funções estocásticas possibilitam eventos singulares que não podem ser amplamente previstos e raramente são repetidos, entretanto, apresentam uma estrutura metodológica que permite objetos mensuráveis, testáveis e replicáveis.

Embora viável, este estado de ecologia sonora comprovisada produz um sistema complexo auto adaptável. Assim, nos parece necessário uma formalização de sua modelagem para embasar suas propriedades, relações e recursos qualitativos e quantitativos. 


\section{Modelagens de Sistemas Socioecológicos Adaptáveis - Formalização para Comprovisações em Ecologia Sonora}

O capítulo IV aborda formalizações e práticas em ecologia sonora quando estas abordam condições de composição e improvisação sonora. Utilizamos como referência trabalhos em sistemas complexos adaptáveis devido às variáveis que podem ser observadas neste tipo de abordagem que parecem trazer componentes relevantes a estudos artísticos deste porte. As modelagem sócio-ecológicas foram desenvolvidas para projetar performance/experimento ${ }^{9}$ que serão conduzidas como estudos de caso. Desta forma, podemos fazer apontamentos análiticos de processos, interações, tipos de agentes e procedimentos relevantes ou descartáveis.

Os sistemas sócio-ecológicos são considerados como sistemas adaptativos complexos que se caracterizam por auto-organização e controle distribuído. Eles abrangem múltiplos agentes com interesses e objetivos de gestão diversos e contrastantes, agindo em diferentes níveis espaciais e temporais (REED, 2008; PAHL-WOSTL, 2007; GIAMPEITRO, 2002). Em tais sistemas, os processos sociais e ecológicos entram em múltiplas formas de interação variando os níveis de organização. Estas reorganizações dão lugar a estruturas e funções emergentes.

Diversas áreas do conhecimento vem desempenhando melhoras em entender como funcionam os sistemas complexos. Rotmans e Asselt (1996) definem que discutir sistemas adaptativos complexos traz um teor participativo que investiga o combinar, interpretar e comunicar entre conhecimentos de diversas disciplinas científicas. As abordagens para avaliar as respostas dos sistemas adaptativos complexos a cenários de mudança têm sido comumente usadas para projetar estratégias de desenvolvimento e gestão sustentável. Normalmente estas abordagens têm se baseado em processos de modelamento. Diversos modelos podem ser desenvolvidos para observar sistemas socioecológicos. Utilizaremos os princípios sugeridos Sibertin-Blanc et al (2011) para determinar processos qualitativos em sistemas adaptativos complexos que parecem se alinhar aos estudos de uma ecologia sonora comprovisada.

Através de um plano geral sobre sistemas adaptativos complexos sugeridos por diversos autores, incluiremos duas modelagens que podem contribuir com a pesquisa em ecologia sonora comprovisada e que serão a base da construção dos estudos de caso desta dissertação. Iremos apresentar e utilizar a Proposta de Modelagem de

9 São atividades desenvolvidas para existir em duas condições: 1) como performance em obras artísticas. 2) experimentos capazes de gerar dados que podem ser analisados, catalogados, comparados e testados. (ALIEL, et al 2017) 
Síntese Ecológica (PMSE) (KELLER, 1999) e a Proposta de Modelagem em Looping (PL) (ALIEL et al. 2016). Estes modelos serão baseados em metodologias específicas (descritas nos próximos tópicos) ao assunto.

\subsection{Um Meta-modelo de Entidade-Processo}

Trabalhar em um ambiente interdisciplinar, multi sonoro e com variados tipos de agentes requer uma estrutura conceitual partilhada para uma interpretação coletiva dos conceitos apresentados uns pelos outros. Assim, nossos modelos serão caracterizados como meta-modelos (SIBERTIN-BLANC et al., 2011). A principal função do metamodelo é fornecer uma estrutura formal que facilite a descrição coerente dos sistemas socioecológicos como modelos formais. O meta-modelo identifica os tipos de elementos constitutivos que são considerados na concepção dos modelos socioecológicos e como eles estão relacionados.

De acordo com os meta-modelos propostos por Sibertin et al (2011), um modelo socioecológico inclui um conjunto de entidades e um conjunto de processos, juntamente com as relações entre elementos desses conjuntos. A estrutura do sistema é composta por entidades e relações entre entidades, sendo ambos perceptíveis e mais ou menos persistentes (pregnantes). O caráter dinâmico dos sistemas socioecológicos são tratados através de processos que envolvem uma ou mais entidades no sistema, fazendo com que o estado e também a estrutura do sistema evolua para uma condição mais ordenada ou caótica. Finalmente, consideramos as interações entre um sistema socioecológicos e seu entorno ambiental.

\subsection{Estrutura do Sistema: Entidades e Relações}

Os meta-modelos distinguem três categorias de entidades: recursos materiais, recursos cognitivos e agentes ${ }^{10}$. As interrelações entre esses três tipos de entidades produz as instâncias de entidades, que são os recursos individuais considerados imprescindíveis que podem aparecer ou desaparecer ao longo do tempo (pregnância), ou experimentar mudanças de estado. As entidades são caracterizadas por propriedades cujos valores constituem o estado de uma instância ${ }^{11}$. Eles são dotados de operações que processam esses valores de propriedade. Existem dois tipos de relação entre entidades. Uma relação permanentemente estrutural associada às relações por sua

10 No original de (SIBERTIN-BLANC et al., 2011) atores. Entretanto, consideramos que nomenclatura de agentes é mais coerente com os pressupostos ecológicos.

11 O termo advém da programação computacional. O conceito de instância condiz com a existência de um objeto que compartilha as mesmas características de classe com outro indivíduo ou objeto. Por exemplo: Música, embora exista um grupo geral que determina música, existem diversos estilos e formas variantes. Podem possuir mais ou menos similaridade. 
própria natureza e uma relação não-estrutural, aquela que coloca em associação às entidades como resultado de alguma ação.

Figura 2 - Um meta-modelo para a modelagem formal de sistemas socioecológicos.

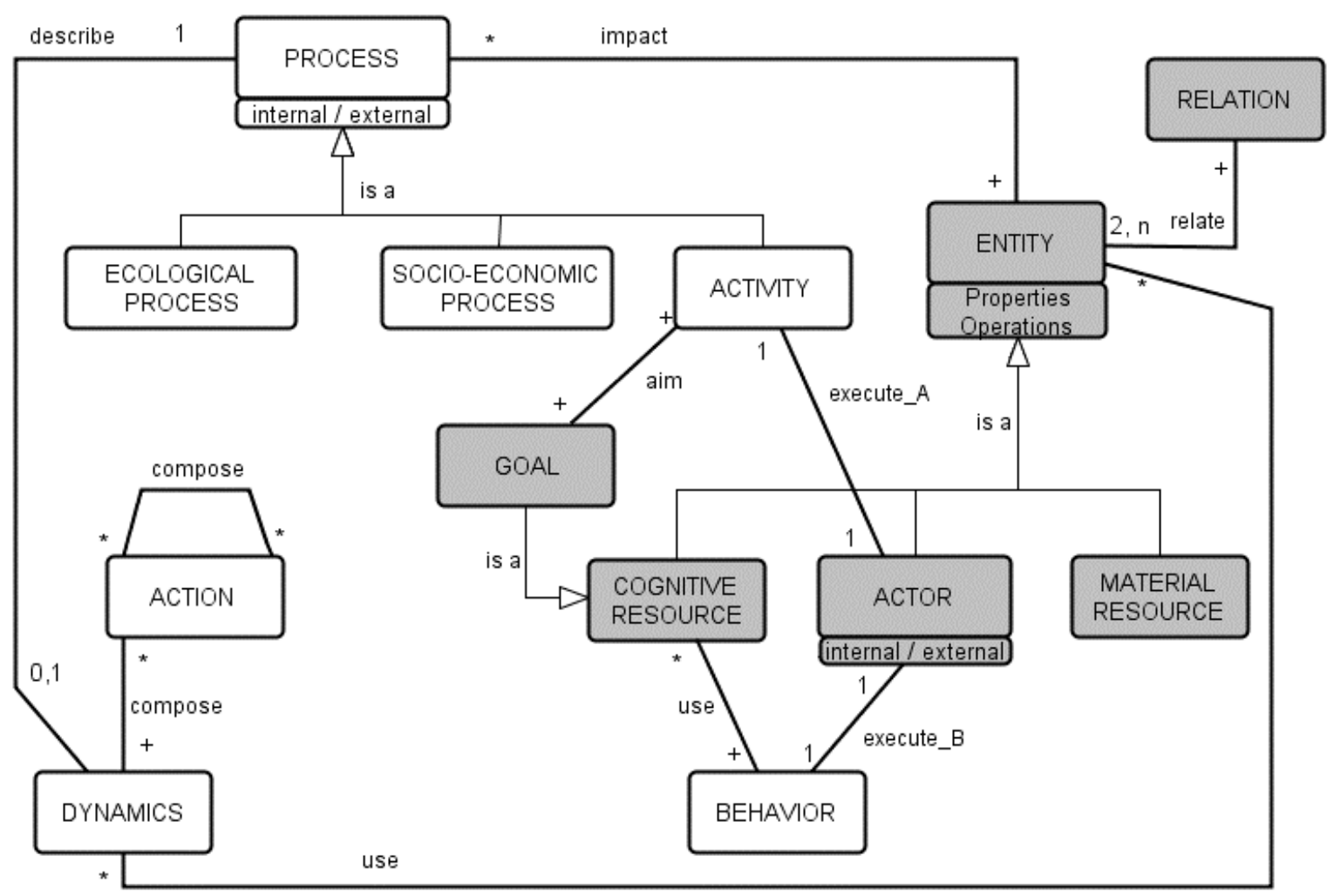

Assim podemos definir:

1) Os agentes: são um indivíduo, uma população de indivíduos semelhantes (ou não), um grupo, uma organização, uma hierarquia. Cada agente executa pelo menos uma atividade.

2) Os recursos materiais: são objetos de uso ou objetos para uso. Os recursos materiais são recursos físicos espacialmente e temporalmente distribuídos (por exemplo, um corpo de água, um instrumento musical, um celular).

3) Um recurso cognitivo: é válido para um único agente ou compartilhado por vários. Muitos recursos cognitivos têm uma contrapartida material que, na maioria das vezes, não é relevante considerar. Deve-se enfatizar que qualquer conhecimento sobre um recurso material usado por um agente ou um processo implica na existência de um recurso cognitivo próprio. Tal recurso cognitivo será considerado no modelo somente se necessário (por exemplo, se suas propriedades não 
correspondem às do recurso material). Cada recurso deve ser impactado ou usado em ao menos uma atividade.

Aponta-se que a cada momento, a estrutura de um sistema complexo adaptável é definido como os conjuntos de suas instâncias de entidade e de seus vínculos

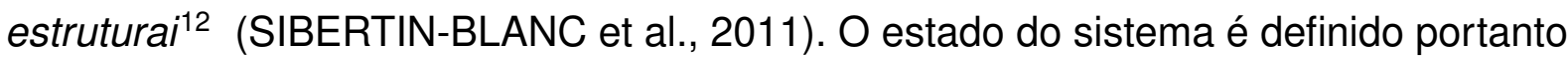
como os estados dessas entidades (os valores de suas propriedades) juntamente com os vínculos não estruturais existentes.

\subsection{Sistema Dinâmico: Processos e Comportamentos}

Os processos são as resenhas geradas em sistemas socioecológicos, estes fenômenos permitem uma observação sobre as transformações recorrentes. Cada execução de um processo impacta as entidades alterando seus valores de propriedade ou criando ou destruindo instâncias de entidade ou vínculos.

Distinguimos três tipos de processos: processos sociológicos ${ }^{13}$, processos ecológicos e atividades:

- Um Processo Ecológico corresponde a uma promulgação de uma lei biofísica. Ele determina a evolução dos estados de recursos materiais (e possivelmente de agentes).

- Um Processo Sociológico gera fenômenos resultantes das atividades sociais dos seres humanos. Somente os efeitos de um processo sociológico são descritos no modelo, considerando que não é necessário representar as atividades dos agentes na origem desse fenômeno, que é como ele é gerado.

- Uma Atividade é um processo executado por um agente que pretende atingir alguns objetivos. Um objetivo está ligado à atividade visando sua realização.

Cada agente está associado a um comportamento que descreve como "orquestrar" suas várias atividades, solucionar conflitos que possam aparecer entre elas e decidir executar (ou não), uma ação em vez de outra. Está condição alinha-se à metodologia análitica que propomos nesta dissertação, o modelo Mannis, descrito amplamente no capítulo VI.

A descrição de um processo (ecológico ou social) é dividida em ações que podem ser decompostas em sub-ações. Esta dinâmica de processo reproduz a programação de ações executáveis como em um sistema de equações, um autômato, um

12 No original link. Conceito referente à vincular ações, afetos, sensações entre outras condições

13 No original sócio-econômico. Consideremos que embora a estrutura econômica influencie as condições dos sistemas complexos, nosso enfoque limita-se ao processo ecológico, desta forma, evitaremos discutir essa estrutura neste trabalho. 
algoritmo ou um conjunto de regras. Um processo dinâmico utiliza entidades, (recursos ou agentes) cujos estados condicionam seu desenvolvimento. Os processos interagem mediante as entidades. Ou seja, é através de mudanças nos estados das entidades impactadas que um processo afeta o curso dos processos que dependem dessas entidades.

Sugerimos a adição de mais uma entidade ao conceito de processo dinâmico, a entidade Gelassenheit. Este tipo de entidade interfere de modo estocástico em sistemas socioecológicos alterando de forma estrutural todo o processo. Esse tipo de entidade não pode ser previsto e sua condição não está associada à qualquer intencionalidade. A entidade Gelassenheit será explicada de forma mais objetiva no capítulo VI.

\subsection{Interações entre o Sistema e Meio Ambiente}

Os sistemas socioecológicos são sistemas abertos que interagem com o seu ambiente. As entidades e os processos são conteúdos que estão fora do sistema e exercem influência sobre ele. Em uma modelagem de sistemas socioecológicos se considera essas interações através da configuração de recursos na interface do sistema, o que chamamos de "processo externo" (SIBERTIN-BLANC et al., 2011). Um "processo externo" é um procedimento cuja execução não é afetada pelo estado do sistema modelado e que altera as condições de algumas entidades.

Uma entidade de interface pode ser impactada por processos externos e internos. Classicamente, a dinâmica de um processo externo não é representada, mas sim seus impactos. Estes impactos são comumente enquadrados como uma série (espacial) temporal, representados pelas principais ações visualizadas no sistema. Denominamos agente externo aquele que executa apenas as atividades externas.

\subsection{Comportamento e Dinâmica dos Diagramas}

Um diagrama dinâmico descreve a dinâmica de um processo, desta forma, é necessário que exista um diagrama dinâmico para cada processo interiorizado. Ou seja, descrever as ações do processo e quais devem ser realizadas em cada etapa do tempo da simulação. Como há muitas maneiras de formalizar uma dinâmica de um processo, nenhuma padronização é proposta (CHENET PIN-SHAN, 1976). Questionamentos podem ser levantados sobre a multiplicidade das instâncias de entidades no modelo performance/experimento impactados pela execução de um processo em cada etapa temporal. Consideramos que cada processo ocorre de forma singular e uma única vez, aplicando todas as instâncias (concretas) das entidades impactadas (CHENET PIN-SHAN, 1976).

Nesta perspectiva, os processos proporcionam interação através das entidades 
da estrutura do modelo. Para garantir uma ação dentro da mesma estrutura, não devem ocorrer ambigüidades sobre as identidades das entidades envolvidas e suas execuções. Por exemplo, o diagrama de comportamento de um agente descreve como este, que possui várias atividades para executar, seleciona dentre as ações, atividades habilitadas pelo estado do sistema atual as quais serão efetivamente executadas. As diversas atividades de um agente devem ser descritas usando o mesmo formalismo, que também pode ser usado para a descrição do diagrama de comportamento.

\subsection{Cenários e Indicadores}

O conceito de cenários, pretende expor o efeito sobre o comportamento do sistema diante de várias hipóteses (SIBERTIN-BLANC et al., 2011). Eles são expressos como variações do modelo performance/experimento. Podem englobar mudanças em:

1) a dinâmica de processos internos, notadamente seus parâmetros;

2) o impacto de processos externos sobre entidades de interface;

3) os estados iniciais de entidades e vínculos ao modelo performance/experimento;

A avaliação integrada dos cenários normalmente é realizada através da análise do valor dos indicativos derivados das variações finais do processo da performance/experimento, ou do estado final das entidades.

\subsection{Documentação do Modelo e Cenários}

O modelo do sistema descreve uma estrutura inicial e qual estado a ser experimentado (mais ou menos ordenado, mais ou menos adaptável), considerando as instâncias das entidades e seu estado, juntamente com seus vínculos. Uma documentação abrangente do modelo deve descrever (SIBERTIN-BLANC et al., 2011):

1) As instâncias concretas das entidades do modelo: incluindo os valores de suas propriedades e seus vínculos, além das fontes dos dados utilizados para definir essas instâncias; Se as instâncias de algumas entidades são muito numerosas, elas não são descritas individualmente, e sim por uma lei probabilística que distribui os valores de suas propriedades;

2) As fontes dos dados que são/serão utilizados para alimentar os processos externos e como eles são processados, (ajustar a estrutura das entidades de interface);

3) Uma especificação implementável da dinâmica e das ações de cada processo;

4) Os algoritmos que permitem expandir os indicadores: 


\subsection{Modelo de Simulação - Modelo de Performance/Experimento}

O modelo de performance/experimento é uma implementação de um modelo simulado (ou uma condição de cenários). Classicamente, o modelo de simulação assemelha se à uma "black box ${ }^{14}$ " para a maioria dos participantes no processo de modelagem (RESNICK et al., 2000). Eles não sabem até que ponto o modelo de simulação é uma implementação fiel do experimento.

Usando o modelo baseado em entidades-processos, a estrutura do modelo de simulação pode espelhar a do modelo performance/experimento e assim evitar a ocorrência de distorções entre os dois modelos. As inter-relações são portanto implementadas como atributos oriundos das entidades, em acordo com as relações que podem ser deduzidas das ações processuais.

Devido à estrutura de comportamento do modelo, (como um conjunto de processos que interagem de forma assíncrona por meio de entidades), o princípio que faz a simulação progredir é bastante simples. Assumindo que as escalas de tempo de todos os processos estão alinhadas, a cada momento existem as seguintes realizações:

1) Cada processo ecológico e sociológico interno ativa a dinâmica para selecionar as ações;

2) Cada agente, ativa seu comportamento para selecionar as ações de cada uma de suas atividades habilitadas. Seu comportamento, seleciona a(s) ação(ões) a ser(em) executada(s);

3) A atualização do estado das entidades de interface (como resultado do efeito de processos externos);

4) As performances de ações selecionadas por cada processo biofísico interno, por cada processo sociológico e, em seguida, pelo comportamento de cada agente. Em caso de conflito entre algumas ações, este deve ser resolvido de forma aleatória ou seguindo regras bem específicas.

Portanto, uma simulação corresponde a uma performance/experiência aplicando o princípio do modelo e do cenário. Cada experimento permite avaliar indicadores. A comparação dos valores dos indicadores de um dado cenário com os de uma referência, seja a situação atual ou um cenário de referência, permite a avaliação integrada dos cenários (SIBERTIN-BLANC et al., 2011).

14 Em ciência, informática e engenharia, uma caixa preta é um dispositivo, sistema ou objeto que pode ser visto em termos de entradas e saídas (ou características de transferência), sem qualquer conhecimento de seus trabalhos internos. Exemplos de black box: um transistor, um algoritmo ou o cérebro humano. 
4.9 Modelo de Simulação 1- Proposta de Modelagem de Síntese Ecológica (PMSE)

Objetivamos uma expansão da proposta de modelagem de síntese ecológica partindo dos pressupostos de Keller (1999), onde se utilizam fontes sonoras reconhecíveis, considerando uma localização espacial consistente ao material sonoro e aplicando transformações ecologicamente viáveis nas fontes. Nesta perspectiva as transformações proporcionam estratégias para a composição. Portanto, uma unidade ecologicamente relevante é o menor elemento da composição. A macro-organização do material por sua vez é o resultado das interações em um nível meso e micro.

As interações oferecem parâmetros baseados em diretrizes que fornecem material consistente com a produção de som realísticos (não sintetizados). Desta forma, a organização temporal dos eventos é definida por padrões de tempo que ocorrem, ou pelo menos podem ocorrer, em situações do mundo real (KELLER, 1999).

Segundo Keller (1999):

A abordagem ecológica não pode ser estudada isolando suas partes. Todos os modelos devem ser restritos à eventos ecologicamente viáveis. A validade ecológica é definida pela observação de interações complexas que realmente ocorrem no ambiente. A ação do indivíduo no ambiente e a influência do ambiente sobre o indivíduo determinam o processo de formação do padrão. Este processo pode ser aproximadamente modelado por ferramentas algorítmicas. As características espectrais e temporais dos eventos sonoros precisam ser contabilizadas no processo de modelagem (KELLER, 1999).

Seguindo a premissa, Keller (1999) aponta que os métodos ecológicos se posicionam em dois pilares onde as técnicas básicas ampliam as possibilidades criativas introduzindo sons sintetizados dentro do contexto de gravações de cenários sonoros: 1) Modelos Físicos Genéricos, 2) Controle Meso-padrão de Conjuntos em Amostras Granulares.

Keller (1999) não aborda conteúdos em seu trabalho que possam ser consideradas contingências nestes ambientes, que sob uma ótica musical determinamos como improvisação. Consideramos portanto, que ao introduzir uma modelagem de síntese ecológica diante de parâmetros de sistemas socioecológicos, sugerimos aceitar que a auto-organização destes ambientes podem ou não conter regras determinísticas e/ou causalidades.

Ao adicionarmos processamento de áudio ampliando as possibilidades sonoras de uma ecologia, introduzimos recursos materiais e cognitivos que estão previstos nos modelos de sistemas socioecológicos. Desta forma, nossa PMSE permite introduzir recursos materiais que podem conter planos de diretrizes ou contingenciais. Por exemplo, durante uma performance podemos adicionar um tipo de processamento de áudio 
periodicamente estipulado, (plano de diretrizes) ou através da tomada de decisões abordarmos os recursos em um momento propício, (plano de contingências).

Ambos, plano de diretrizes ou contingências, encontram relevância nos recursos cognitivos limitados à intencionalidade do(s) agente(s) sobre o material. A diferença encontra-se na ação temporal. Composicionalmente temos escolhas em tempo diferido enquanto em um sistema improvisatório as ações serão tomadas em tempo real. $A$ significação da relevância em ambos os planos não condiz com uma ação unânime. Este processo é caracterizado por uma forma de análise qualitativa individual a cada agente imerso nos sistemas socioecológicos. Este processo é melhor detalhado no modelo Mannis no capítulo V.

Na PMSE, a modelagem irá considerar os pré-requisitos dos sistemas socioecológicos como: processo ecológico e processo sociológico. O processo ecológico pode ser permeado em três níveis:

1) o ambiente ecológico real: onde todos agentes se localizam e tendem a produzir suas atividades.

2) o ambiente ecológico sintetizado: a inclusão de recursos materiais sintéticos, (como processamentos de áudio), ao ambiente. Estes materiais podem ser incluídos de forma intencional ou não.

3) O metasoundscape (ALIEL; FORNARI, 2013): amalgamento entre os dois ambientes de forma remota.

O processo sociológico por sua vez, gera fenômenos resultantes das atividades sociais dos seres humanos. Somente os efeitos de um processo sociológico são descritos no modelo, considerando que não é necessário representar as atividades dos agentes na origem desse fenômeno, que é como ele é gerado. Entretanto podemos considerar fatores cognitivos como:

1) Imitação: capacidade de valer de condições de mimese baseada em percepção, análise e síntese, (MANNIS, 2014);

2) Atividade exploratória (KELLER et al., 2014): capacidade em descobrir os recursos materiais e procurar desenvolver interações com ambiente, outros agentes e entidades gelassenheit ${ }^{15}$

3) Atividade epistêmica: construção do saber de modo empírico, com objetivação de interação via recurso material criativo sem obrigatoriedade de resultados diretos [KELLER et al. 2010];

15 Melhor abordado no capítulo IV 
Deve-se adicionar ao PMSE a condição de inclusão de agentes externos prevista nos sistemas socioecológicos. Em nosso caso que lidamos com ambientes comprovisados, os agentes externos serão orientados pelas entidades Gelassenheit. Esta entidade permite em tese abordar todo e qualquer evento natural ou sintetizado que não pode ser previsto, mas que afetará o sistema como um todo.

Sobre os agentes, a PMSE incluirá três tipos de indivíduos:

1) Agentes performáticos (músicos)

2) Agentes Incisos (não músicos)

3) Entidade Gelassenheit (agente imprevisível). Os três perfis de agentes podem ou não interagir através de atividades. Os agentes serão melhor comentados no capítulo V.

Consequentemente, à partir dos pré-requisitos dos sistemas socioecológicos, elaboramos nosso PMSE que tem por base os apontamentos de Keller (1999) e expande as condições sugeridas voltadas para composição musical elencando a possibilidade de inclusão da improvisação em ecologias sonoras. O PMSE deverá ser utilizado em estudos de caso abordados nesta dissertação. Através dos estudos de casos devemos adicionar ou remover conteúdo do PMSE, a fim de produzir uma modelagem mais significativa para propostas de trabalhos artísticos em ecologia sonora.

\subsection{Modelo de Simulação 2 - Proposta de Modelagem em Looping - PL}

Em uma segunda via de propostas para desenvolver modelos para trabalhos em sistema socioecológico que utilizem conceitos comprovisatórios, consideramos a proposta de modelagem em looping (PL). Um looping em contextos sonoros são sessões de repetições. Também conhecido como ostinatos em um conceito mais tradicional em música. Utilizaremos a denominação looping em um contexto onde uma estrutura se repete invariavelmente tornando-se parte de um contexto maior, o ambiente. Podemos sugerir que diversas fontes sonoras ecológicas ocorrem em uma metáfora aos loopings. Por exemplo, o som da chuva em um viés macro tornase perceptivelmente semelhante à um looping (se desconsiderarmos as mudanças de intensidade da chuva), entretanto, cada gota possui de fato uma singularidade sonora. Em outras palavras, embora o looping esteja associado a repetição idêntica, neste trabalho trataremos o looping sob uma circunstância de repetição com micro variações, tornando o objeto macro quase idêntico, porém singular. Em nossa proposta de modelagem em looping, consideramos que o material acústico e eletrônico no ambiente irão obedecer os mesmo parâmetros. Esta abordagem pode ser considerada uma expansão aos trabalhos de Di Scipio sobre causalidade circular (2003)

O compositor Agostino Di Scipio vem utilizando em sua carreira artística a 
construção de obras sonoras que permeiam a interação entre homem, máquina e ambiente. Um dos seus principais trabalhos na área foi Audible Eco-Systemic Interface (AESI). Neste projeto, Di Scipio cria sínteses sonoras que entram em contato com o ambiente e se retroalimentam através da captação de microfones espalhados pelo ambiente. Todo o pensamento de Di Scipio gira em torno das interações sonoras e dos loopings criados devidos às retro-alimentações.

Em seu artigo intitulado 'Sound is the interface': from interactive to ecosystemic signal processing (DI SCIPIO, 2003) faz apontamentos sobre o AESI, e como conceitua os trabalhos através de retroalimentação sonora. Parte dos apontamentos do autor são conduzidos por questões empíricas e pouco formalizadas. Mesmo quando há relacionamentos com questões sobre modelagens de sistemas ou algum tipo de formalização dos conceitos, estes não são claro, nem específicos. Embora este fator seja uma crítica ao trabalho, consideramos que o trabalho de Di Scipio produz material significativo como ponto de partida para desenvolver uma modelagem ecológica capaz de ser performada, experimentada e replicada em análises. Um dos principais pontos tratados por Di Scipio é sobre o controle dos materiais dentro do sistema.

\begin{abstract}
O objetivo principal dos dados de controle é determinar as mudanças de estado interno do sistema. Isto é feito indiretamente, atualizando os parâmetros com qualquer técnica de processamento de sinal digital ou alterando rotinas de programas operando em um nível mais abstrato, simbólico. As mudanças do estado interno são mudanças ouvidas na saída músical. Ao operar os dispositivos de controle, o agente "toca" o sistema como se fosse um novo tipo de instrumento de música (DI SCIPIO, 2003).
\end{abstract}

O autor portanto determina que um sistema complexo deve possuir um certo nível de controle (como de um instrumento musical) para alcançar uma expressividade artística. $\mathrm{O}$ fato pode ser relevante, e traz um contraponto à nossa pesquisa. Em nossa perspectiva, podemos considerar que Di Scipio se refere a controle dentro de um plano de diretrizes. Mas o que aparentemente o autor indica são condições em tempo real, tais como "atualização de parâmetros" ou "alteração de rotinas". Estas condições parecem mais relacionadas a planos contingenciais do que de fato com diretrizes. O texto de Di Scipio chega a citar condições de improvisação em sistema como o AESI, entretanto, não há aprofundamento nem estruturação de quais condições serão consideradas como improvisações.

Outro fator relevante à discussão são os apontamentos de Di Scipio sobre as influências externas ao sistema proposto. Neste direcionamento, o autor afirma que "o papel do agente-performer parece ambivalente, afinal, é o único significante das condições externas do sistema e, ao mesmo tempo, representa um componente interno do meta-sistema, incluindo homem, máquina e ambiente" (DI SCIPIO, 2003). 
O autor busca traçar uma condição de "função" para o performer, sendo este o indivíduo fundamental para construção do sistema. Consideramos os apontamentos de Di Scipio parcialmente alinhados com nossa compreensão de ecologia sonora. Ou seja, ao considerar uma condição de ecologia sonora, sob a perspectiva das instâncias perceptivas das entidades em sistemas complexos, não podemos desconsiderar todas as contribuições criativas que podem ser alcançadas por todos os fatores existentes no sistema (internos ou externos). Nesse viés, o agente-performer pode ser considerado a principal via para a ocorrência de eventos significativos ou atividades Sibertin-Blanc et al (2011), mas não o único.

Di Scipio, diante dos conceitos de interação, controle e agente-performers propõe um modelo que considera relevante para construção de obras artísticas. Podemos observar um diagrama retirado do trabalho do autor:

Figura 3 - Modelo de sistema de retroalimentação em looping proposto por Di Scipio

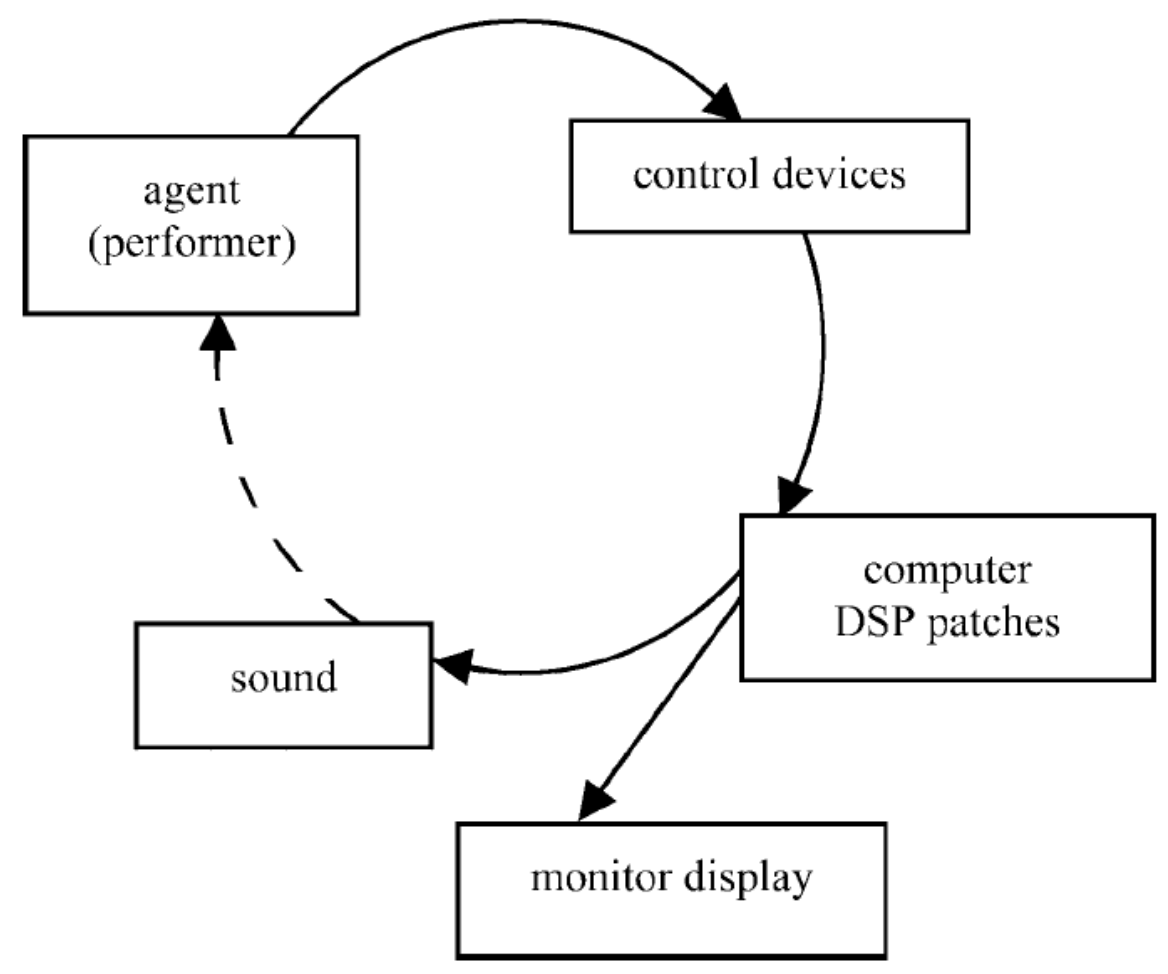

Em suas palavras:

Este design assume implicitamente um elemento recursivo, ou seja, um loop entre o som de saída e o agente-performer: o agente determina as mudanças de estado interno do computador, e este último, ouvido pelo agente, pode afetar sua próxima ação que por sua vez pode afetar o estado interno do computador de alguma forma. Este elemento 
recursivo é uma fonte de desenvolvimento criativo, mas permanece puramente opcional (seta tracejada na figura), pois o fluxo básico de comunicação é linear. O performer é primeiro o agente iniciador da reação do computador, e somente em segundo lugar, opcionalmente, pode se tornar o próprio locus de feedback, injetando algum ruído no circuito do sistema global.(DI SCIPIO, 2003).

Partindo da análise do comportamento do sistema proposto por Di Scipio, encontramos uma condição de plano de diretriz bem definida e com certa abertura para planos contingenciais. Embora em sua fala, a condição de contingência não seja levantada, podemos sugerir que palavras como "opcional" façam essa conexão diretrizes/contingências. Entendemos que este sistema se encaixe nos padrões metodológicos de uma comprovisação. A aparente intencionalidade do performance na ótica do autor trata-se de uma condição de total contingência do momento. Ou seja, parte de um processo puramente contingencial capaz de modificar o sistema como um todo.

Seguindo uma análise mais formal, Di Scipio apresenta seu sistema como um sistema não linear. Para Sanfilippo e Valle, (2012) um sistema não linear é o resultado de variáveis nas duas estruturas input e output. Um sistema de feedback é um típico sistema não linear resultante de um processo de causalidade circular [SANFILIPPO; VALLE, 2012]. As causas (interações ${ }^{16}$ ) se realimentam através de efeitos, e o resultado de suas combinações podem quebrar a proporção linear de insumo-produto. Do ponto de vista musical, a não linearidade emerge em sistemas baseados em retroalimentação onde as mutações de variáveis internas podem resultar em comportamentos muito diferentes na saída final [SANFILIPPO; VALLE, 2012]. Este comportamento de variação de saída em contraposição às de entrada produziram o que Di Scipio denomina causalidade circular.

Para Solomos (2013) graças a esta causalidade circular, Di Scipio redefiniu a noção usual em live eletronics, ou seja, o processo de "interação“ (DI SCIPIO, 2003). Nessa concepção, a interação opera como um fluxo de informação: uma fonte de som que é transformada. Assim, na realidade, o sistema não é muito interativo. Para Di Scipio, a própria composição poderia ser a ação de compor interações. Nas palavras de Di Scipio (2003):

O principal objetivo seria a criação de um sistema dinâmico que exibe um comportamento adaptativo às condições externas próxima, sendo capaz de interferir nas mesmas condições externas. [...] Uma espécie de auto-organização é, portanto, alcançada [... ]. Aqui, "interação" é um elemento estrutural como um "sistema" a emergir [... . Sistemas de interações só seriam indiretamente implementados em subprodutos de interdependências cuidadosamente arquitetadas entre os componentes do sistema [...]. Este é um movimento substancial de composição em

16 Adição do autor 
música interativa intuído compor (comprovisar ${ }^{17}$ ) interações musicais e, talvez, mais precisamente, deve ser descrito como uma mudança no modo de criar sons através de meios interativos, direcionando para uma criação que busque interações com traços sonoros.[DI SCIPIO, 2003: 271].

Di Scipio portanto, limita-se a propor uma criação de ambiente adaptável através de interações, mas não formaliza efetivamente como o sistema funciona. Aparentemente, os recursos cognitivos determinam o decorrer das interações automaticamente, e o sistema emerge e se auto regula. Esta concepção pode ser aceita e propiciar fragmentos expressivos de arte sonora, entretanto, torna-se de difícil avaliação e medição. Acreditamos que o sistema possa ser mais especificado ao ser expandido possibilitando maior medição e também inclusão de outras entidades que talvez não tenham sido relevantes para Di Scipio.

\subsection{Formalizando a Modelagem em Looping}

Buscando uma expansão do trabalho de Di Scipio iremos considerar o sistema socioecológico para abordar as interações sugeridas pelo autor e acrescentar condições, recursos e agentes que possam ser relevantes nesse tipo de trabalho artístico.

Diferentemente de Di Scipio, não abordaremos o sistema apenas sob a ótica das interações, mais nos focaremos nos comportamentos que acionam ações. Segundo a literatura em sistemas socioecológicos utilizados neste trabalho, as interações são um dos comportamentos visíveis em agentes, mas não os únicos. Considerando que todo o sistema socioecológico está relacionado à três condições principais: processos ecológicos, processos sociológicos e atividade (Sibertin et al, 2011), estes podem vir de ações internas ou externas, e estão primariamente ligadas às percepções e ações dos agentes. De maneira geral, os processos ecológicos e sociológicos estão ligados à capacidade perceptiva dos agentes, enquanto que as atividades estão relacionadas aos objetivos e ações. Os objetivos/ações se relacionam com as três entidades principais que são: os recursos cognitivos, o agente e os recursos materiais (como descritos com mais clareza no ínicio do capítulo). Estas três entidades do sistema propiciam a atividade no sistema que pode ser mais ou menos mutável devido às circunstâncias.

Ao objetivar um sistema em looping que permita uma associação com padrões ecológicos, consideramos que nosso sistema não segue um padrão linear como proposto por Di Scipio. Nesta fundamentação, o processo de produção sonora, seja acústica ou eletrônica, parte de múltiplas condições (como visto no diagrama de SIBERTIN et al, 2011. (vide figura 03). Mesmo que o ambiente proporcione um material retro-alimentado similar, as percepções dos agentes podem mudar devido ao 
processo temporal. Desta forma, um recurso material em looping, ou seja, o objeto sendo repetido de forma exata e invariável torna-se uma instância de entidade que pode vir a alterar os recursos cognitivos dos agentes. Toda e qualquer mutação, seja perceptiva ou objetiva no sistema tende a transformá-la. O próprio sistema se torna não-linear, afinal, os resultados finais não são idênticos aos iniciais. Em conjunturas como estas, diferentes repetições podem vir de processos externos ao sistema, como paisagens sonoras captadas em tempo real, ou de processos internos ao sistema como samples sendo disparados. Ambas as condições permitem variações que podem ser mais ou menos drásticas, ficando a cabo das contingências (atividades), dos recursos materiais e cognitivos determinarem o quanto contrastantes essas serão. Seguindo esta lógica, os loopings seriam pequenas instâncias de entidades que se adaptam de forma mais ou menos complexa devido aos processos socioecológicos. A partir de uma formalização regulada pela percepção e ação das entidades, encontramos um quadro associativo à eventos recorrentes em sistemas ecológicos, tornando o looping fundamental à esta pesquisa. 


\section{Metodologia Analítica - Aspectos Teóricos para Análise dos Estudos de Caso}

Nesta seção discutimos dois modelos teóricos recentes que têm aplicabilidade no contexto das práticas criativas ecológicas. O primeiro modelo baseia-se na formulação da técnica de análise-síntese que teve ampla divulgação na implementação do processamento de áudio a partir do final dos anos 1960. O segundo quadro teórico foca a questão da criatividade distribuída dando ênfase para os aspectos coletivos da prática musical. Após a apresentação das características principais de cada enfoque, abordamos as contribuições específicas e as limitações das duas propostas dentro do campo das práticas criativas musicais. De forma geral, iremos propor dois modelos para orientar nossa análise criativa/performática dos estudos de caso, estruturada pela base teórica desenvolvida neste trabalho. A priori, o modelo MM (MANNIS, 2014) terá um cunho qualitativo, orientando a análise dos recursos cognitivos. O modelo MDF (FERRAZ; KELLER, 2014) se voltará a uma análise quantitativa dos recursos materiais, buscando estabelecer parâmetros mensuráveis dos comportamentos envolvendo os múltiplos agentes.

\subsection{Modelo MM (Modelo Mannis, 2014)}

O modelo desenvolvido por Mannis (2014) - MM - aplica a noção de análisesíntese sonora (LUCE, 1963) para o domínio da prática criativa. Este modelo de três estágios é estruturado como uma sequência cíclica direcionada. Segundo Mannis, o ciclo criativo inicia-se com a percepção. As operações de associação, de comparação e de classificação são aplicadas após a extração da informação sonora. No segundo estágio - análise - modelos musicais, estruturas e taxonomias previamente estabelecidas são empregados para fornecer a base para um processo de construção de hipóteses. Três grandes estratégias estão disponíveis: a regressiva (ou subtrativa), a expansiva (ou aditiva) e o desvio (detouring) (processo exemplificado em FERRAZ, 1998 e em COSTA, 2009). Alternativamente, Mannis menciona as abordagens tradicionais para a resolução de problemas, incluindo a dedução, a indução e a abdução. Os aspectos situados-corporizados da proposta estão explicitamente voltados aos procedimentos de mímesis. Esses processos acontecem durante a fase de síntese. Através da assimilação (incorporação de conhecimento novo) estabelece-se um contínuo entre a representação realista do som e a construção de novos conceitos. A assimilação alimenta o estágio de percepção, fornecendo a base para a interação.

Mímesis é um termo crítico e filosófico que abarca uma variedade de significados. A priori, condiz com a imitação, representação, mímica, imitatio, receptividade, ato de 
se assemelhar, ato de expressão e apresentação do eu. No contexto deste trabalho, usamos uma variação da proposta de Mannis (2014) sobre mímesis, onde este é entendido como o conjunto de reações (gestual, sonora e etc.) às quais os agentes recorrem nos processos de interação. Por exemplo, em uma performance/experiência em que um agente produz uma técnica, uma descoberta de som ou uma condição relevante para os outros agentes, esta condição torna-se um gatilho para ações criativas que podem ser imitadas por outros agentes. A mímesis torna-se assim uma ferramenta quantitativa para analisar práticas grupais criativas, afinal, conseguimos apontar quando e como as ações imitativas ocorreram nos eventos.

Figura 4 - Diagrama do Modelo Mannis (2014): Percepção-Análise-Síntese.

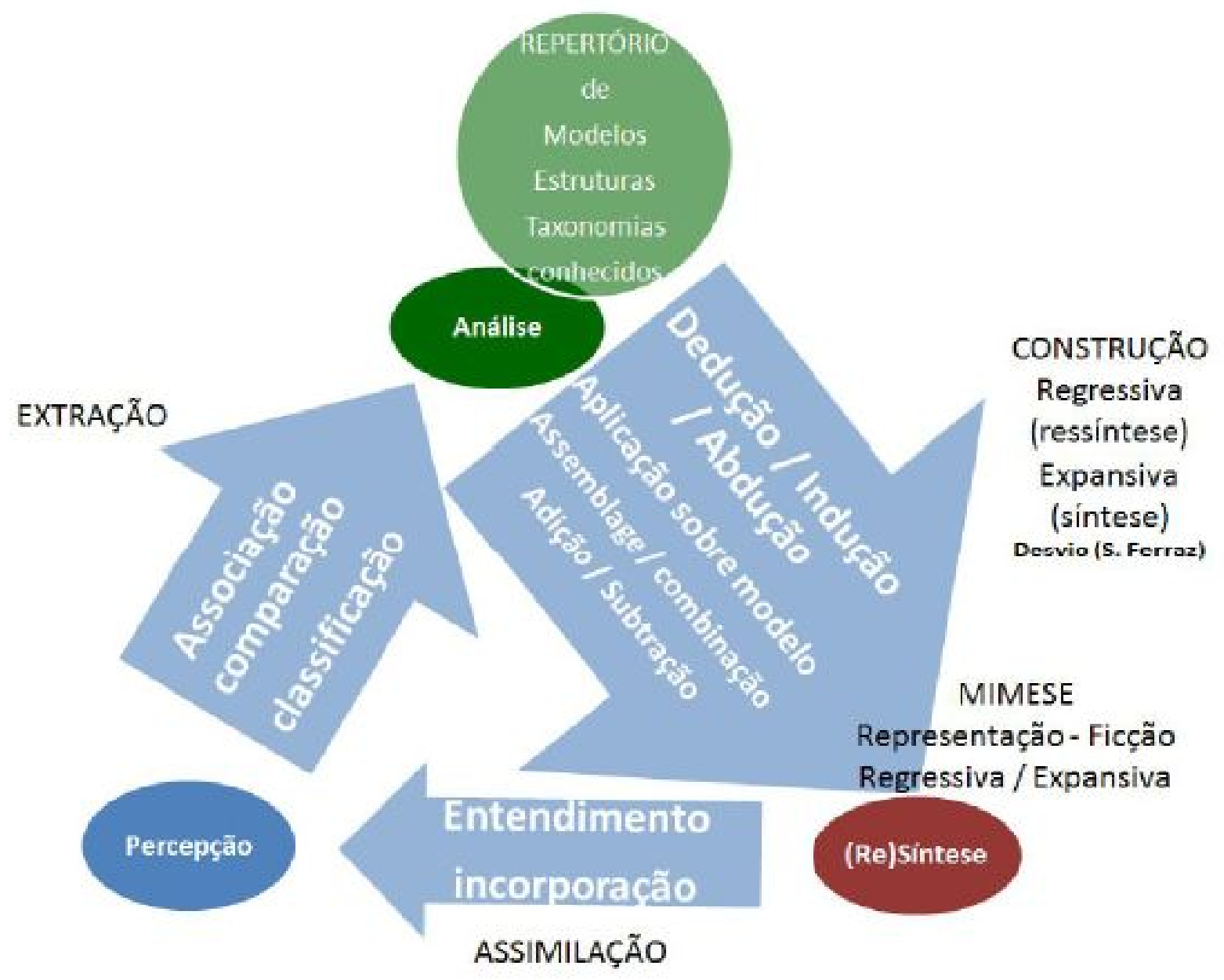

O modelo proposto por Mannis (2014) é muito similar ao modelo interativo de Younker e Burnard (2004) - YBM. O estágio de percepção fornece uma versão expandida do estágio find do YBM. Ambos modelos referem-se à atividade de foraging que é geralmente descrita como uma fase gerativa pré-compositional. A etapa de análise tem uma estreita semelhança com o estágio fixo do YBM, envolvendo a seleção e classificação de recursos para proporcionar um ambiente viável para a tomada de 
decisões. Finalmente, a fase de síntese envolve os processos subtrativos implícitos no estágio focus do YBM. No entanto, o modelo MM difere em dois aspectos da estrutura do modelo YBM. Primeiramente, o fluxo é direcional, isto é, as fases seguem uma sequência fixa: percepção-análise-síntese. A estrutura do modelo YBM é não-direcional, qualquer fase pode seguir ou preceder qualquer outra fase. Além disso, o modelo YBM inclui o estágio de incubação de Wallas (1926), neste caso denominado time away. O modelo MM não representa de forma explícita a falta de ação ou de investimento na atividade-foco.

Tanto as interações sociais quanto a interação ecológica parecem moldar os canais de interação nas práticas criativas (KELLER et al., 2010). A mimese pode ser aplicada através de duas estratégias de extração de informação: nas interações através de affordances sociais e nas interações com recursos materiais (também denominadas affordances naturais). MM incorpora as três operações propostas por (KELLER, 2012) e (FERRAZ; KELLER, 2012): expansão (expand), restrição (constrain) e translação (shift). A operação de translação (shift) (que em MM é denominada desvio - detouring) tem como objetivo os mecanismos que não encaixam nas abordagens clássicas de resolução de problemas (NEWELL et al., 1958). Esta operação fornece recursos materiais, comportamentais ou cognitivos que não estão disponíveis previamente ao início da atividade criativa. Uma característica fundamental das abordagens baseadas na cognição situada-corporizada é a estreita interação entre percepção e ação (GIBSON, 1979). Segundo essa abordagem, o elo mais forte do modelo MM com os paradigmas da cognição ecológica é a emergência de recursos materiais e cognitivos durante a atividade exploratória, ao invés da aplicação de estratégias analíticas abstratas ou da formulação explícita de problemas como ato prévio à exploração dos recursos materiais. Portanto, as operações de expansão, restrição e translação - aplicadas nas perspectivas ecológicas - são compatíveis com a geração de recursos durante a atividade mas não encaixam no modelo tradicional de solução de problemas já que este último demanda a separação a priori entre os recursos disponíveis e os processos de planejamento e de tomada de decisões estéticas.

Algumas das limitações dos modelos de criatividade discutidos em (KELLER et al., 2011) também se aplicam à proposta de percepção-análise-síntese. Apesar do impulso dado à incorporação dos processos de mimese no modelo MM, Mannis parece adotar uma abordagem restrita ao aplicar os conceitos ecológicos. Os avanços recentes em cognição ecológica apontam para a importância da interação social como um mecanismo de estabilização do conhecimento compartilhado (HUTCHINS, 2010). A dimensão social tem sido abordada nas práticas criativas cognitivo-ecológicas desde o ano 2000 (KELLER; CAPASSO, 2000; KELLER et al., 2011). Em particular, o conceito de público ou audiência (audience) (GLAVEANU, 2013) sugere que os modelos de criatividade precisam levar em conta as interações com participantes não especialistas. 
Essa dimensão não aparece de forma explícita no modelo MM.

Outro fator que parece estar ausente no modelo MM é o lugar (place) (RHODES, 1961). Muito aquém da utilização de recursos ecológicos para moldar as decisões estéticas (KELLER, 2000; TRUAX, 2002), a interpretação proposta no modelo MM parece estar restrita à mimese dos gestos corporais. Sem dúvida, esse é um aspecto importante dos fenômenos criativos, mas o leque de informações ambientais que afetam a atividade criativa não abrange só os comportamentos humanos. Indica-se que os recursos materiais - os objetos presentes no espaço criativo - e os recursos cognitivos - as percepções dos indivíduos presentes no espaço criativo - podem moldar as ações dos agentes, direcionando os processos de escolhas estéticas (KELLER et al., 2013). Como observamos nos estudos de caso analisados com maior profundidade no capítulo $\mathrm{V}$ desta dissertação, as práticas ecológicas mostram que os canais materiais de interação (ou affordances materiais) devem ser considerados em pé de igualdade com as affordances sociais (cf. BASANTA, 2010; BURTNER, 2005; NANCE, 2007).

Resumindo, o modelo MM está alinhado com as propostas teóricas que fundamentam as práticas criativas ecológicas, com ênfase nos recursos cognitivos, oferecendo suporte para a adoção de processos de retroalimentação na criação musical. As três operações que envolvem expansão, redução e translação de recursos encontramse no cerne das propostas ecológicas já existentes. A ênfase dada aos processos de mímese é consistente com as propostas fundamentadas no compartilhamento social dos recursos. No entanto, o modelo MM apresenta algumas limitações quanto ao tratamento dos fatores de apoio à criatividade que vêm sendo discutidos desde as perspectivas vinculadas à criatividade geral. Primeiro, o ciclo de percepção-análise-síntese não contempla a atividade desvinculada de objetivos explícitos. A incubação (WALLAS, 1926), envolvendo o tempo não dedicado à atividade específica, pode ter impacto nos resultados e nos processos criativos. Segundo, a separação dos processos criativos em estágios sucessivos - indicada através de setas unidirecionais - não é compatível com os modelos não hierárquicos e auto-organizados. É possível que a organização formal demande processos de desmembramento de recursos materiais ou de combinação dos recursos existentes em unidades de complexidade crescente. No entanto, os fenômenos de auto-organização não indicam que seja necessária uma fase analítica prévia à produção de resultados criativos complexos. Terceiro, a falta de representação explícita dos agentes não especialistas - a audiência - exclui a possibilidade de participação comunitária nos processos de tomada de decisões. Por último, a exclusão do fator local - identificado nos modelos fundamentados em cognição situada-corporizada a partir dos recursos materiais - indica uma limitação importante na aplicabilidade do MM. Ao não especificar a função dos recursos materiais, o modelo $M M$ não fornece variáveis que permitam fazer comparações entre atividades criativas realizadas em contextos diversos. Algumas dessas limitações estão sendo focadas no contexto do 
desenvolvimento do Modelo Dentro-Fora (MDF). Apresentamos a seguir os elementos básicos desse modelo e discutimos as vantagens e limitações.

\subsection{Modelo Dentro-Fora}

As práticas ecológicas enfatizam o caráter procedimental da atividade criativa, fomentando o suporte para as fases iniciais do ciclo criativo através do embasamento nos resultados empíricos da pesquisa em cognição situada-corporizada, oferecendo destaque para o perfil distribuído dos fenômenos criativos, abrangendo tanto o impacto dos recursos materiais quanto a sustentação nos fatores sociais. Villena (2014) menciona como uma das contribuições da pesquisa em ecocomposição, a implementação de teorias e métodos voltados para as práticas criativas grupais. Ele cita o Modelo Dentro-Fora (MDF) (FERRAZ; KELLER, 2012) como uma das propostas que podem contribuir para superar o foco nos aspectos individuais das práticas criativas musicais. O MDF trata dos fatores humanos que determinam os mecanismos de criação coletiva como resultado de duas forças: para-dentro e para-fora. Essas duas forças atuam a nível grupal sendo moduladas e influenciando os fatores sociais e os fatores materiais. Em particular, as interações entre agentes e objetos determinam um campo epistêmico específico para cada componente do grupo. Esses campos epistêmicos interagem durante o processo de criação coletiva impulsionando os fenômenos de aglutinação e desagregação. Os resultados são diversos tipos de comportamentos coletivos que aumentam ou reduzem o potencial criativo do grupo.

Por outro lado, o MDF também dá destaque aos aspectos materiais da prática criativa. Ao definir a criação musical como atividade (BARREIRO; KELLER, 2010), o suporte material pode ser incorporado como recurso que é utilizado durante o processo criativo ou como produto desse processo. Entre os recursos materiais, incluímos tanto os objetos disponíveis no ambiente da atividade criativa quanto os elementos acessíveis através de infraestrutura tecnológica de suporte (creative support tools - SHNEIDERMAN et al., 2006). Isso significa que - no mínimo - estamos falando de dois tipos de recursos: os materiais existentes no local da atividade (o que na literatura sobre criatividade normalmente se define como o fator 'lugar' (place) e os materiais que dependem do suporte tecnológico para sua inclusão na atividade. Esses recursos podem ser renováveis, ou seja, eles podem ser reutilizados múltiplas vezes sem necessidade de acessar o ambiente externo à atividade; e também podem ser nãorivais, isto é, eles podem ser compartilhados entre os agentes que estão realizando a atividade sem perder o seu valor criativo. No entanto, geralmente os recursos materiais utilizados em atividades criativas são rivais e não-renováveis: eles perdem valor criativo quando são reutilizados ou quando são compartilhados com outros agentes durante a atividade criativa. 
Dependendo do seu uso dentro do contexto da atividade, os fatores materiais podem ser classificados como recursos ou como produtos. No caso dos recursos renováveis, eles podem ser reutilizados na atividade após serem utilizados na geração de produtos. Por exemplo, o uso de modelos de síntese que geram novos resultados sonoros para cada interação (KELLER; TRUAX, 1998) permitindo que um único sistema produza materiais relevantes - neste caso recursos consistentes com a classe sonora definida no modelo - e originais, os sons gerados não são repetições de sons já existentes. Já os sistemas baseados em reciclagem repetitiva - como é o caso da técnica de looping - perdem originalidade após a primeira interação e, portanto dependem da incorporação constante de novos recursos materiais (cf. DAISYPHONE; BRYAN-KINNS, 2004). Nestes dois exemplos, o modelo computacional de geração de dados (modelagem ecológica no primeiro caso, e looping no segundo caso) forma parte dos recursos materiais utilizados durante a atividade criativa. Os sons - gerados a partir da interação do agente (compositor ou usuário do sistema) com o modelo computacional - formam parte dos produtos decorrentes da atividade. No entanto, esse material gerado durante a atividade criativa só poderá ser caracterizado como produto criativo se ele for considerado relevante pelos participantes da atividade. Nesta perspectiva, para que um recurso material se transforme em um produto criativo o agente precisa caracterizar o recurso como sendo relevante e original. A análise de relevância e originalidade está diretamente ligada com recursos cognitivos que estão associados aos processos citados no modelo MM: percepção-análise-síntese. Está caracterização pode ainda estar ligada diretamente com a pregnância dos recursos materiais no ambiente. Ou seja, um recurso material ou uma ação contingencial pode ser tão pregnante e original que se torna relevante para demais agentes, propiciando condições de imitação (mímesis). Caso contrário, o produto material passa a formar parte do que poderíamos denominar de resíduo criativo.

A questão da produção do resíduo criativo vincula-se a duas variáveis: conhecimento dos recursos materiais e consenso entre os participantes da atividade criativa (FERRAZ; KELLER, 2012). Nos sistemas socioecológicos, nos quais há predominância das forças para-fora ou out-group ${ }^{18}$ : há um aumento na variável conhecimento motivando a tendência de reduzir a quantidade residual, já o maior nível de consenso tem o efeito oposto: aumenta a produção residual através do descarte de maior quantidade de material irrelevante. Nos sistemas socioecológicos musicais em que predominam as forças para-dentro ou in-group ${ }^{19}$,, o menor conhecimento dos recursos materiais e cognitivos faz com que haja um aumento na probabilidade de produção de resíduos, mas ao mesmo tempo a facilidade de atingir o consenso - devido à baixa seletividade

\footnotetext{
18 Termo que determina condições em práticas ecológicas: 1) ações de forças externas ao sistema socioecológico. 2) Condição de desvinculação sonora, propiciando condição heterogênea.

19 Termo que determina condições em práticas ecológicas: 1) ações de forças internas ao sistema socioecológico. 2) Condição de aglutinação sonora, propiciando condição homogênea.
} 
dos membros do grupo - atua no sentido oposto, reduzindo as probabilidades de produção de resíduo.

Para confirmar ou refutar a predição de que sistemas onde predominam as forças para-dentro (in-group) são mais eficientes do que os sistemas com maior tendência para-fora, é só medir o tempo da atividade criativa até atingir o nível de consenso necessário para obter um produto criativo. Sobre o nivelamento do consenso em produtos criativos, consideramos uma abordagem complexa. Não há uma "solução" quantitativa para medir e estabelecer parâmetros claros de como o processo ocorre. Isto devido às diversas variáveis cabíveis. Sugerimos que a medição do consenso pode ser realizada à partir de duas vias:

1) Pregnância de recurso material: Como estes recursos são mensuráveis por via temporal, os eventos sonoros que permanecem no sistema apontam para um comportamento de interação com outros agentes. Estes por sua vez quando se apropriam dos recursos, parecem indicar que os agentes entraram em consenso e admitiram tal recurso como relevante para performance/experimento.

2) Mímesis: através da imitação ou repetição (gestual, sonora, técnica) podemos quantificar que o agente atingiu o consenso (no sentido de percepção/análise) e determinou ações de síntese dentro ou fora do sistema.

Se o modelo dentro-fora estiver alinhado, sistemas socioecológicos musicais altamente homogêneos (onde os participantes compartilham campos epistêmicos similares/in-group) produzirão uma grande quantidade de resultados relevantes com pouca geração de resíduo, maximizando o uso do tempo de criação coletiva. Neste contexto os resultados originais serão escassos. Em contrapartida, sistemas heterogêneos (com participantes com grande diversidade de campos epistêmicos/out-group) tenderão a produzir rapidamente resultados originais mas pouco relevantes, aumentando a geração de resíduo. Como a proporção entre material gerado e material descartado é comparável e quantificável, encontramos uma medida indireta do potencial criativo do sistema musical complexo. Podemos afirmar que os recursos materiais podem ser comparáveis e quantificáveis através das mesmas ferramentas analíticas introduzida no consenso entre agente. Quando ocorre a produção dos recursos materiais, podemos apontar quais materiais se tornam pregnantes ou passam por processos de mímesis dentro do sistema socioecológico. Se a quantidade do material gerado for proporcional aos processos de pregnância e mímesis, mantendo os resíduos criativos em uma escala inferior à produção original, temos um mecanismo de análise positiva do sistema. Se a maior parte do material gerado não é pregnante nem propõe condições de mimesis, este se torna resíduo, empobrecendo as condições de criatividade do sistema. 
Complementarmente, a utilização de recursos renováveis pode ajudar no aumento da criatividade do sistema. Neste caso, o MDF sugere que o uso de recursos renováveis impulsiona o sistema para resultados mais consistentes sem aumentar a produção de resíduos. Ou seja, um sistema de geração de recursos materiais originais e relevantes não exige uma alta seletividade para atingir o consenso. A predição experimental é que sistemas que utilizam mais recursos renováveis levarão menos tempo para atingir o consenso, gerando menor quantidade de resíduos criativos.

Concluindo, o Modelo Dentro-Fora fornece um contexto teórico para testar variáveis experimentais vinculadas a dois fenômenos observados em sistemas socioecológicos musicais:

1) a relação entre as características do grupo e os resultados criativos,

2) a relação entre o suporte material/cognitivo e a produção de material residual criativo. A nível individual, esses dois fenômenos podem ser relacionados através do conceito de campo epistêmico. A nível social, a interação entre os campos epistêmicos determina o jogo de forças de aglutinação e de desagregação que dão forma ao processo de criação coletiva em contexto ecológico.

\subsection{Aplicações e Verificação dos Modelos MM e MDF}

Tanto o modelo MM quanto o MDF tem potencial para contribuir no desenvolvimento do marco teórico-metodológico necessário para a consolidação das práticas criativas ecológicas desenvolvidas nesta dissertação. Em linhas gerais, existem duas áreas de aplicação: 1. As propostas que visam o desenvolvimento do suporte para as práticas criativas, recentemente impulsionadas pelos resultados da pesquisa em ecologia sonora; e 2. As propostas voltadas para o domínio específico, com destaque para a relação entre performance/experimento e criatividade musical. O primeiro âmbito abrange diversos enfoques metodológicos - como os padrões de interação e as metáforas de apoio à criatividade (PIMENTA et al., 2014) -, aplicações educacionais fundamentadas na relação entre as perspectivas dialógicas e o design participativo (LIMA et al., 2012), e diversas aplicações artísticas de cunho multimodal (BASANTA, 2010; KELLER et al., 2014, ALIEL, 2013/2014/2015/2016). O segundo âmbito inclui o enfoque ecológico nas práticas criativas musicais abrangendo tanto as manifestações da criatividade computacional quanto a incorporação das fontes sonoras instrumentais. Nesta última proposta se inserem as práticas comprovisatórias (ALIEL et al., 2015). 


\section{Perspectivas Ecológicas em Comprovisação: Abordagens, Intencio- nalidade, Interação e Agenciamento}

Pautados pela discussão dos processos teóricos (sistemas socioecológicos, MM e MDF), nos limitamos a analisar os impactos da comprovisação como vertente artística voltada à ecologia sonora. Faremos levantamentos sobre conteúdos observados durante a produção e execução dos estudos de caso que serão descritos e analisados no capítulo VII. Acreditamos que as descrições dos recursos materiais observados podem ajudar na compreensão de como os estudos de caso se desenvolveram. Conteúdos singulares como as interações dos agentes neste tipo de atividade, seus comportamentos, ações e percepções criaram um plano teórico para práticas ecológicas comprovisadas. Procuramos ainda questionar os limites das diretrizes que determinam uma composição ecológica e como estabelecer elementos que lidam com conceitos complexos de composição e a improvisação.

A partir destes elementos, levantamos hipóteses e buscamos dilatar e argumentar alguns procedimentos ou comportamento observados em comprovisações.

\subsection{Dilatação das Abordagens Metodológicas e Discussão}

No escopo de processos artísticos ecológicos em abordagens comprovisacionais, procuramos traçar ferramentas capazes de trazer um suporte metodológico sobre os procedimentos. Encontramos nos sistemas socioecológicos e nos modelos MM (MANNIS, 2014) e MDF (FERRAZ; KELLER, 2012) um campo hipotético que apresenta características que podem ser utilizadas para investigar as ações criativas comprovisadas com enfoque ecológico em manifestações sonoras instrumentais acústicas e eletrônicas.

É relevante apontarmos que o conceito da comprovisação propõe variantes sobre alguns parâmetros dos modelos citados, principalmente sobre o modelo MM. Embora em nossa aplicação o modelo engloba os processos criativos comprovisacionais, aparentemente seu desenvolvimento inicial analisa unicamente a questão composicional de modo a enfatizar as ações entre tensões e resoluções (acomodações) de produtos, não incluindo ações contingenciais (improvisações).

Entretanto, em um alinhamento entre MM e ecologia sonora é exatamente na emergência de recursos singulares, (não planejados a priori - contingências) durante a performance/experimento, que os modelos se mostram compatíveis. Nesta abordagem não há pressupostos de resoluções de problemas em um conceito tradicional. O que parece haver são relações (multilaterais) entre a emergência dos recursos materi- 
ais disponíveis, os processos de planejamento e as tomadas de decisões (recursos cognitivos).

O modelo MM questiona que havendo fusão de múltiplas forças, é necessário ponderar analiticamente sobre as resultantes das tensões em um aspecto da manutenção, transformações ou resolução destas forças. Embora os procedimentos de manutenção/transformação/acomodação aparentemente tenham sido planejados sob uma ótica composicional, são pontualmente estes eventos que observamos em procedimentos comprovisacionais. A variante mais distinta talvez advenha de que os procedimentos (manutenções, transformações e acomodações) não podem ser engendrados anteriormente, como sugeridos no modelo $\mathrm{MM}$, afinal são os recursos materiais disponíveis e os processos de recursos cognitivos em tempo real que determinarão as consequências dessas ações.

Em uma tentativa de aspecto analítico quantitativo dos processos comprovisacionais citados pelo modelo $\mathrm{MM}$, ou seja, considerando plano de diretrizes (composição) e planos contingenciais (improvisação), foi necessária a utilização do modelo MDF para estabelecer parâmetros comparativos entre as performances/experimentos. Analisaremos as comprovisações desenvolvidas para este trabalho como estudos de caso para tentar discutir as eventualidades contidas neste tipo de manifestação artística.

À priori dividiremos a conceituação do modelo MDF em dois eixos principais que são condizentes com os planos de diretrizes em comprovisações, (conceitos composicionais):

1) Criatividade in loco: recursos materiais disponíveis no sítio;

2) Tecnologia como suporte à criatividade: Ações onde desdobramentos tecnológicos oferecem novos recursos criativos ao cenário;

Ambos os objetos de estudo parecem fornecer diretrizes capazes de estabelecer o design de obras comprovisacionais. Ou seja, promovem condições em que se pode analisar de forma quantitativa: a construção e/ou escolha de materiais e abordagens técnicas sobre este arquétipo de produção. Os dois eixos provavelmente não contemplam todas as possibilidades de design que podem ser incorporadas em comprovisações, mas são suficientes para tratar dos estudos de casos abordados. Todos os estudos de caso utilizam recursos disponíveis in loco que podem ser constatados, selecionados, comparados e delimitados como fonte de material e se apoiam em artefatos tecnológicos para expandir as possibilidades criativas.

Alinhamos as duas linhas de estudo às propostas de modelagem de sistemas socioecológicos. Tanto na proposta de modelagem de síntese ecológica (PMSE) quanto na proposta de modelagem em looping (PL). Acionamos propriedades in loco, como 
escolha dos recursos materiais, utilização de objetos do lugar (place), apropriação do espaço e consideramos a intencionalidade da percepção, análise e síntese como recurso cognitivo. Ambas as propostas também contemplam a expansão das possibilidades sonoras utilizando-se de propriedades tecnológicas tais como processamentos sonoros, síntese sonora e algoritmos estocásticos.

\subsection{Intencionalidade em Processos Ecológicos Comprovisados}

Ao abordar o processo de intencionalidade ou tomada de decisão em comprovisações,, que estão contidos nos sistemas socioecológicos como recursos cognitivos, utilizamos o conceito de heurísticas estéticas como área de estudo no âmbito da investigação em comprovisação com abordagens ecológicas (ALIEL et al., 2015). A heurística estética é uma abordagem da ecocomposição onde os processos cognitivos empregados em decisões não racionais são definidos como a estratégia que ignora parte da informação com o objetivo de tornar a escolha mais fácil e rápida. Há uma discussão sobre as motivações para estreitar as variáveis experimentais envolvidas em estudos de design centrados na criatividade. Em seguida, as heurísticas estéticas são colocadas no âmbito dos atuais esforços de apoio à criatividade, destacando os estudos recentes que visam a criatividade musical cotidiana. Os resultados experimentais apontam para uma lacuna entre as propostas teóricas em criatividade musical e os fatores que impactam as atividades musicais cotidianas. A auto-referencialidade do construto teórico-experimental e a restrição prematura de domínio são duas das limitações apontadas em trabalhos teóricos anteriores [KELLER et al. 2011; LIMA et al. 2012; KELLER et al. 2014]. Keller et al. (2015) fornecem uma definição provisória de heurísticas estéticas, indicando o objeto de estudo e as motivações da proposta.

Em Relational Properties in Interaction Aesthetics: The Turn Music Ubiquitous, Keller et al. (2014) adotam como ponto de partida os avanços teóricos recentes em design de interação e em interação humano-computador [LOWGREN, 2009] para analisar o processo de tomada de decisões nas atividades criativas. Sendo que esses processos apoiam-se em recursos materiais, sociais e cognitivos, conceitos e métodos específicos foram propostos para descrever aspectos da concepção e da materialização das experiências tecnológicas dentro da pesquisa em criatividade. A maleabilidade [pliability - LOWGREN, 2007] e a ancoragem [anchoring - KELLER et al, 2010] são duas qualidades de design que surgiram do impacto das interações entre as práticas criativas ecológicas e o enfoque estético em design de interação. Um exemplo da aplicação de conceitos ecológicos no suporte criativo é a metáfora de marcação temporal $^{20}$ [KELLER et al. 2010; RADANOVITSCK et al., 2011]. Múltiplos estudos de

20 Um método que adiciona gatilhos durante o processo temporal de uma obra. Essas marcações 
aplicação da marcação temporal serviram para exemplificar como as propriedades relacionais podem ser integradas dentro de sistemas para o suporte criativo [FERREIRA da SILVA et al., 2015; FARIAS et al., 2014; KELLER et al., 2013; PINHEIRO da SILVA et al., 2013].

O engajamento, os padrões de comportamento, as formas alternativas de design com combinações inovadoras de materiais e as identidades dos participantes inseridos em contextos culturais específicos são identificados como temas comuns. Dispor-se à criatividade implica em lidar com fenômenos que não foram considerados dentro da perspectiva estética do design de interação. Para estabelecer métodos comuns entre a interação e a pesquisa em criatividade, Keller et al. (2015) discutem as implicações da adoção de propriedades relacionais materiais e de propriedades relacionais sociais como alvos para o trabalho experimental. As propriedades materiais são o foco de duas metáforas de interação: a marcação temporal - mencionada previamente - e a marcação espacial. A marcação espacial consiste na utilização de pistas visuais para determinar as ações dos participantes em atividades criativas musicais [KELLER et al., 2011].

Entendidas como um todo essas três publicações fornecem uma base teórica inicial para abordar o estudo da tomada de decisões nas atividades criativas. Três metodologias foram destacadas pela pesquisa: a avaliação dos produtos criativos, a observação dos comportamentos criativos e da análise dos perfis dos participantes. Para avançar na frente metodológica, esses trabalhos propõem o design de novas metáforas de apoio à criatividade. Os exemplos discutidos em [KELLER, 2015] servem para ilustrar a aplicação musical das heurísticas criativas sugeridas por Amabile (1995). Amabile (1995) compilou uma lista das heurísticas mais citadas para a tomada de decisões no contexto de atividades criativas. Ao invés de focar em procedimentos predeterminados, cinco dos sete itens discutidos por Amabile descrevem estratégias para lidar com a atividade criativa, sem metas predefinidas:

1) Jogue com ideias (WICKELGREN, 1979, apud AMABILE, 1995).

2) Tente gerar hipóteses, analisando estudos de caso, utilizando analogias, respondendo por exceções e investigações incidentais paradoxais (MCGUIRE, 1997, apud AMABILE, 1995).

3) Faça o familiar estranho e faça o estranho familiar (GORDON, 1961, apud AMABILE, 1995).

4) Tente algo contra-intuitivo (NEWELL et al., 1958, apud AMABILE, 1995).

permitem que os agentes tomem consciência de diretrizes em meio a um plano de contingência 
5) (a) Use sessões de trabalho concentrados, em vez sessões de trabalho distribuídos; (b) Comece jogando com a mesma ideia de um número de formas diferentes, antes de entrar nas sessões de ideias geradas; (c) não conte com a sobreaprendizagem de mecanismos de resposta (MEDNICK, 1962, apud AMABILE, 1995).

6) (a) Tente reorganizar os elementos de um problema; (b) faça uma pausa; (c) comece a considerar uma solução que envolva os elementos mais importantes antes de elaborar a solução em detalhe; (d) tente considerar classes de interesses em nome de elementos específicos; (e) Quando a via para alcançar uma meta de sua posição parecer muito longe, o sistema auxilia a procurar formas mais curtas (ANDERSON, 1980, apud AMABILE, 1995).

7) (a) Aplique impossíveis intermediários; ${ }^{21}$ (b) determine o potencial de uma ideia para desencadear novas ideias ao invés de validá-lo (BONO, 1971, apud AMABILE, 1995).

Vemos que desde uma perspectiva mais ampla, não necessariamente focada nos aspectos específicos do fazer musical, mas no suporte para as decisões criativas, ganha importância o processo de preparação da atividade - o que no âmbito desta pesquisa compreendemos como partes composicionais de uma comprovisação. As heurísticas 1, 2, 5, 6 e 7 não propõem como método a definição de um objetivo previamente ao início da atividade criativa (que se constitui em requisito das propostas formuladas por Mailman - intencionalidade - e Hannan - adoção da metodologia vinculada à solução de problemas). Muito pelo contrário, o suporte para as decisões criativas envolveria o engajamento ativo com os materiais e implicaria necessariamente um processo de auto-reflexão.

\subsection{Interação Consensual}

Neste tópico, consideramos a discussão e teorização sobre as principais interações observadas entre os agentes envolvidos em um sistema socioecológico como sendo mais consensual ou menos consensual. À medida que usamos como metodologia o uso de ações comprovisatórias, a interação consensual parece fornecer um dos principais canais de observação dentro do plano contingencial (improvisação). Em outras palavras, na abordagem consensual, as interações consensuais têm a diretriz para a produção de recursos anteriormente não planejados (ações criativas em tempo

\footnotetext{
21 Trata-se de adicionar agentes intermediários que normalmente não existiriam. No foco deste trabalho,
} as entidades gelassenheit. 
real), derivadas das relações entre: agentes performativos, agentes incisos e a entidade gelassenheit (HEIDEGGER, 1966 e KOUTSOMICHALIS, 2011). Os agentes performáticos seriam aqueles que obtiveram treinamento tradicional em música. Estes tendem a buscar a apreensão de recursos materiais tradicionais para o discurso criativo. Os agentes incisos são aqueles que estão imersos no ambiente e podem contribuir com ações criativas, mas não possuem treinamento musical tradicional. $E$ as entidades de gelassenheit são contingentes puros no ambiente que não podem ser medidos ou quantitativamente avaliados, isto é, o erro, acaso ou indeterminação. Na entidade gelassenheit, adaptamos as notas de Heidegger (1966) em uma abordagem ao trabalho sobre o som de Koutsomichalis (2011). Na análise original, Heidegger trabalha no conceito de "permissão" ao experimentar as realidades de uma maneira não representativa ou mesmo incerta, que ele considera ser um mistério. De acordo com Koutsomichalis (2011), o conceito de gelassenheit (no viés sonoro) trata da capacidade de descrever a qualidade particular de uma massa de som. Um conjunto distinto de condições que só através da subjetividade podem ser experimentados. Em nossa estrutura, entendemos o conceito como primordial para práticas comprovisacionais. Todos envolvidos, performers ou incisos são alvos de contingências que trazem incertezas capazes de modificar os resultados finais. Essas contingências podem até ser observadas separadamente, mas é dentro de um contexto complexo, como sistemas socioecológicos que parecem promissores. Este aspecto também se alinha com a perspectiva de desvio, proposta no modelo MM. São as entidades gelassenheit que trazem o caráter de imprevisibilidade observado em paisagens sonoras para o conteúdo comprovisado. Em uma relativização das propostas de escuta e percepção de ambientes de som ecológicos, pode-se entender que todo o ambiente é composto, sendo auto-organizado de forma adaptativa, no entanto, as contingências estranhas produzem resultados suficientes para a completa modificação do sistema Por exemplo, uma árvore com vários pássaros (agentes incisos) nela. Este sistema sócio-ecológico será regido pelos sons dos agentes incisos, suas interações e as percepções do meio ambiente. Se, ao acaso, um trovão (entidade gelassenheit) quebra este sistema, causando a dissipação dos agentes incisos, temos uma mudança total no panorama do sistema inicial. A entidade gelassenheit "trovão" pode até ser validada como um componente orientador desses ambientes, mas não existe nenhuma maneira que outros agentes usem intencionalmente esse recurso. Todos os agentes são afetados pela entidade gelassenheit (quando estão envolvidos em um sistema socioecológico) de forma mais ou menos velada. Da mesma forma, nos sistemas socioecológicos, onde propomos conceitos comprovisados baseados em diretrizes e contingências, ações estocásticas devem ser introduzidas como mecanismos de gelassenheit, permitindo uma semelhança de condições naturais. Acreditamos que, ao introduzir algoritmos estocásticos em sistemas socioecológicos, alcançamos possibilidades satisfatórias ao simular entidades de gelassenheit. 
Em outra condição, é relevante considerar as notas relacionadas ao modelo de MM. Aparentemente, as interações consensuais entre agentes e entidade têm um alinhamento ao pensamento de "percepção-análise-síntese" (modelo MM) e se estendem à aquisição de outros estereótipos, como a incubação (modelo YBM), a interação não-especializada (GLAVEANU, 2013) e lugar (place - RHODES, 1961). Ou seja, é provável que possamos observar as condições em que os modelos citados podem atuar em comprovisações.

Nos agentes performáticos, acreditamos que encontramos interações consensuais ao longo das linhas do modelo MM onde cada agente tenderá a perceber (associar, comparar, classificar), analisar (considerar modelos musicais, estruturas, taxonomias, base de conhecimento) e sintetizar (assimilação, adaptação, incorporação) suas ações. No entanto, é vital ressaltar que as interseções múltiplas entre os outros agentes e entidades podem contribuir, ou não para condições em cada estágio, ou seja, a produção de mais ou menos originalidade/resíduos criativos (conteúdo tratado na frente). Cabem ponderações sobre o processo de incubação (modelo YBM) nos agente performáticos. Entre as ocorrências de eventos, com base nas propostas do modelo MM, isto é a partir do ciclo "percepção-análise-síntese", as condições originadas no plano de percepção e análise não podem ocorrer, afinal, não estão abertas ao plano prévio de síntese. Considera-se a existência de recursos materiais e cognitivos que são percebidos e analisados, mas não são sintetizados naquele momento, sugerindo uma representatividade em outros momentos propícios, de modo que os recursos podem ser indicados nas etapas de incubação. Este conceito pode aparentemente ser usado tanto em planos de diretrizes quanto em ações de contingência, mas, aparentemente, é necessária a intenção de qualificar esta condição. A síntese dos agentes performáticos propõe uma condição de produção de material relevante, no entanto, com pouca produção original (alinhamento ao modelo MDF (FERRAZ; KELLER, 2012)). Os agentes performativos também podem usar ferramentas que podem expandir, restringir ou fornecer (expandir, contrair, desvio em MM) em comprovisações.

Nos agentes incisos, acreditamos que existem interações consensuais que abrangem planos semelhantes aos agentes performativos, no entanto, acredita-se que, no conceito de análise, há uma variação significativa. Subdividindo esses dois grupos, delimitamos que os agentes performativos correspondem principalmente a indivíduos com alguma formação musical, onde a análise de ação será diretamente proporcional ao conhecimento adquirido. Os agentes incisos podem apresentar heterogeneidade em conhecimentos musicais ou treinamento. Ou seja, nesta subdivisão estão aqueles indivíduos sem antecedentes musicais que podem trazer contribuições criativas para o trabalho, gerando a interação não especializada proposta por Glaveanu, (2013). No entanto, não existe de fato a limitação de que apenas indivíduos sem treinamento musical pertencem a esse grupo. Consideramos apenas possível analisar esta divisão. Este 
não é um modelo fechado, várias possibilidades do conhecimento musical podem ser adaptadas aos agentes incisos, tudo dependerá da análise específica de cada trabalho sonoro. A questão da originalidade é amplamente compreendida. (em alinhamento com as propostas do modelo MDF (FERRAZ; KELLER, 2012)). Os agentes incisos também podem usar ferramentas que podem expandir, restringir ou fornecer translação (estender, contrair, "desvio" em MM) em comprovisações.

$\mathrm{Na}$ metáfora da entidade gelassenheit, de uma perspectiva de percepçãoanálise-síntese, aparentemente, encontramos algumas formas de relacionamento entre elas. Esta entidade tem como princípio, em nossa concepção, a instabilidade e a indeterminação de aspectos sonoros no meio ambiente. Nesse cenário, as entidades contemplam aspectos de análise e síntese, mas são altamente relevantes para os processos de percepção. Ou seja, essa perspectiva está ligada a processos que podem até ser observados (percepção), mas não podem ser planejados, calculados ou mesmo reproduzidos sintomaticamente em uma comprovisação.

Portanto, alinhamos as entidades de gelassenheit com procedimentos de translação (modelo MDF) ou desvio (modelo MM). Ou seja, nas comprovisações, é a desterritorialização das massas de som um dos principais métodos para o desenvolvimento de condições criativas. De acordo com Mannis (2014):

Tudo o que está efetivamente territorializado está em equilíbrio e harmonia em relação ao território (meio no qual se encontra). Um fragmento extraído de um território porta fluxo(s) característico(s) que podem remeter à sua origem. Um fragmento desterritorializado, ao atravessar ou incidir sobre outro território portando seu próprio fluxo, pode ser aceito ou ignorado/rejeitado. Se aceito, ou seu fluxo já se encontrava codificado no novo território ou foi codificado por este através de processos de acomodação e equilibração, de maneira que o excerto desterritorializado e o novo território se adequaram um ao outro. Para a adequação e equilibração, podem ocorrer variações/mudanças/movimentos na forma, na estrutura ou no material componente de ambas as partes. De maneira que um dado fluxo, se estiver codificado em um território, nele circula livremente. (MANNIS, 2014 p.200)

Considerando o quadro proposto por Mannis, podemos assumir que, nas comprovisações onde temos planos de diretrizes (composição) e planos de contingência (improvisação), a acomodação e o equilíbrio de material é um fator preponderante para os recursos, ou seja, as condições de translação ou desvio em ações criativas originais.

Como mencionado anteriormente, tanto os agentes performáticos como os incisos podem produzir desvios capazes de criar condições originais em comprovisações. Conforme demonstrado no modelo MDF, aparentemente os agentes performáticos tendem a produzir menos desvios, já que sua base de conhecimento (knowledge base) leva a processos técnicos de rotina ou processos de mímesis. 
No entanto, acreditamos que os agentes incisos podem produzir mais material descaracterizado do contexto subjetivamente condicionado, produzindo mais possibilidades de desvios ou produtos originais, como visto em MDF (FERRAZ; KELLER, 2012).

[...] músicos experientes têm acesso a uma grande quantidade de material (maior conhecimento), mas esse material gera muito descarte por conta da alta seletividade (maior consenso, maior consistência). Já participantes leigos produzem material original que não é relevante devido à falta de um histórico de interações com o ambiente (menor conhecimento) ou com o senso comum (menor consenso). Mantendo a ideia de que quem participa na atividade criativa é quem escolhe o material, no caso dos leigos, a interação limitada com o material reduz as probabilidades de atingir resultados consistentes e também limita a relevância desses resultados. Isso aumenta as probabilidades de produzir lixo. Paralelamente, a facilidade para chegar ao consenso (motivada pela baixa seletividade e relacionada ao tempo reduzido de interação com os outros membros do grupo) reduz a quantidade de lixo. Já no caso dos profissionais, a alta seletividade (proporcional ao maior nível de consenso e ao maior tempo de interação com os outros) aumenta a quantidade de lixo. Ao mesmo tempo, o acesso fácil a muito material aumenta as probabilidades de resultados relevantes e consistentes, reduzindo a quantidade de lixo [... ] (FERRAZ; KELLER, 2014).

Embora agentes incisos possam ter essa capacidade de originalidade, as condições de desvio produzidas por eles podem não ser agregadas por agentes performáticos em ações criativas. Afinal, a condição de desvio gerada pelos agentes incisos pode ser inesperada até não compilar as codificações dos agentes performáticos, que acabam por perceber, analisar e não sintetizar esse material. Em outras palavras, podemos observar que as ações de agentes incisos em várias instâncias não se desenvolvem por escolhas intencionais dos agentes performáticos. É neste paradigma que as entidades gelassenheit podem se tornar significativas nas comprovisações. Como Mannis propõe, o desvio pode ou não estar pregnante à massa de som. Tudo dependerá da sua codificação para os envolvidos. No entanto, ações como o erro, a incerteza e o inesperado têm alta taxa de pregnância, criando ações que provavelmente não podem ser resolvidas, na melhor condição, adaptadas.

Por exemplo, um violinista realiza um concerto. Este concerto já foi realizado por este músico dezenas de vezes. Digamos que durante uma performance específica, uma corda do violino se rompe. Ao que tudo indica, mesmo com um alto grau de conhecimento sobre a obra, o acontecimento inesperado (rompimento da corda) produzirá condições únicas para as ações do violinista. Tudo dependerá do processo de percepção-análise-síntese antes que este novo cenário ocorra. $O$ violinista poderia parar a peça, continuar sem essa corda e assim por diante. Não há como presumir 
quais ações ocorrerão, mas podemos entender que o indivíduo se adapta a essa nova situação. As entidades de gelassenheit são tão voláteis e pregnantes que mesmo nosso músico experiente (exemplo) não será capaz de se preparar no caso de a condição inesperada ocorrer de novo. Não há mecanismos que apoiem o planejamento neste quadro de imprevisibilidade.

A interação consensual está diretamente ligada a um tipo de troca de material e/ou relação entre agentes. Ou seja, quando consideramos uma interação mais consensual, ressaltamos que a relação entre os agentes envolvidos têm alguma característica que permite algum nível de relacionamento com os recursos materiais ou cognitivos na performance. Neste contexto, qualquer diretriz (um estilo musical, um motivo, uma propriedade sonora) permite que os agentes entrem em "estágios de concessão", ou passem de ações não controladas à controladas (intencionalidade). Numa estrutura onde a produção material não é consensual, existe uma produção extensiva de material novo que não é regido por uma diretriz (um estilo musical, um motivo, uma propriedade sonora).

Esta "diretriz consensual" não surge necessariamente antes (plano de diretrizes), ela pode ser estabelecida na performance sem qualquer comunicação verbal, apenas admitindo o grau de interesse no material (pregnância). Com a diretriz uma vez estabelecida (maior interação consensual), a produção de material original tende a cair, aumentando a seletividade do material a ser usado e descartando mais resíduos, afinal, o conteúdo original não será amplamente utilizado. Por exemplo, em uma improvisação idiomática, os recursos materiais que extrapolam o idioma são considerados como originais, contudo, terão pouca pregnância. Sem diretrizes estabelecidas (menor interação consensual), a produção do material torna-se variável e a maioria será original, gerando pouco resíduo, afinal, o material original será amplamente utilizado. Por exemplo, em improvisações livres, os recursos materiais são ilimitados, permitindo pouca seletividade maior originalidade.

Desta forma, propomos duas condições de interação:

- Maior Interação Consensual: produz mais material não original, (aumento residual). (Mesma linguagem, maior seletividade de material);

- Menor Interação Consensual produz material mais original (diminuição do residual) (Linguagem variável, menor seletividade de material);

Em suma, acreditamos que os agentes performáticos interagem uns com os outros com maior "diretriz de concessão", com os agentes incisos e com as entidades gelassenheit na forma menos concessiva. Os agentes incisos interagem uns com os outros, com agentes performáticos e com as entidades gelassenheit de forma consen- 
sual pequena ou média. $\mathrm{E}$ as entidades de gelassenheit interagem de forma nula à concessão. Esta condição determina a questão da relevância e originalidade (validação de atividades criativas) e resíduo criativo. Conforme mencionado anteriormente, a pregnância do material está aparentemente relacionada à codificação dos envolvidos. Quanto maior a pregnância, maior a relevância e menor a originalidade, e quanto menor a pregnância, menor será a relevância (resíduo criativo) e maior a originalidade.

Ferraz; Keller (2014):

Em relação à produção de lixo criativo, as forças de aglutinação (paradentro) e de desagregação (para-fora) podem ser exemplificadas comparando uma criança improvisando com um músico de orquestra improvisando. A criança gera muito material original, mas a maioria desse material é irrelevante. As chances de o músico gerar material original são baixas, mas geralmente o material é relevante. A mesma ideia se aplica aos grupos de participantes em atividades criativas. Um grupo de músicos iniciantes gera muito lixo. ${ }^{22}$ Progressivamente, na medida em que as escolhas são afinadas, o grupo pode reduzir maior quantidade de material irrelevante (FERRAZ; KELLER, 2014: 6).

É relevante ressaltar que, neste mecanismo de análise proposto, consideramos a questão quantitativa. Não consideramos material relevante ou irrelevante com base em questões subjetivas, e sim na capacidade do material permanecer presente. Se for pregnante, nós adotamos como relevante, se não houver pregnância, consideramos isso irrelevante. Desta forma, tentamos apresentar o resíduo criativo não como uma forma depreciativa, mas apenas como um material que foi descartado, mas que pode ser reutilizado ou não.

22 Em publicações mais recentes, alteramos de "lixo criativo" para o resíduo criativo, para não causar uma relação de desvalorização com o tipo de material. O conceito geralmente trata de materiais que surgem em ambientes criativos, mas não são usados e são descartados. O termo inicial refere-se à possibilidade de reutilização de materiais - reciclagem. 


\section{Estudos de Caso}

Do ponto de vista dos processos teóricos levantados durante os capítulos iniciais, consideramos desenvolver performances/experimentos que tentam em geral unificar os conceitos de comprovisação ecológica em estruturas práticas de caráter artístico. Todos os estudos de caso incluem a estruturação de ferramentas para mediar práticas ecológicas de forma composta e improvisada. Utilizamos a metodologia da comprovisação para estabelecer o plano de diretrizes e o plano de contingências em design artístico. No aspecto da forma, as comprovisações ecológicas baseiam-se em sistemas socioecológicos com ênfase em dois aspectos principais: síntese ecológica (expansão de possibilidades sonoras usando interfaces tecnológicas em conflito/acomodação ao som ambiental) e looping (condição de repetição de características sonoras em estado macro, possibilitando assemelhação do som). Usamos subdivisões para determinar os principais agentes, sendo: performáticos, incisos e entidades gelassenheit. Os planos de diretrizes serão organizados com regras (específicas ou gerais), organizando tempo, espaço e parte dos recursos materiais, sempre permitindo que as contingências sejam introduzidas no sistema e permitindo desvios para ações mais ou menos criativas. As regras geralmente incluem a interação entre agentes, intencionalidade, fluxogramas de opções, o design de ferramentas tecnológicas (algoritmos), modificações ou intervenção no meio ambiente (espaço). As contingências giram em torno da diminuição da intencionalidade, causalidade ou imprevisibilidade. Utilizamos dois modelos analíticos (MM e MDF) para discutir abordagens de elementos qualitativos em comprovisações, tais como relatórios de observação e análises de questionários semi-estruturados. Além dos elementos quantitativos, como pregnância sonora, caos e ordem dentro do sistema e resíduos criativos. Finalmente, discutiremos as possibilidades de incluir a improvisação em práticas ecológicas, suas viabilidades, conjeturas e deficiências.

\subsection{Estudo de Caso 1: Projeto Destino Pirilampos}

O principal objetivo deste projeto foi habilitar a manipulação de fontes de som e interatividade, a partir de sons localizados remotamente através da transmissão de áudio. A inspiração para este projeto foi a imagem de uma fonte de luz que atrai insetos voadores (no nosso caso, conteúdo sonoro). ${ }^{23}$

O agente performático nesta metáfora representa a fonte, que atrai, manipula e transmuta recursos materiais e cognitivos. Habilitando um metasoundscape (ALIEL; FORNARI, 2013). Esta troca de informações de som entre ambientes e agentes contidos em diferentes locais alinha-se aos princípios de PMSE (proposta modelagem

23 A performance pode ser visualizada em: https://www.youtube.com/watch?v=xtxr2XMaM18 
de síntese ecológica), como inicialmente definido por Keller (2004) e expandido neste trabalho.

A PMSE é aplicada através de processos de síntese de som e interação a distância entre agentes e recursos (materiais e cognitivos) no meio ambiente. Cada interação gera um evento sonoro localizado no tempo e no espaço físico e cibernético. Essa troca entre agentes e recursos materiais e cognitivos altera o estado do organismo e do material, adaptando os objetos característicos às necessidades desses agentes, forçando-os a mudar seu comportamento de acordo com o perfil do nicho ecológico.

No âmbito da PMSE, existem dois tipos de estratégias de interação entre intérprete e ambiente:

1) a aplicação de nichos artificiais (não são encontrados na natureza)

2) a exploração de recursos naturais (os canais naturais de interação entre seres humanos e nichos ecológicos) (BARREIRO; KELLER, 2010).

O conceito de canais de interação ou affordance caracteriza-se pelas relações de interpretação de som entre cada fonte sonora e as formas de percepção dos agentes (recursos cognitivos). Tais formas de percepção podem surgir de vários fatores, tornando a experiência perceptiva única. Esta ligação referencial pode ser entendida como um fluxo de informações entre a fonte de som e sua origem. Em Destino Pirilampo, este fluxo é conduzido pelo agente performático que às vezes torna essa associação clara, enquanto outras vezes essa associação parece se dissolver, perdendo o vínculo referencial entre o som e a fonte.

Em resumo, o projeto Destino Pirilampo propõe combinar várias paisagens sonoras distintas e distantes em uma nova localização, ou seja, em uma nova paisagem sonora. Assim, como um artifício metalinguístico, Destino Pirilampo gera uma nova paisagem sonora constituída de paisagens sonoras. A representação aqui proposta consiste em uma metáfora para o retorno de fontes de som às suas origens, paradoxalmente, em uma nova paisagem sonora. A estrutura deste metasoundscape (ALIEL; FORNARI, 2014) emerge da união de várias paisagens sonoras heterogêneas e gera uma condição homogênea que transcende a limitação de suas localidades físicas de origem. Deve ser esclarecido que as paisagens sonoras são entidades de som dinâmicas e voláteis (ou recursos voláteis - KELLER, 2014). Uma vez gravada, uma paisagem de som revela um corte bem delimitado de um evento dinâmico. A gravação de uma paisagem de som é um registro de um fenômeno complexo que ocorreu no passado no momento da gravação (WESTERKAMP, 2002). Não é um fenômeno auditivo dinâmico. Gravar uma paisagem sonora lembra uma fotografia de uma paisagem natural, por exemplo. Embora a fotografia registre a paisagem, ela não entende toda 
a complexidade em mudança de uma paisagem. Da mesma forma, uma gravação de uma paisagem de sonora corta apenas um momento e não toda a complexidade de tal ambiente. O termo "composição da paisagem sonora" geralmente se refere a uma forma de composição que usa sons gravados de paisagens sonoras.

O projeto Destino Pirilampo apresenta uma variação deste paradigma, buscando desenvolver uma comprovisação baseada em eventos sonoros que ocorrem em tempo real. Ou seja, o trabalho usa a captura em tempo real de paisagens sonoras que são transmitidas e "mix-improvisadas" em um único ponto por um agente performático. Cada evento em paisagem sonora se desenrolará em um novo evento em metasoundscape. Desta forma, Destino Pirilampo cria desafios tanto em relação à improvisação (tipo de material que será manipulado na performance, em analogia com os conteúdos da entidade gelassenheit e em relação à modificação da paisagem sonora, que receberá a informação amalgamada. ) Nestas duas linhas:

\subsubsection{Recursos Materiais e Métodos (Plano de Diretrizes)}

Destino Pirilampo tem apenas recursos eletrônicos, afinal é uma peça para live electronics.

\subsubsection{Recursos Materiais Eletrônicos}

Para determinar as condições em que o trabalho foi estruturado, é importante dividir o nosso argumento em duas partes: uma sobre os planos de diretrizes e outra sobre os planos de contingência (ALIEL, 2016). Como plano de diretriz, algoritmos em Pure Data (PD) foram desenvolvidos para obter um sistema robusto o suficiente para receber, analisar, processar/sintetizar e controlar o conteúdo de som massivo. Utilizamos uma variedade de projetos para fazer com que os modelos computacionais se comunicassem. No entanto, descreveremos apenas os dois principais modelos que estão interligados, o que é consistente com as propostas desta pesquisa

O primeiro projeto recebe as informações de som provenientes do software VolP (voz sobre protocolo de internet), neste caso, o Skype, e o transporta para o software PD, onde pode ser processado em tempo real.

Uma nova paisagem de som é gerada de forma virtual através da mistura de múltiplas paisagens sonoras, criando um ambiente volátil e mutável que chamamos de metasoundscape (ALIEL; FORNARI, 2014). O diagrama a seguir demonstra como o sistema macro de Destino Pirilampo funciona.

Usuários em diferentes locais usam dispositivos conectados à Internet que capturam o som de suas paisagens sonoras em tempo real e enviam-nas através do software Voip (skype). O software VAC (virtual audio cable) conecta o software VoIP 
com o software Pure Data. O áudio das paisagens sonoras passa pelo processamento ao interagir com Pure Data e gera o metasoundscape.

Figura 5 - Diagrama do fluxo ocorrente durante a performance de Destino Pirilampo
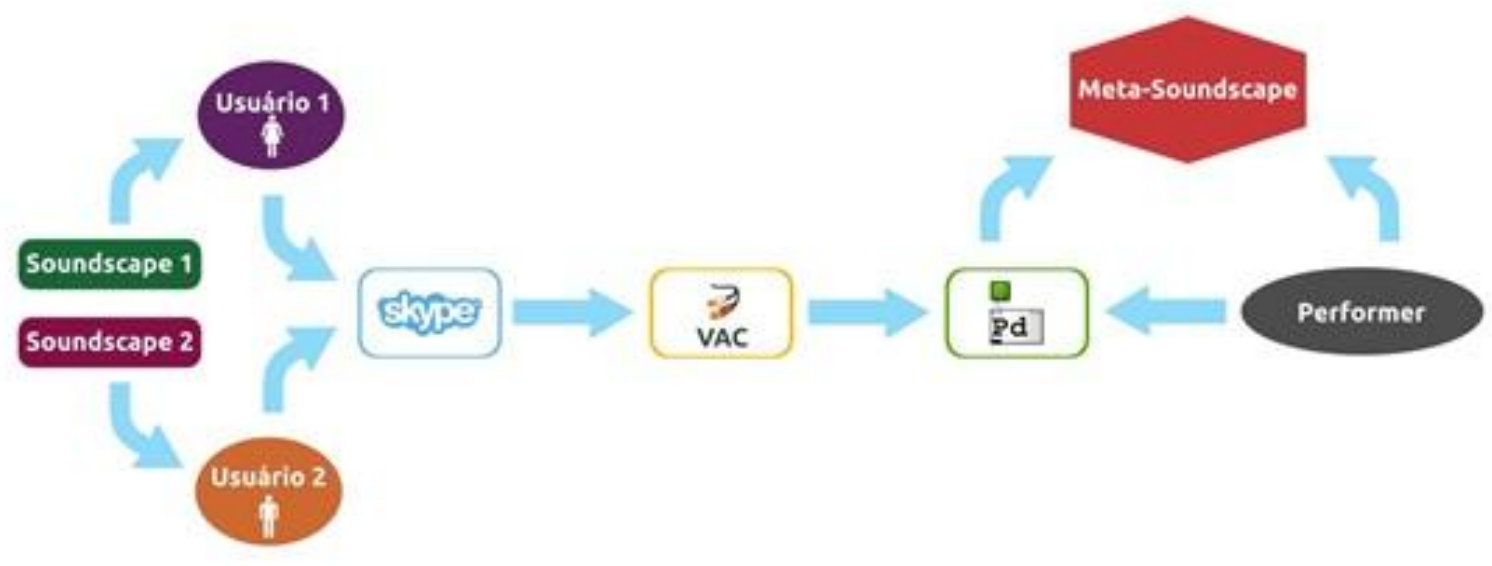

O segundo design é responsável por capturar os gestos do performer por uma webcam. Este algoritmo permite que os gestos humanos modifiquem os padrões de mixagem no processamento. A estrutura suporta um procedimento de captura visual que busca associar variações de som do metasoundcape com um parâmetro gestual associativo. Ao usar uma webcam para capturar os gestos do performer em uma visão geral dos movimentos, propomos que esse tipo de captura forneça dados que irão modificar os processos sonoros e visuais (o que será melhor explicado nos recursos cognitivos do item). Este procedimento consistirá em dois padrões metodológicos possíveis em relação às diretrizes:

1) A preparação anterior para a performance envolvendo: recorte, foco, filtros, direção de captura, iluminação e etc., tendendo a um plano de diretrizes alinhado com a modificação do espaço.

2) Uma vez que existe um tamanho mínimo/máximo (diâmetro, altura) de captura pelo equipamento, os conteúdos que entrarão neste campo podem ter um caráter de intencionalidade. Embora os gestos dos performers não sejam capturados com precisão suficiente para desenvolver "técnicas" para controlar o instrumento com controle significativo, ele ainda possui padrões de escolha, tais como: ficar parado, mover-se com apenas o corpo ou apenas partes dele, aproximar ou distanciar da webcam, estar presente ou não na frente do dispositivo, etc.

Todos esses modelos podem ser entendidos aqui como procedimentos de composição e estão associados com as notas sobre comprovisação feitas por MAILMAN 
(2010 apud ALIEL et al., 2015). Entendemos que esses algoritmos, uma vez produzidos, testados e analisados, são improváveis de serem alterados, tornando este processo especificamente inerte no sentido da prática artística.

\subsubsection{Plano de Contingência e Modelagem Socioecológica}

É válido apontar que existe um processo de improvisação que ocorre paralelamente ao processo de composição em Destino Pirilampo. Em outras palavras, embora o processo de composição (algoritmos) esteja funcionando e seja fundamental para o desenvolvimento da peça, o performer não precisa se dedicar ao processo de composição, limitando-se a concentrar-se na percepção e na capacidade de improvisar.

A prática de contingência de Destino Pirilampo gira em torno das adaptações do agente intérprete, misturando as diversas paisagens sonoras e os conteúdos capturados e enviados por outros agentes. Todo o processo de tomada de decisão por parte dos agentes exige que eles estejam atentos aos recursos materiais e cognitivos existentes. Os agentes selecionarão os diferentes tipos de materiais através da percepção em dois níveis: 1) percepção de relevância ou pregnância. 2) adaptabilidade à escolha/captura. Ambos são compatíveis com os recursos cognitivos dos sistemas socioecológicos.

O agente performático, por sua vez, ainda usará recursos cognitivos para determinar qual material é mais ou menos relevante para um quadro de massa de som denso. Ou seja, quanto maior a quantidade de recursos materiais enviados, maior o desgaste da concentração, adaptação e tomada de decisão que o agente poderia ter. Todos os agentes estarão à mercê das contingências de entidades gelassenheit mais ou menos veladas. Inclusive, os agentes que capturam e enviam recursos serão envolvidos em materiais dinamicamente novos, não permitindo que um processo de planejamento seja implementado (plano contingencial). $O$ agente performático, por sua vez, terá toda uma gama de novos recursos materiais em cada instância, neste sentido a produção residual é grande, projetando que a improvisação ocorre através da seleção de material no sistema final.

\subsubsection{Instâncias (similaridades) e Observação de Interação entre Agentes}

Com o objetivo de apresentar os resultados do processo criativo de Destino Pirilampo, apresentamos a perspectiva de um agente performático buscando construir mecanismos para uma nova sonoridade através de gestos lúdicos e intuitivos, mixando diversas paisagens sonoras. O sistema algorítmico desenvolvido permite empiricamente, isto é, através da experimentação gestual-perceptiva, o desenvolvimento do que sugerimos ser um repertório de gestos capazes de manipular intencionalmente o resultado sonoro. Em uma associação formal com os sistemas socioecológicos, enfatizamos 
que a construção das instâncias resultantes de Destino Pirilampo é caracterizada pelo artista que, através de uma abordagem (recursos cognitivos) interpreta os resultados da paisagem sonora, capturando-os e retornando ao local de performance, fornecendo uma paisagem metasoundscape que entre em harmonia ou conflito com a paisagem sonora real existente.

Nesta perspectiva, podemos indicar o surgimento de dois locais que ocupam o mesmo espaço, mas serão entendidos de maneiras variáveis. Os sons naturais do lugar (paisagem sonora) onde a performance acontece e os sons processados eletronicamente (PMSE) que se misturam com sons ambientais.

\subsubsection{Recursos Cognitivos}

Tratamos o conceito de performance (dentro deste estudo de caso) como empírico, uma vez que a webcam capta os sinais gestuais produzidos pelo artista transformando o produto final. $\mathrm{O}$ agente performático, portanto, durante a performance, reconhece quais gestos ele considera aceitáveis para a prática artística e propõe intencionalmente a repetição ou abandono (recursos cognitivos), fornecendo uma série de gestos comportamentais.

Os recursos materiais são então selecionados com base em escolhas intencionais de aplicação ou não. Embora as ações intencionais gerem dificuldades, (afinal o recurso cognitivo terá de ser escolhido ou descartado em tempo real), associamos esses eventos às condições improvisadas que permitem lidar com o problema em tempo real. Destino Pirilampo procura permitir ao performer a liberdade de improvisação através de gestos intuitivos que são capturados por uma webcam que propõe mudanças sonoras e visuais na obra.

A priori, acreditamos que não há imposição ou necessidade de movimentos predefinidos específicos como mecanismo de gatilho para modificar os padrões do sistema. É, portanto, necessário adaptar-se às percepções e gestos intuitivos durante o processo (recursos cognitivos). Este procedimento tem grandes limitações, tanto na repetição de gestos ou na determinação de padrões significativos, como também nas variações sonoras/técnicas que podem ser empregadas. Ou seja, as possibilidades de selecionar, manipular e controlar o processamento sonoro e visual em tempo real tornam-se limitadas. Afinal, não há um bom desenvolvimento técnico para que o artista tenha controle completo sobre o tipo de procedimento que ele deseja usar. Esses aspectos são consistentes com casos de precariedade (IAZZETTA, 2015). Nossa seleção para um modelo de captura precário é consistente com o preceito de adicionar contingências puras (entidades gelassenheit) ao sistema. O procedimento de improvisação nesta perspectiva, não só questiona os desejos estéticos do performer, mas sua adequação técnica e criativa a situações que ele não controla. Em certa medida 
deste conceito, os planos de contingência tratam tanto da extensão da técnica como da linguagem musical. Neste tipo de proposta comprovisacional, admitir um plano de contingência permite que qualquer som seja usado como recurso material em uma performance. No entanto, existem alguns aspectos comuns entre os dois tipos de prática: ao usar um instrumento acústico tradicional, por exemplo, qualquer performer está limitado ao seu conhecimento prévio sobre o instrumento, mesmo que ele use técnicas estendidas ou adicione recursos de material eletrônico. Uma vez que essas técnicas são usadas, elas são incorporadas na base de conhecimento (knowledge base) do artista (PRESSING, 1998).

No contexto da nossa proposta, uma vez que não é possível controlar ou conceber "o que é o instrumento", é improvável que um repertório técnico seja estabelecido e melhorado. É importante notar que, mesmo que o intérprete tente repetir meticulosamente os gestos, os resultados tendem a ser variáveis. Este aspecto produz um nivelamento entre músicos e indivíduos não musicalizados. Afinal, não há limitações técnicas instrumentais ou barreiras sócio-psicológicas (em um ambiente musical tradicional, um indivíduo não musicalizado pode se achar incapaz de improvisar) para a ação improvisada. Neste universo, podemos sugerir que o plano de contingência ocorre no contexto da intenção. No entanto, o agente performático não tem controle total sobre os resultados, afinal, o problema de controle nesta comprovisação está vinculado a um processo no qual a máquina não pode fazer leituras precisas dos gestos performáticos. Os recursos cognitivos baseados na intencionalidade são suportados por escolhas estéticas com base no tipo de ambiente em que a performance está contida. A precariedade da captura via webcam tem um impacto intencional no caráter final da peça, afinal, aceitamos a ausência de controle total proporcionando ações imprevisíveis (entidade gelassenheit) em integração com as ações do agente. Esse fator pode ser associado aos processos de experimentação artística, segundo lazzetta (2015):

[... ] a precariedade, que se expressa pela admissão de procedimentos, técnicas e tecnologias que implicam na geração de instabilidade, erro e ruído. Mesmo quando não é tomado como projeto poético, nessas produções artísticas o precário é assumido como contingência e pode conviver com aquilo que é estável e consistente. (IAZZETTA, 2015, p.04).

Seguindo o mesmo tipo de raciocínio, temos recursos cognitivos em um plano sonoro que inevitavelmente alcançará o agente performático. Procedendo com a mesma analogia mencionada acima, no caso de improvisação idiomática ou livre, o improvisador pode premeditar pelo menos parcialmente, sua intervenção sonora. Ao planejar uma alta freqüência em um instrumento acústico, é provável que o som emitido se assemelhe ao que o performer imaginou. Mesmo nos casos em que há algum tipo de 
modificação do instrumento acústico (preparação), que de alguma forma poderia alterar o domínio anterior do improvisador, em um processo de tentativa e erro, o improvisador provavelmente atingiria seu objetivo de tocar a alta freqüência. Considerando a questão da improvisação em live electronics que usa algoritmos, por mais complexos que sejam, o performer provavelmente poderia usar estratégias semelhantes às do improvisador de instrumentos acústicos já mencionados.

\subsubsection{Relações Permanentemente Estruturais (Natureza - Criatividade); Relações Permanentemente Não-Estruturais - Resultado de Ações Performáticas}

Em certo sentido, Destino Pirilampo é uma paisagem sonora "imaterial" (uma vez que não possui uma origem real) que habita o ciberespaço. Nesta visão, o agente performático improvisa a construção desta nova sonoridade através de gestos lúdicos e intuitivos, mixando-os. O sistema desenvolvido permite empiricamente, isto é, através da experimentação gestual-perceptiva, o desenvolvimento do que podemos sugerir como um repertório de gestos capazes de manipular intencionalmente, mas imprevisivelmente, o resultado sonoro. Nós tratamos este mecanismo como empírico porque a webcam capta os sinais gestuais produzidos pelo agente performático transformando o produto final. Desta forma, o agente durante a performance reconhece quais gestos ele considera aceitáveis para a aquisição artística e propõe intencionalmente a repetição ou o abandono dos mesmos, proporcionando uma série de gestos. Através da interatividade, há uma adaptação dinâmica à estrutura da peça.

Nesse sentido, podemos apontar que todos os indivíduos envolvidos no ambiente comprovisatório podem, em certo sentido, modificar os padrões finais do sistema. Devido à volatilidade do ambiente comprovisatório, tanto os agentes incisos das paisagens sonoras enviadas quanto os agentes incisos no local do metasoundscape podem produzir fenômenos capazes de alterar o resultado. Afinal, o material a ser utilizado consiste principalmente das inter-relações entre os agentes e os recursos cognitivos e materiais, tornando tais modificações viáveis como sugerido nos sistemas socioecológicos.

Como Destino Pirilampo usa sons capturados em tempo real a partir de uma paisagem sonora, não há nenhuma maneira para o agente performático assumir o que o som terá como matéria-prima. Além desse fator, o som nunca pode ser repetido. Digamos que durante uma performance, um pássaro cante e este som integra a obra. Nesse caso, o performer não pode contar com uma repetição ou mesmo a não intrusão deste tipo de material. O máximo que pode realizar em tempo real é cortar ou minimizar a fonte de som. No entanto, pelo menos uma vez essa fonte de som entrará no ambiente de performance. Encontramos, portanto, um plano onde esse tipo de agente tem pouco controle sobre o meio ambiente e suas ações. Portanto, tenderá a encontrar soluções 
criativas com um baixo tempo de planejamento. Cada novo evento na paisagem sonora, um novo desdobramento torna-se uma variável para a performance.

Acreditamos que, com alguma experiência, o agente pode desenvolver algum nível de familiaridade com os eventos. No entanto, o ambiente será diferente dos ambientes da improvisação idiomática ou livre. Por exemplo, o agente pode assumir corretamente que o pássaro repetirá seu canto e usará esse evento em sua performance. No entanto, não é possível deduzir quando e como esse som será reenviado.

Em outra linha de discussão, mencionamos a questão da mutação da paisagem sonora em um metasoundscape, devido à recepção das outras paisagens sonoras transmitidas via streaming. Este "novo ambiente" tem seu conteúdo originado de várias possíveis trocas de som. Grande parte do material sonoro essencial para a construção deste metasoundscape vem dessa troca de material sonoro. Essa reciprocidade ocorre no ciberespaço que está sendo usado pelos agentes, onde as paisagens sonoras enviam recursos materiais na forma de áudio em tempo real e são processadas e mixadas em um único ambiente.

É interessante notar que em todas as paisagens sonoras ativas, qualquer mudança é capaz de transformar o sistema final. Como o metasoundscape é o resultado de múltiplas paisagens sonoras em relações/conflitos, qualquer estrutura de som é altamente modificável e volátil, permitindo que os metasoundscape se desenvolvam de forma não linear. Assim, cada novo evento pode gerar desenvolvimentos imprevisíveis. Outra questão relevante é que, a partir de um conceito de "mixagem" de paisagens sonoras, um ambiente sonoro é único, e improvável em condições naturais.

Destino Pirilampo é, portanto, a tentativa de desenvolver um ambiente comprovisado multimodal onde as programações de algoritmos definem o processo de composição, enquanto eventos ambientais são apresentados como materiais maleáveis e disponíveis para contingências em tempo real. 
Figura 6 - Imagem de um momento da performance do projeto Destino Pirilampo.

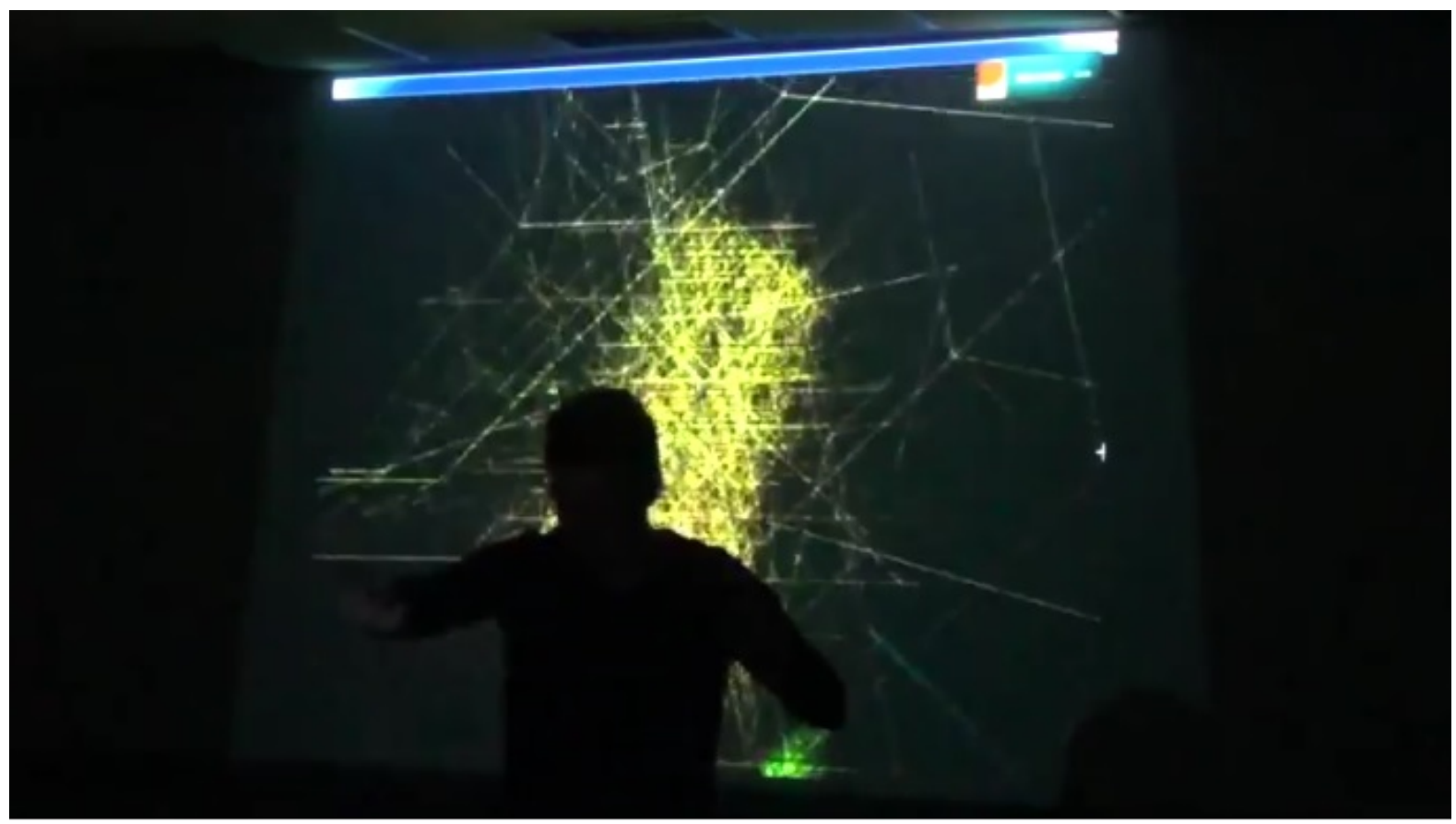

\subsubsection{Comportamento: (MM) - Processo Ecológico/Sociológico/Atividade}

Nesse sentido qualitativo, os participantes têm três opções criativas baseadas no MM: 1. alterar o metasoundscape através de gestos interativos. 2. Modificar os parâmetros do som, especificamente a dinâmica e as alturas (através de gestos intuitivos), ou 3. não alterar nada (a ausência de interação implica a continuidade dos parâmetros previamente definidos). As três condições usam recursos de percepção-análise-síntese, onde o agente considera a potencialidade dos recursos cognitivos para estabelecer parâmetros gestuais apropriados às escolhas intencionais de ações.

Embora o MM determine que a imitação é um dos principais mecanismos de geração de material, Destino Pirilampo não encontra este argumento. Como os recursos materiais são imprevisíveis e existe uma limitação tecnológica (precariedade) da captura de webcam, os gestos desenvolvidos não são gerenciados pela imitação, mas pela adaptabilidade. Isso pode revelar-se um dos elementos importantes para a expansão do modelo Mannis e para a pesquisa em comprovisação ecológica.

Não que essa imitação não possa ser observada, mas torna-se de pouco valor para resolver os problemas apresentados. $O$ agente está condicionado a resolver o problema através de uma adaptação gestual às condições apresentadas e não há soluções semelhantes, portanto não há como repetir ferramentas (imitação de gestos) 


\subsubsection{Entidade de Interface: (MDF) Impactos de Fontes Externas e Internas}

Aplicando o MDF, podemos observar um alto teor de novos recursos materiais, afinal, todos os envolvidos estarão compartilhando suas realidades sonoras continuamente. Em Destino Pirilampo existem duas formas de produzir resíduo criativo interno e externo ao sistema: 1) através das ações do performer e, 2) dos eventos sonoros fornecidos pelos locais onde a obra ocorre, que constituem um tipo de nicho ecológico.

A ênfase é colocada em agentes onde "o participante atípico (provedor de paisagem sonora) out-group modula os restantes e se torna in group" (FERRAZ; KELLER, 2014: 4). Neste caso, o resíduo criativo dependerá das escolhas atípicas feitas pelos participantes, que tenderão progressivamente à interação, reduzindo a originalidade e aumentando a relevância. Este processo depende da concessão de diretrizes dos participantes com os mecanismos de produção sonora.

Em Destino Pirilampo, não há aumento de entrosamento do sistema, afinal, todos os recursos materiais são sempre renovados e devido à instância de precariedade, não há como diminuir a produção de originalidade. Nesse caso, os eventos de som no ambiente podem servir de base para novos materiais criativos. A combinação de múltiplas paisagens sonoras pode, independentemente das ações dos participantes, gerar propriedades emergentes com características de auto-organização.

7.1.8 Processos, Comportamentos e Cenários: Resenha das Transformações da Performance - PMSE - Dinâmica/Impacto/Estágio inicial-Vínculo

Analiticamente, podemos propor que Destino Pirilampo use as propostas de modelagem em síntese ecológica para simular eventos similares (no entanto, variáveis), aproximando-se do material sintetizado e do material natural. À medida que todo o processamento ocorre em tempo real, as estratégias dos agentes são criadas no momento. Destino Pirilampo permitiu a manipulação de eventos de som de paisagens sonoras distintas e remotas, através da transmissão de dados para um único performer que guia o processo generativo. Em vez de usar sons gravados, Destino Pirilampo usa a transmissão de áudio digital coletada diretamente da geração dinâmica de paisagens sonoras. $O$ intérprete recebe essa mistura contrastante de eventos de som e os manipula através da intervenção de um modelo computacional em Pure Data. Esses modelos usam o conceito de precariedade (IAZZETTA, 2015), ou seja, não propomos um refinamento da captura de gestos, que neste trabalho terá uma função fundamental para o plano de contingência. Através da interatividade, o agente pode se adaptar dinamicamente à estrutura da peça, criando uma experiência auditiva atrativa para o ouvinte, tornando-o um dos agentes criativos desse ambiente. Nesse sentido, ressaltamos que todos os indivíduos envolvidos no ambiente de performance podem, em certo sentido, modificar os padrões finais da comprovisação. Devido à 
volatilidade do ambiente performático, tanto os agentes provenientes das paisagens sonoras enviadas quanto os agentes presentes no local do metasoundcape podem (re)produzir fenômenos capazes de alterar o resultado por completo. Afinal, os recursos materiais consistem principalmente nas inter-relações entre agentes e meios (recursos cognitivos).

\subsection{Estudo de Caso 2: Citações}

Citações , é uma comprovisação para live electronics e voz. A peça é préestruturada para permitir interações múltiplas entre os agentes e/ou as potencialidades dos recursos ambientais em seu entorno. Citações $\sim$ tem como diretriz que inspira sua estruturação, o conceito de retroalimentação (feedback) de múltiplas camadas de som (BHAGWATI apud ALIEL et al., 2015). ${ }^{24}$

Assumimos que uma paisagem sonora pode ser entendida como um sistema de som não-linear (ou dentro dos aspectos desta pesquisa, um sistema socioecológico) que permite interações múltiplas entre os agentes e os recursos materiais e cognitivos envolvidos no meio ambiente. Nossa proposta em Citações $\sim$ consiste em adicionar camadas de recursos materiais: looping instrumental (vocal) e processamento eletrônico, visando o desenvolvimento de um metasoundscape (ALIEL; FORNARI, 2013) através do feedback (DI SCIPIO, 2003). Gravações de performances em vários períodos de tempo são adicionadas em diferentes níveis. Simultaneamente, ocorre o processamento de som que atrasa (delay) a percepção dos sons da fonte sonora acústica da produção eletrônica. Com essa estrutura, buscamos gerar um metasoundscape que tenta afastar-se do senso de reconhecimento auditivo (mascaramento) dos eventos em tempo real dos produzidos no tempo diferido. Existe neste conceito uma liberdade poética para trazer fragmentos de som do passado ao tempo real, criando uma distopia do parâmetro de tempo. As modificações também são consideradas relevantes por outras fontes de som incluídas no sistema.

\subsubsection{Recursos Materiais e Métodos (Plano de Diretrizes)}

Vamos dividir a discussão dos recursos materiais e a estruturação do plano de diretrizes com base em recursos materiais eletrônicos e acústicos.

\subsubsection{Recursos Materiais Eletrônicos}

Citações $\sim$ foi programada no software Pure Data (PD) desenvolvido por Miller Puckette em 1996. PD é uma plataforma de programação visual de código aberto (open source), que permite a criação de algoritmos para: controle, análise, processamento som e síntese de dados multimídia (áudio, vídeo, controle, etc.) em tempo real. 
Para Citações $\sim$ desenvolvemos pelo menos três algoritmos principais que propõem resultados semelhantes, mas usam processamento variado. O primeiro algoritmo foi desenvolvido com dois processadores de delay. Delay é o termo usado no processamento de áudio que indica o atraso de um sinal de áudio, também sinônimo de reverberação ou eco em alguns casos. A principal função desse algoritmo é causar uma variação perceptiva, que pode ser controlada pelo performer, entre a fonte de som acústica e a eletrônica. Por exemplo, quando uma palavra é pronunciada pela voz (canto), ela será percebida em tempo real, no entanto, com o processamento mencionado, a mesma palavra pode retornar no futuro próximo ou distante, à escolha do performer. Os dois processadores de delay permitem ao agente uma série de atrasos entre 0 a $1000 \mathrm{~m} / \mathrm{s}$.

O segundo algoritmo é um gravador de looping, que permite capturar e armazenar sinais externos através do microfone. Através do algoritmo, o agente tem o controle de quando gravar trechos que julga válidos para o desenvolvimento da peça. Foram produzidos quatro gravadores que permitem oito tipos de variações. Quatro que podem ser apagados e reescritos, e quatro que uma vez gravados, permanecerão armazenados ao longo da peça, sem possibilidade de re-gravação (em tempo real). Este sistema dá ao executante um plano de diretrizes, afinal, o material previamente gravado será fixo. A outra ferramenta será mais contingente porque trata da adaptação do agente performático para selecionar conteúdos em tempo real que ele considera relevantes para a peça. Loopings podem ser reproduzidos separadamente ou coletivamente, permitindo múltiplas camadas sonoras.

Além do algoritmo de gravação, um terceiro algoritmo foi adicionado, capaz de controlar os parâmetros temporais do looping. Este algoritmo é estruturado com base no processamento envelope (ADSR). Através de um processo que permite modificar os parâmetros do envelope, é possível selecionar o material relevante do looping. Por exemplo, se uma palavra específica dentro de uma frase for considerada relevante para o agente, ela pode reduzir o envelope para uma condição de redução de ataque, permitindo que apenas a palavra escolhida seja repetida em looping.

Desta forma, o agente pode selecionar uma variação do tempo de reprodução em cada conteúdo gravado. A taxa do envelope pode variar, permitindo ao agente controlar (no aspecto temporal) o sinal que será executado em tempo real. Quanto menor for a taxa selecionada, menor será o tempo de execução e quanto maior for a taxa selecionada, mais tempo será executado. O contexto de utilização de gravações de improvisação como recurso para a produção de material artístico novo é consistente com as propostas de Hannan (2006) e Bhagwati (2014).

Os algoritmos: processadores de delay, gravador e ADSR, levam ao desenvolvimento de ferramentas digitais para comprovisações de camadas sonoras (DUDAS, 2004). Dentro do modelo do sistema socioecológico sugerido por (SIBERTIN-BLANC 
et al., 2011), podemos apontar que existe uma relação com recursos materiais focados na performance. Desta forma, as camadas de interação podem ocorrer entre a voz e os resíduos de som recorrentes de eventos passados que retornam (feedback) via live electronics, modificando as intenções e as adaptações da performance.

Em uma visão artística, esses procedimentos procuram estabelecer uma série de repetições sonoras, curtas e/ou longas em feedback que produzem convergência ou conflitos entre ações acústicas e eletrônicas em tempo real. Essas condições propõem o surgimento de um sistema variante, não linear e cíclico em cada momento. Ou seja, em cada entrada nova pode ser observada uma saída diferente. Essa propriedade alinha-se com a proposta de loop (consulte o Capítulo IV). Embora lidemos com recursos materiais que estão em loop, eles não são totalmente idênticos, permitindo cada nova implantação de contingências que ocorrem na mudança de processo. Esta atividade (SIBERTIN-BLANC et al., 2011) pode ser entendida tanto de forma perceptiva (recurso cognitivo) quanto mensurável (modificação de altura de frequência, ADSR, dinâmica e assim por diante). As interações entre a voz e o live electronics também são drasticamente alteradas devido a repetições, ou seja, "o que à distância pode parecer semelhante, de perto, é sempre diferente". (DI SCIPIO, 2003). Embora parte do processo seja organizada em algoritmos, (planos de diretrizes (composição)), são as contingências emergentes de eventos presentes e passados que propõem significados futuros: uma metáfora para o nome da peça: Citações .

Uma citação é referencial, uma ação que expressa uma ideia ou uma opinião. Neste contexto, em uma perspectiva artística, a performance só existe devido à sua auto-referencialidade. As fontes de som são invariavelmente citadas, criando uma massa de som original, que provavelmente não poderia ter sido alcançada sem uma premissa de feedback. É relevante ressaltar que o conceito de citação no trabalho é subjetivo e não factual. Não há demanda de "citações" no sentido de se referir a algo (social, político, etc.), mas há uma licença poética para eventos não-lineares que se repetem, criando a ilusão de semelhança, mas que de fato estão promovendo condições sem precedentes.

Podemos, portanto, correlacionar Citações com as propostas de Fujak (apud ALIEL, 2015) que rastreiam os padrões do processo de comprovisação com aspectos da vida humana, onde cada escolha pode modificar completamente os resultados. Metaforicamente, seria como um curso que, embora estrategicamente concebido, esteja à mercê de variáveis (com baixo potencial de controle - entidade gelassenheit) que alteram o resultado final. Quanto aos planos de diretrizes para o performer, podemos fazer algumas anotações: 
- O performer de live electronics terá como âncora de interação ${ }^{25}$ (KELLER et al. 2010) o erro do intérprete de voz como condição para fazer as gravações. Existe a possibilidade da intérprete não errar, isso causaria uma ausência de significado das propostas da peça. No entanto, em todas as execuções da peça, essa situação não ocorreu. Aparentemente, a complexidade de ler um texto, o mais rápido possível, torna-se inevitável que ocorram problemas de linguagem. Também deve ser apontado que o erro é considerado nesta estrutura como uma ação consciente, ou seja, quando se propõe realizar Citações $\sim$, o intérprete já possui a prerrogativa de que seu erro é necessário para o desenvolvimento da peça. Portanto, sempre que houver um erro de semântica (procedimento explicado no contexto: voz), o performer irá ativar um gravador de loop, (daqueles que oferecem a opção de gravar, apagar e recarregar). Estes serão os materiais que poderão ser selecionados para a construção de loopings ou manipulados pelo performer através do processamento (delay).

- As opções para usar o processamento ou a reprodução (objetos gravados) serão determinadas por erros na leitura do poema do agente em palavras específicas, tais como: Deus (delay), eternas (looping), entardecer (delay), breves (looping). Os procedimentos possíveis serão mostrados na figura "07". Não há delimitação para o tempo específico pelo qual o artista deve manter um tipo de procedimento, isso dependerá dos erros do intérprete.

- Há momentos mais livres para o agente performático, ou seja, momentos em que ele pode escolher intencionalmente quais procedimentos seguir: processamento ou reprodução. Esses momentos ocorrerão quando o intérprete erra sua leitura nas palavras: sonhar, morrer e dormir. Embora suas ações estejam parcialmente pré-estabelecidas, o agente não sabe completamente quando e como as ações da intérprete vocal ocorrerão resultando em uma situação em que é necessária uma rápida adaptação ao fluxo de eventos. Ou seja, o artista deve se adaptar e responder com pouco tempo de planejamento para as configurações exclusivas. Ao longo do desenvolvimento da performance podem ocorrer momentos de congruência entre a voz e a eletrônica. Se o agente da voz assim desejar, ele pode errar voluntariamente em uma palavra específica, para manter os procedimentos condicionados por ele por um período mais longo na peça. No entanto, isso não parece ser uma opção fácil execução.

25 Âncora de interação - recurso utilizado para demarcar modificações de parâmetros. Uma sinalização para possibilitar a trajetória da performance. Maiores explicações em Keller et al, 2010. 
Figura 7 - Poema e Procedimentos para Live Electronics em Citações

$\begin{array}{ll}\begin{array}{l}\text { Desejo } \\ \text { As coisas que não conseguem morrer }\end{array} & \text { Processamento e Reprodução } \\ \begin{array}{l}\text { Só por isso são chamadas eternas. } \\ \text { As estrelas, dolorosas lanternas }\end{array} & \begin{array}{l}\text { breves: utiliza-se delay } \\ \text { deus: utiliza-se delay. } \\ \text { Que não sabem o que é deixar de ser. }\end{array} \\ \begin{array}{l}\text { Ó força incognas: Utiliza-se delay } \\ \text { O meu querer, como o meu não-querer. }\end{array} & \\ \begin{array}{l}\text { Quisera estar entre as simples luzernas } \\ \text { Que morrem no primeiro entardecer. }\end{array} & \text { Eterna: utiliza-se looping } \\ \text { Ser deus - e não as coisas mais ditosas } & \text { Nebulosas: utiliza-se looping } \\ \text { Quanto mais breves, como são as rosas } & \\ \text { É não sonhar, é nada mais obter. } & \text { Morrer: Improvisar entre looping e delay } \\ \text { Ó alegria dourada de o não ser } & \text { Dormir: Improvisar entre looping e delay } \\ \text { Entre as coisas que são, e as nebulosas, } & \text { Sonhar: Improvisar entre looping e delay } \\ \text { Que não conseguiu dormir nem morrer. } & \end{array}$

Pode-se apontar problemas que devem ser trabalhados em outras comprovisações, tais como: perde a espontaneidade devido à muita atenção necessária para responder os erros do intérprete e a falta de liberdade criativa, afinal, há momentos em que não há erros de semântica sobre as palavras, eles permitem menos liberdade de contingências do performer, limitando suas ações.

\subsubsection{Recursos Materiais Acústicos: Voz}

A priori, a voz foi escolhida porque permitiu o uso do material fonético. Embora as propriedades linguísticas não sejam primordiais na peça, isto é, não se prioriza que o texto seja entendido em português. É intencional causar a sensação de que algo pode ser entendido. Escolhemos um poema de Cassiano Ricardo chamado Desejo. A escolha foi puramente casual, e qualquer outro texto, poético ou narrativo, é adequado. Alguns procedimentos foram projetados dentro de um plano de diretrizes para manter 0 sistema coeso (no nível de composição). O intérprete deve começar a ler o poema o mais rápido possível, e com cada erro linguístico (por exemplo, o intérprete não pode pronunciar uma palavra corretamente), ela deve recomeçar a ler o poema no tempo inicial. No entanto, existem outros procedimentos (citados abaixo) que utilizam erros linguísticos para desenvolver novas possibilidades. 
Algumas palavras foram selecionadas dentro do poema. Em caso de erro de pronúncia, podem ocorrer mudanças de dinâmica, progresso ou direção. Podemos citar alguns exemplos: errando a pronúncia, conscientemente ou inconscientemente, da palavra "morte", a peça termina. Estes procedimentos foram desenvolvidos sob um conceito de comprovisação denominado fluxograma de opções (BHAGWATI apud ALIEL et al., 2015), visualizado no capítulo II.

Foram selecionadas algumas palavras que permitiram que o intérprete escoIhesse. Por exemplo, no caso de um erro linguístico sobre a palavra "nebulosas", o agente pode optar por começar a ler novamente conforme estabelecido a priori ou começar no final do poema. Semelhante a este processo, a palavra "deus" permitiu a escolha de uma leitura não convencional (da direita para a esquerda), em que se proponha novos paradigmas de erros e, portanto, novos planos de contingência.

Figura 8 - Procedimentos para a voz em Citações $\sim$

\begin{tabular}{|c|c|}
\hline Cassiano Ricardo & Laranja: Finaliza-se a comprovisação \\
\hline As coisas que não conseguem morrer & Verde: a leitura torna-se dinamicamente piano ou pianíssimo; \\
\hline por isso são chamadas eternas. & Marron: a leitura torna-se dinamicamente Forte ou Fortíssima; \\
\hline & Bege: duas opções: ler alternadamente as linhas (pulando \\
\hline S estrelas, dolorosas lanternas & $\begin{array}{l}\text { linhas), ler alternando os andamentos (hora rápido, hora } \\
\text { lento); }\end{array}$ \\
\hline ue não sabem o que é deixar de ser. & Azul: duas opções: leitura no método Ocidental convencional \\
\hline Ó força incognoscível que governas & $\begin{array}{l}\text { (esquerda para direita de cima para baixo), leitura inversa (de } \\
\text { baixo para cima, espelhamento de palavras); }\end{array}$ \\
\hline O meu querer, como o meu não-querer. & Amarelo: A leitura se tornará mais lenta possivel; \\
\hline Quisera estar entre as simples luzernas & $\begin{array}{l}\text { Roxo: suspiros, respirações e afins devem ser adicionados à } \\
\text { leitura; }\end{array}$ \\
\hline $\begin{array}{l}\text { Que morrem no primeiro entardecer. } \\
\text { Serdeus_-e não as coisas mais ditosas }\end{array}$ & $\begin{array}{l}\text { Rosa: Duas opçôes: Reler o texto em frequências agudas, Reler } \\
\text { o texto em frequências graves; }\end{array}$ \\
\hline Quanto mais breves, como são as rosas & \\
\hline É não sonhar, é nada mais obter. & \\
\hline Ó alegria dourada de o não ser & \\
\hline Entre as coisas que são, e as nebulosas, & \\
\hline e não conseguiu dormir nem morrer. & \\
\hline
\end{tabular}

Embora o poema se torne um processo fechado (plano de diretriz), não permitindo, pelo menos no contexto deste trabalho, variações em seu conteúdo, o erro linguístico se torna o material pelo qual o artista expõe contingências. $O$ intérprete pode errar de forma intencional e involuntária, possibilitando resultados mais ou menos controlados. Por exemplo, é possível que o intérprete termine a comprovisação, interpretando intencionalmente a palavra "morrer", ou a peça pode terminar sem uma prerrogativa voluntária se ela errou na palavra citada. 
Semelhante ao plano de contingência do live electronics, o agente do poema terá que desenvolver adaptações metodológicas durante a performance, com pouco tempo de preparação. Mesmo que existam métodos específicos sobre como proceder (parte compositiva), o que determina se os métodos serão ou não utilizados serão ações inesperadas ou simplesmente o erro (gelassenheit). Ao adicionar o erro intencional como processual, temos o propósito de controle, que abre a prerrogativa para o agente manipular todo o processo criativo. Mas o erro simulado tende a ser uma rota atrativa pela qual a comprovisação ocorre. Todo o resultado pode ser alterado sem tempo de planejamento. É necessário, portanto, que o agente se adapte ao novo material para que a comprovisação continue. É válido apontar que cada modificação da voz resultante terá influência nas ações do performer e vice-versa resultando em interações diferentes ou paralelas, trazendo significado ou não para as questões criativas da peça.

\subsubsection{Recursos Cognitivos}

Como mencionado por Sibertin-Blanc et al., (2011), os recursos cognitivos são fortemente variáveis e não podem ser mensurados devido à sua volatilidade. De acordo com o mesmo modelo, o autor sugere apontar fatores significativos que podem fornecer condições relevantes ao sistema em vez de cumprir todas as condições.

Semelhante ao Destino Pirilampo, Citações $\sim$ fornece recursos de opções criativas:

1) O agente performático pode simular o erro, esta ação implica na produção de material original para todos os envolvidos, alterando metasoundscape.

2) Em momentos de maior liberdade improvisada, o agente pode mudar os processos tecnológicos para modificar drasticamente o ambiente sonoro.

\subsubsection{Plano de Contingência e Modelagem Socioecológica}

\subsubsection{Instâncias (similaridades) e Observação de Interação entre Agentes}

Citações $\sim$ ao tentar desenvolver um metasoundscape através do feedback de camadas de som, propõe problematizações a serem exploradas pela área da comprovisação. De questões práticas, como o uso de erros intencionais e involuntários no processo criativo, as adaptações ativas nas ações dos performances necessárias para contingências e interações não-lineares entre agentes, produzindo ambientes tão díspares. 
7.2.5.2 Processos, Comportamentos e Cenários: Resenha das Transformações da Performance - PL - Dinâmica/Impacto/Estágio inicial-Vínculo

Os conceitos citados neste tópico tiveram a função de teorizar o desenvolvimento das Citações $\sim$ e tornarem-se relevantes quando tratados nos moldes que foram concebidos (modelagem de sistemas socioecológicos).

Citações $\sim$ emprega o uso de recursos materiais que serão gerados a partir de um episódio (leitura de poemas) que se desenvolve em vários níveis de camadas sonoras com o objetivo de levar a um metasoundscape. $O$ episódio referente, portanto, determina a principal fonte de recursos cognitivos disponíveis nesse ambiente, na acomodação de recursos materiais. À medida que as camadas sonoras são adicionadas de forma contínua e em feedback, com cada nova camada, todos os eventos sonoros, sejam eles provenientes do episódio ou não (sons ambientais, públicos e similares) tornam-se parte integrante da comprovisação. A proposta em looping fornece recursos materiais para Citações sendo possível devido ao uso de recursos tecnológicos.

Sob condições convencionais, PLs têm baixas conjecturas originais. Como o mesmo material é retroalimentado várias vezes, existem desentendimentos, mas estes são sutis e não originais. Em Citações observamos a modificação desta característica, afinal, o erro é considerado como um estado para criar as ações que serão retornadas. Ou seja, um erro acidental e a escolha de um erro simulado (ver materiais e métodos) tem o papel de gerar material original, que pode ou não ser relevante. O material de erro acidental cria uma circunstância inesperada, modificando o processo linear existente de propostas de loop. Parte desse material original tende a ser residual criativo, afinal, como a maioria é causada por erros acidentais, eles podem não ser pregnantes o suficiente para serem desenvolvidos por todos os agentes.

É necessário apontar os problemas que podem ser visualizados em Citações $\sim$, que podem prejudicar o desenvolvimento de comprovisações, tais como:

1) Dificuldade em manter ações múltiplas, ou seja, seguir etapas complexas que às vezes conflitam com ações contingentes,

2) Impedimento de expressão artística causada pela complexidade das ações. As interações altamente díspares são recorrentes, reduzindo as condições de criatividade, prejudicando a fluência da peça. Embora os problemas observados tenham sido suavizados devido a vários ensaios, eles trazem questões que podem ajudar a tornar a comprovisação mais adequada à expressividade artística. 


\subsubsection{Entidade de Interface: (MDF) Impactos de Fontes Externas e Internas}

Sobre as relações entre agentes quantitativamente, encontramos em Citações dois agentes que realizam forças internas, que trocam interações consensuais em uma escala maior ou menor. Essa mudança fornece a maior relevância do material para que as interações tenham maior consenso. O erro acidental pode ser interpretado como uma força externa (gelassenheit) que não possui interação consensual e produz material original. Ou seja, a interação entre agentes gradualmente cria seletividade de uso do material, mas o erro se torna a condição que remove o emaranhamento do agente. Outros agentes contidos no ambiente podem ser considerados, o que pode contribuir para a modificação do padrão final da peça. No entanto, esses agentes, apesar de possuir atributos capazes de produzir material original, provavelmente produzirão grandes quantidades de material residual criativo.

\subsection{Estudo de Caso 3: "Lyapunov Time"}

Lyapunov Time (LYT) é uma comprovisação para quatro clarinetes e live electronics realizado no II Painel de Som - Criação e Interpretação de Música Contemporânea que ocorreu em 05 de dezembro de 2016 no Departamento de Música da Escola de Comunicação e Artes (ECA) da USP.26

A peça propõe uma interlocução entre instrumentos acústicos e estrutura de som digital visando um ambiente multimodal usando uma metáfora para a teoria de Aleksandr Mikhailovich Lyapunov. Lyapunov era um renomado matemático russo que trabalhava na área de desenvolvimento da teoria da estabilidade de sistemas dinâmicos, bem como por suas diversas contribuições à física, à matemática e à teoria da probabilidade.

Como inspiração, utilizamos seu trabalho na área da matemática teórica sobre o período (tempo) em que um sistema dinâmico se move de uma condição de ordem para um estágio caótico. De acordo com a teoria de Lyapunov, todo sistema dinâmico tem um período de tempo regular que em um momento mensurável torna-se caótico. Em matemática, o sistema dinâmico é o sistema que possui uma regra definida descrita no espaço geométrico. Em outras palavras, um modelo geral para sistemas que evoluem de acordo com as regras, em vários estados temporais.

O "tempo" de Lyapunov é usado em várias medidas de sistemas dinâmicos, mas é amplamente citada ao lidar com medidas imensas, por exemplo, o sistema solar. Obviamente, a definição usada aqui não aborda toda a complexidade das discussões sobre o assunto. Nosso núcleo não confronta nenhum objetivo definido ou topologia, nosso foco é a metáfora de sistemas dinâmicos e como eles se tornam caóticos,

26 A performance pode ser visualizada em: https://www.youtube.com/watch?v=gCXa4r1Q1yQ 
conforme proposto por Lyapunov. Vamos abordar a questão diante de um plano estético, um conceito matemático inspirando uma premissa artística.

Assumindo a conceituação de sistemas dinâmicos a partir da perspectiva da matemática, tentamos explorar a mesma concepção em uma inspiração artística. Compreendemos a apresentação como um sistema dinâmico que possui regras e eventos contingentes. Portanto, define-se um plano de diretrizes que inclui as ações recorrentes e a construção de ferramentas para a execução do trabalho. Usamos um plano de contingência que fornece variações de material e a adição de eventos imprevisíveis em um período mensurável resultante da fragmentação da ordem de som do sistema. Em outra perspectiva, os planos de diretrizes representam as regras estabelecidas (composição) que irão reger o sistema dinâmico (performance) e o plano de contingência (improvisações) serão as ações intencionais e imprevisíveis recorrentes no sistema, capazes de transfundir o mesmo em um caótico resultante

\subsubsection{Recursos Materiais e Métodos (Plano de Diretrizes)}

Vamos dividir a descrição de métodos e materiais em dois planos, a construção das ferramentas comprovisacionais para instrumentos acústicos e eletrônicos.

\subsubsection{Recursos Materiais Acústicos}

Para a construção do conteúdo acústico, concebemos uma representação de um sistema dinâmico que evolui para um sistema caótico. Desta forma, escolhemos como "narrativa" os eventos observados em um pêndulo composto.

Figura 9 - Pêndulo Composto em Estado Regular

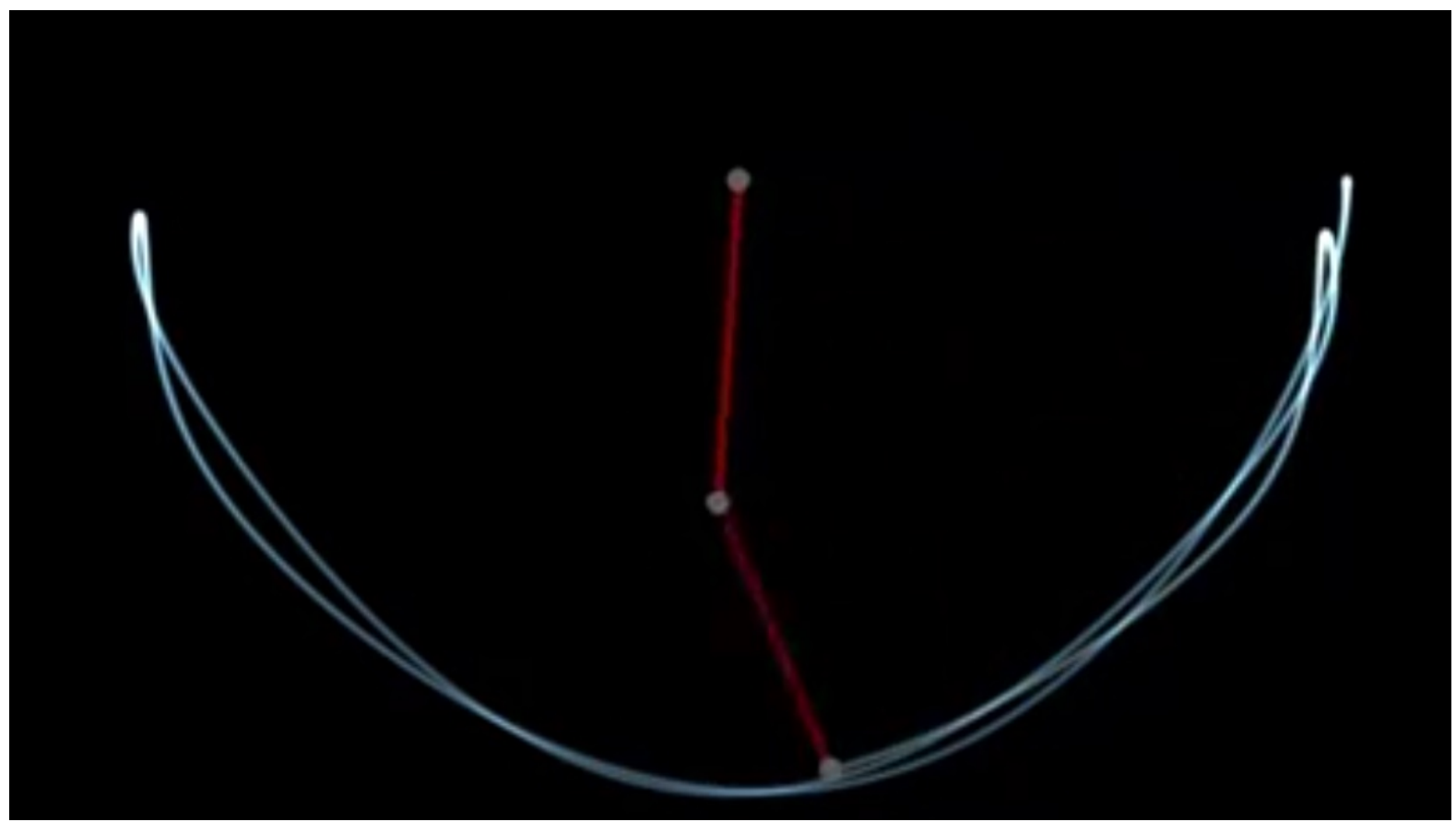


Ao usar um pêndulo composto (um pêndulo que tem um eixo em sua metade) é criado um experimento da matemática aplicada. Liberando a energia potencial existente no pêndulo, isso inicia um movimento de arco regular. Em certo momento, o movimento regular deixa de existir, gerando movimentos irregulares, que assumimos como caóticos, ou pelo menos imprevisíveis. Uma vez que os movimentos se tornam irregulares, eles não retornam a um padrão regular e mensurável, tornando-se completamente caótico. O período (tempo) entre movimentos organizados e movimentos irregulares é definido como o "tempo de Lyapunov".

Figura 10 - Pêndulo Composto em Estado Irregular.

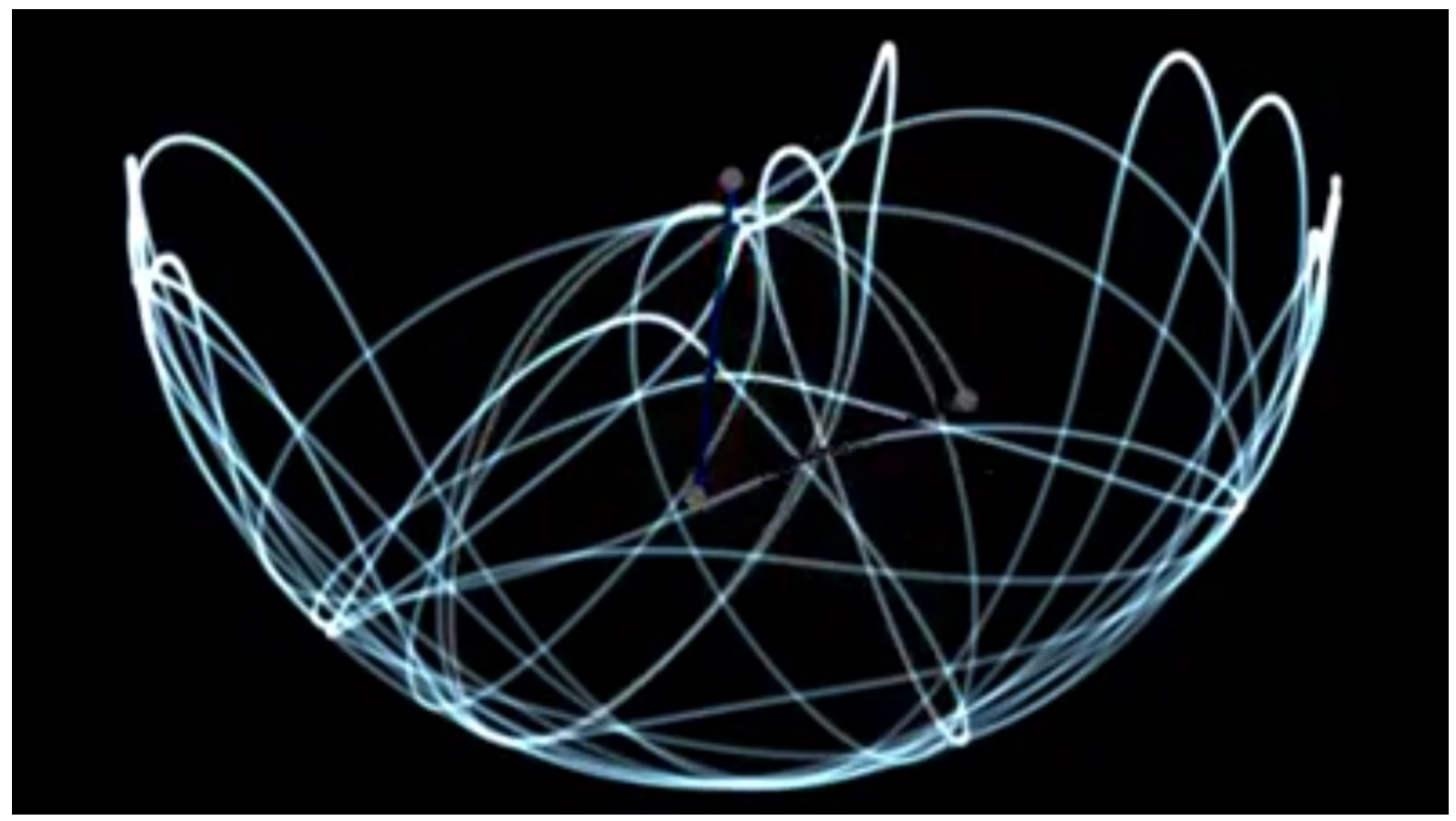

Este experimento foi a base para o desenvolvimento dos planos de diretrizes da LYT. Utilizamos o conceito/imagens dos movimentos do pêndulo como resultado da determinação das alturas de som transcritas para a partitura. Por exemplo, ao iniciar os movimentos, o pêndulo adquire um design linear e regulado, com base nesse resultado, escolhemos a base do movimento (a parte "inferior" do movimento do pêndulo) como ponto de partida da execução da peça.

Nesta abordagem, podemos citar o trabalho do Backhouse (2011) que incorpora o uso de ferramentas de design visual para manipular fotografias ou modelos tridimensionais de objetos materiais. Os gráficos disponíveis neste tipo de material podem ser usados para representar e determinar parâmetros musicais. Na obra Chi-Ca-Go (BACKHOUSE, 2011), para voz e trilha eletroacústica, Backhouse usa figuras de um grupo de edifícios da cidade de Chicago como matéria-prima para o trabalho de composição. Essas figuras são fragmentadas em elementos gráficos como apontam Mello; Keller (2013). 
Para abordar a metodologia da marcação de processual gráfica (MELLO; KELLER, 2013. Apresentada no Capítulo VI) desenvolvemos uma estrutura gráfica que indica procedimentos a serem realizados por meio de indicativos ou marcas. Em LYT, as "memórias" gráficas do movimento pendular nos propõem uma organização linear dos eventos, permitindo singularidades em variações sonoras. Com essas "lembranças" visuais, adicionamos pequenos procedimentos técnicos ou variações de timbre, limitando a abordagem de agentes performativos, mas permitindo a intencionalidade.

Para manter um fluxo contínuo de cada página do LYT, usamos o recurso de vídeo como método. As páginas da partitura de LYT produziram um vídeo. Cada página muda automaticamente quando o tempo escolhido termina. O vídeo, portanto, quando iniciado, gera uma narrativa linear de eventos (mudanças de página) sem a necessidade de os agentes se preocuparem com esse fator.

É relevante ressaltar que alguns agentes se sentiram desconfortáveis com essa proposta, escolhendo usar páginas em papel. Não recebemos nenhum argumento específico para essa escolha, limitando-se a afirmar que eles "preferiram". Aceitamos a escolha dos agentes. Devido a esta escolha, a performance não ocorreu de forma imaginada, permitindo encontros e desajustes entre aqueles que usaram o vídeo e os papéis. Consideramos isso uma escolha intencional que afeta diretamente as contingências na LYT, afinal, produziu conteúdo previamente imprevisível e variante.

Vamos demonstrar as páginas LYT e o tempo específico de cada uma delas no vídeo. A primeira página tem uma periodicidade de 0 "até 0:50":

Figura 11 - Página I de LYT

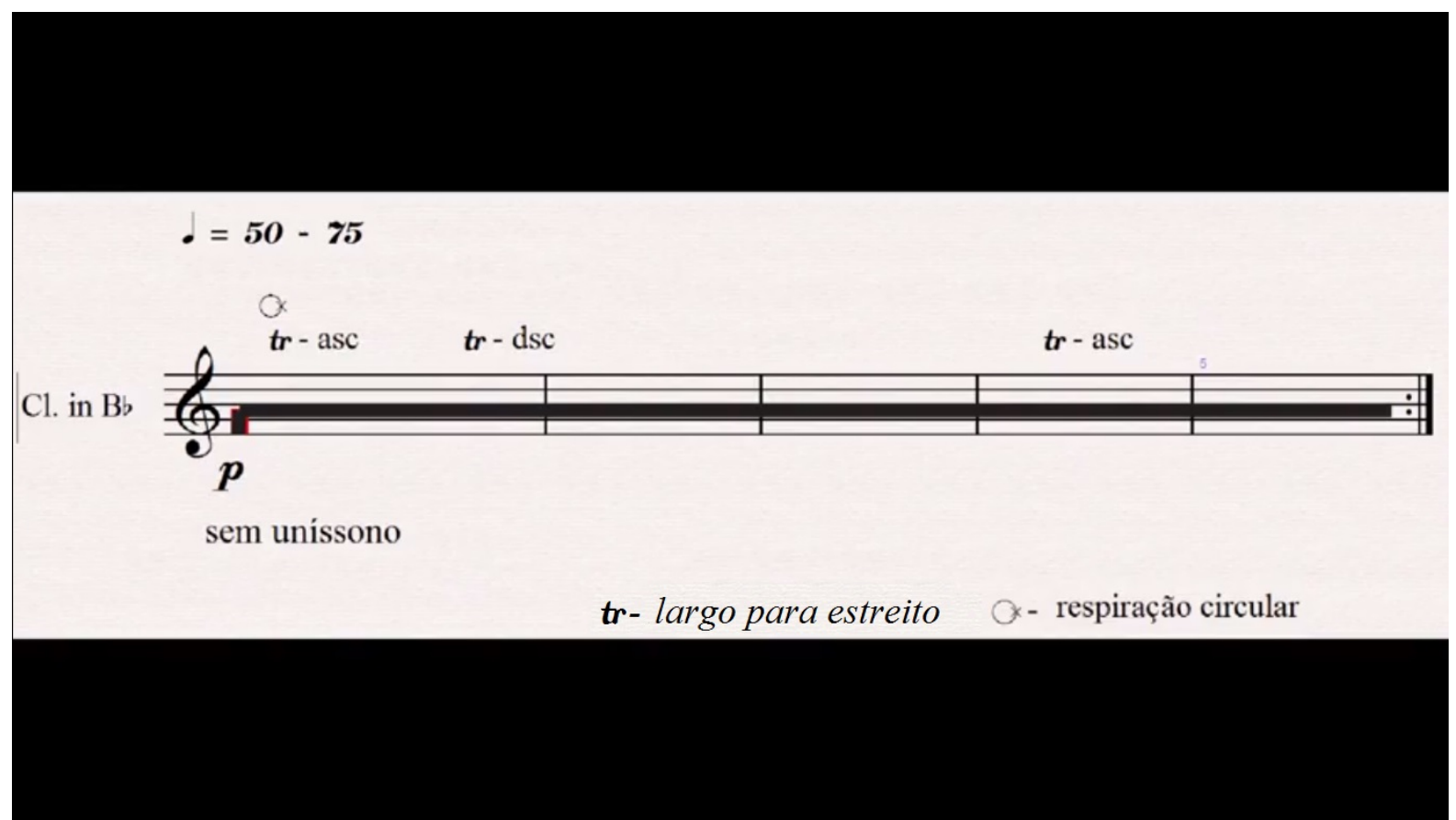


Na página I de LYT, observamos que os quatro clarinetes devem começar sua execução de uma maneira aproximada ao Lá3 da clave do Sol, no entanto, é pedido para evitar o uníssono em uma relação metafórica com os movimentos iniciais do pêndulo que parecem iguais, mas que têm variações. Usamos técnicas como trinados para enfatizar essas pequenas variações de freqüências. Como mencionado, os quatro instrumentos começam juntos, mas cada instrumentista propõe seu progresso, que deve variar entre 50 e 75 bpms. Ao chegar ao ritornello, cada agente performático (instrumentista) tem a opção de mudar seu andamento ou manter sua escolha inicial.

No segundo conjunto de procedimentos, apontamos para considerações sobre o uso de instrumentos de timbre semelhantes porque criam várias representações sonoras (vários períodos de som, mas com uma representação similar), ou seja, embora existam sugestões de que os instrumentos devem produzir frases semelhantes, o seu conteúdo é sempre variável. Nós escolhemos, portanto, quatro clarinetes por causa de sua variedade de técnicas estendidas e similaridade de timbre.

Especificamente, na escolha de técnicas estendidas em LYT, indicamos a possibilidade de uma microestrutura em relação à comprovisação. Ou seja, em um acompanhamento macro, como tratado neste trabalho, a comprovisação seria uma vertente artística que usaria planos de diretrizes (composição) com abordagens de contingência (improvisação). As técnicas estendidas instrumentais são uma prática comum entre compositores do século XX, como lannis Xenakis, Luciano Berio, Helmut Lachenmann, entre outros. Nossa abordagem é consistente com a conceituação da técnica estendida como um recurso comprovisador, isto é, a construção microestrutural da comprovisação. Neste segmento, a técnica estendida aborda um plano de diretrizes claro, no entanto, isso é inclinado a permitir a liberdade intencional dos agentes determinar abordagens contingentes.

As abordagens de contingência dentro de uma comprovisação seriam aspectos restritos que permitem a possibilidade de variação com base na intencionalidade. Analisando o exemplo citado da página I sobre trinados, observamos uma técnica específica, de relativa facilidade para clarinetistas, mas que propõe uma diversidade de variações (neste segmento: contingência) que provavelmente terá uma baixa taxa de repetição semelhante e improvável igualdade sonora. Ou seja, mesmo que haja intencionalidade da repetição exata, a sua criação torna-se duvidosa. Antes da condição de repetição perfeita, o trinado ainda possibilita variações intencionais, como velocidade, altura, timbre e etc.

Acreditamos que, para uma abordagem comprovisacional, a inclusão de técnicas estendidas ou técnicas ampliadas que permitam contingências seria fundamental. Em um exemplo de LYT na página II, encontramos a descrição da técnica: velouté - pouco frulato. Em uma interpretação comprovisacional, observamos este procedimento como 
uma diretriz, ou seja, informações que podem ser reproduzidas por qualquer agente que domine a técnica. No entanto, cada performance terá variações de som causadas por essas técnicas, permitindo condições que podem ser concebidas, mas não previstas (gelassenheit).

Podemos sugerir quais os resultados dos procedimentos, (como o velouté ou 0 frulato respondem), mas não exatamente como em cada performance eles se comportam. Essas contingências podem causar ações e reações inesperadas, permitindo um ambiente de som volátil e imprevisível, semelhante ao encontrado na natureza.

Figura 12 - Página II de LYT

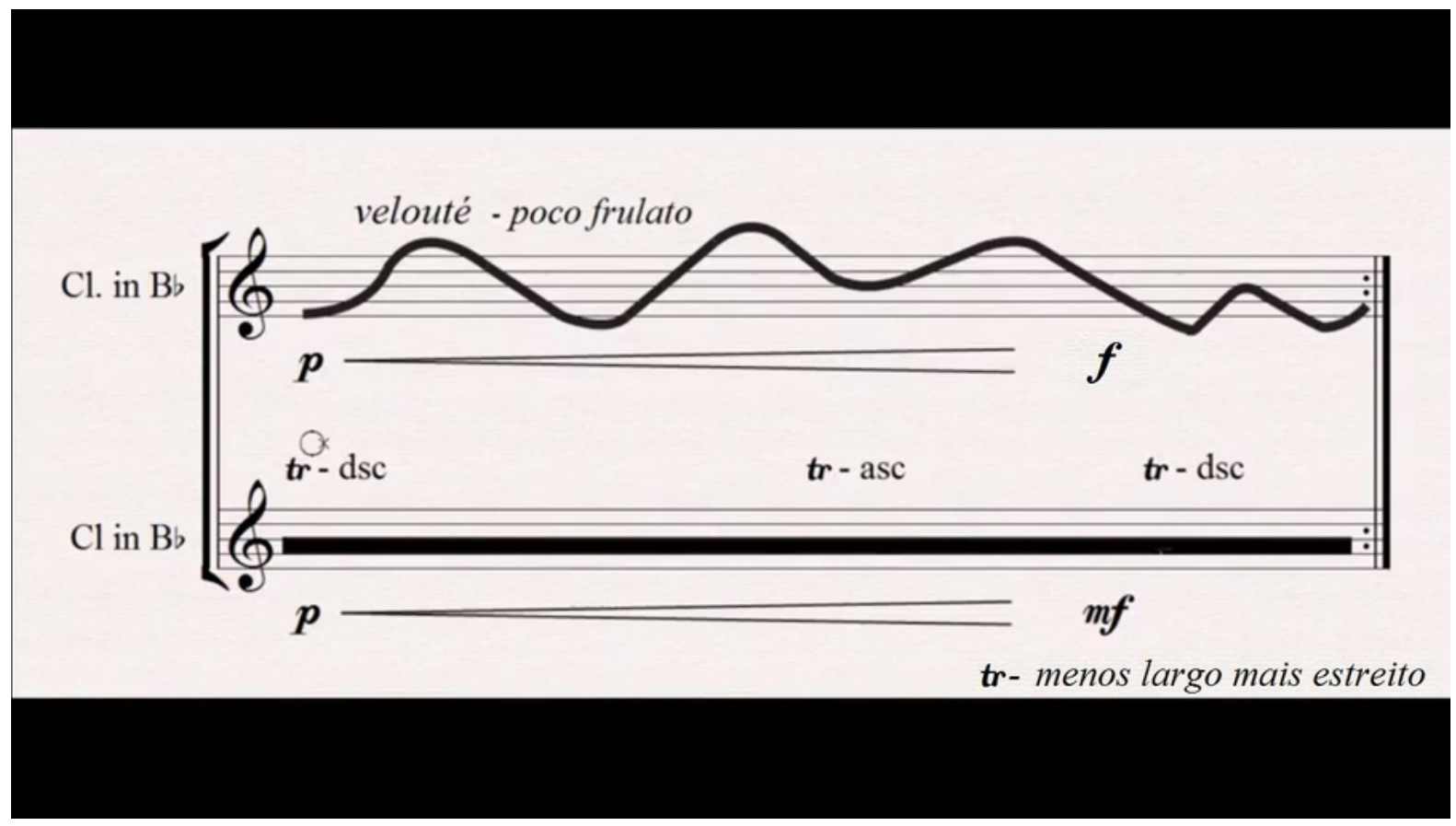

A segunda página tem uma periodicidade de 0:50 "para 1:46“. Nesta página, você encontrará novas informações sobre os procedimentos. Nós usamos o mesmo método de escolher os movimentos do pêndulo, no entanto, nesta segunda página, usamos as bordas dos movimentos do pêndulo para gerar uma "voz adicional" na partitura.

Semelhante ao que acontece na página 1, os agentes performáticos têm a liberdade de escolher a voz a seguir. Eles podem permanecer na região perto do Lá3 ou variar suas alturas simulando as grafias propostas. $\mathrm{O}$ andamento deve permanecer próximo de 50 a 75 bpms. Quando chega ao ritornello, os agentes performáticos podem migrar de voz sem uma diretiva determinante, permitindo o processo de escolha da abordagem. A peça foi originalmente pensada para quatro instrumentos, nesta conjuntura, as principais contingências ocorrem em relação às escolhas em tempo real dos agentes performáticos. Não há como prever quantos instrumentos serão em cada 
voz, e quais mudarão suas vozes em cada repetição (looping), levando a mudanças integrais ou insuficientes. Mesmo que haja pouca mudança, não será possível prever quando isso ocorrerá.

Na página três, expandimos a comprovisação para três vozes, seguindo a mesma dinâmica das páginas anteriores. Os agentes agora podem escolher qualquer uma das três vozes e, quando chegam ao final do ritornello, podem migrar para qualquer voz. Semelhante à segunda página, as escolhas levam a modificações singulares, que podem ser imaginadas, mas não podem ser previstas.

Figura 13 - Página III de LYT

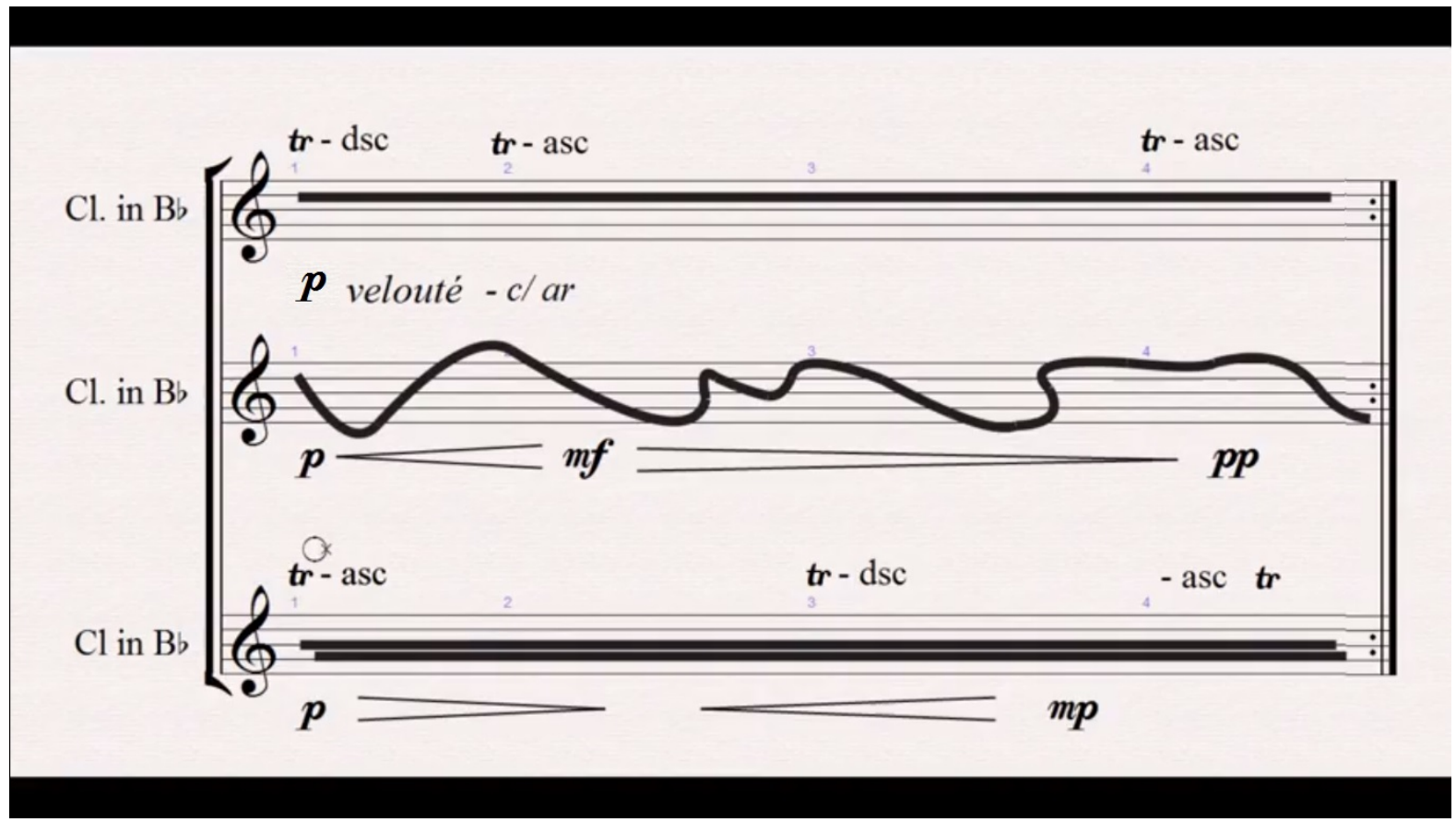

Na página quatro, seguimos as mesmas decisões dos planos de diretrizes que vimos anteriormente. Neste ponto, as quatro vozes estão em condições separadas. Metaforicamente, esse seria o ponto de partida onde o estado de "caos" começa, (o tempo de Lyapunov). 
Figura 14 - Página IV de LYT

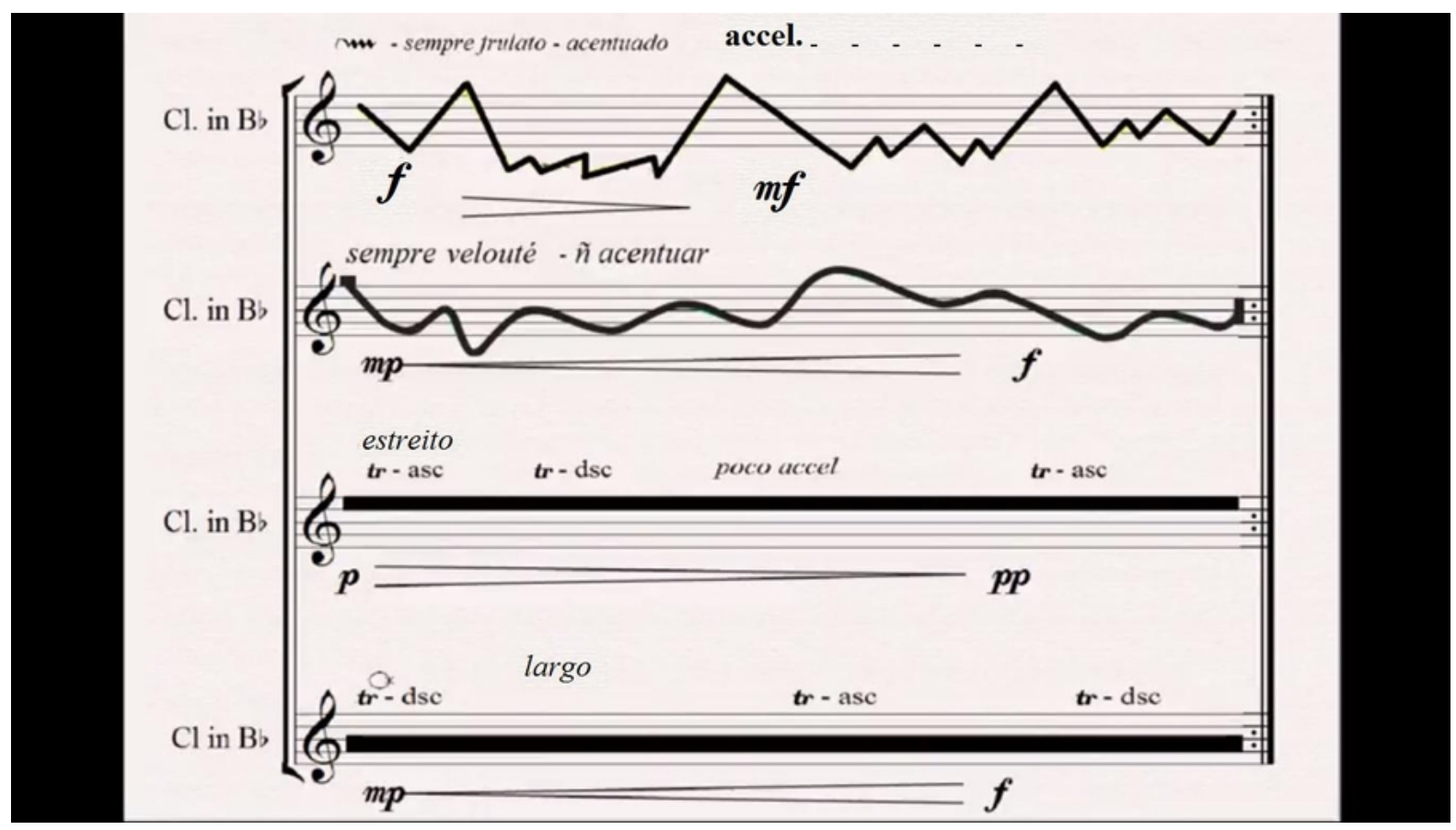

Na página cinco, as diretrizes permanecem, com novas inclusões de técnicas estendidas. Da página cinco, consideramos que vários materiais se decompõem em diferentes níveis. Há também a premissa da marcação processual gráfica inspirada no pêndulo, no entanto, consideramos pequenas inclusões de materiais remanescentes na experiência do pêndulo que podem ser associadas a grafias tradicionalmente ligadas à música de concertos. Como exemplo, destacamos as notações rítmicas tradicionais para as técnicas-chave do clarinete. Essa inspiração foi retirada dos "acentos" visuais causados pela curvatura do pêndulo.

Também foram incluídos pequenos materiais inconsistentes com o conceito inicial que faz referência ao conceito de entidade Gelassenheit (explicado mais detalhadamente no capítulo VI deste trabalho). Em LYT, esta abordagem propõe aos agentes um "mistério" (HEIDEGGER, 1967) a ser descoberto durante a execução da peça. Em termos técnicos, esses pequenos "enxertos" não estão constantemente no vídeo. Há momentos em que este tipo de conteúdo aparece e logo desaparece. Podemos apontar modificações nas anotações de dinâmica, tempo e até pequenas variações de alturas. Os agentes não têm pleno conhecimento de quando esses conteúdos técnicos existirão, projetando um estado de atenção causado pela ausência de previsibilidade. 
Figura 15 - Página V de LYT

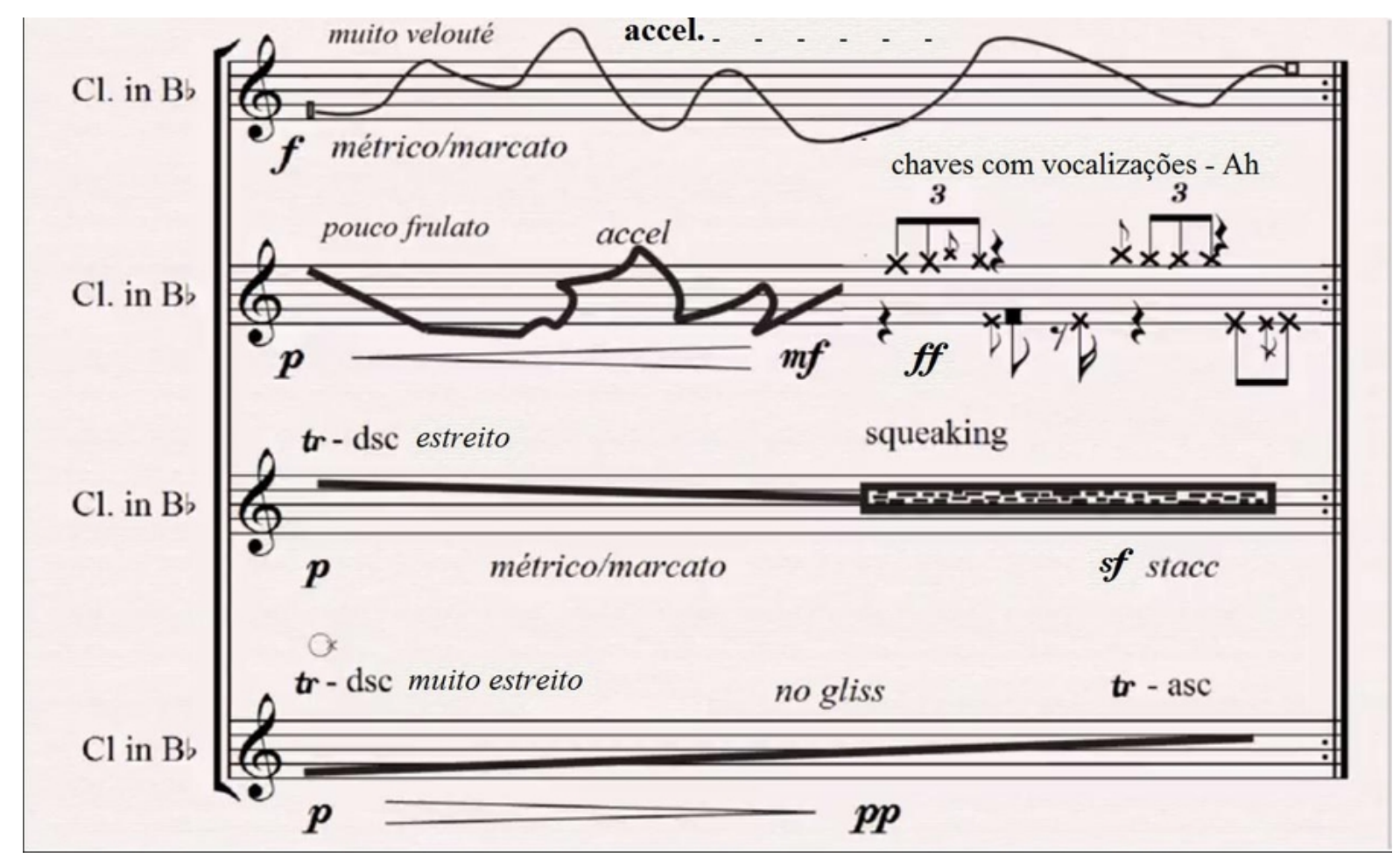

Com o início da página seis, os planos de diretrizes permanecem, no entanto, temos uma mudança dos movimentos e do comportamento dos instrumentos. As opções de mudança de voz permanecem como os pequenos enxertos Gelassenheit. Metaforicamente, buscamos um estágio em que o caos transmutou completamente $o$ material inicial para um novo estágio, criando um ambiente mais esparso e rarefeito. As técnicas estendidas como sons multifônicos e vocalizados dentro do instrumento buscam instabilidade no controle de som, ou seja, a tentativa de trazer contingências imprevisíveis para a comprovisação. Neste mesmo segmento, movimentos aleatórios nas chaves são regras que estabelecem esse mesmo parâmetro. 
Figura 16 - Página VI de LYT

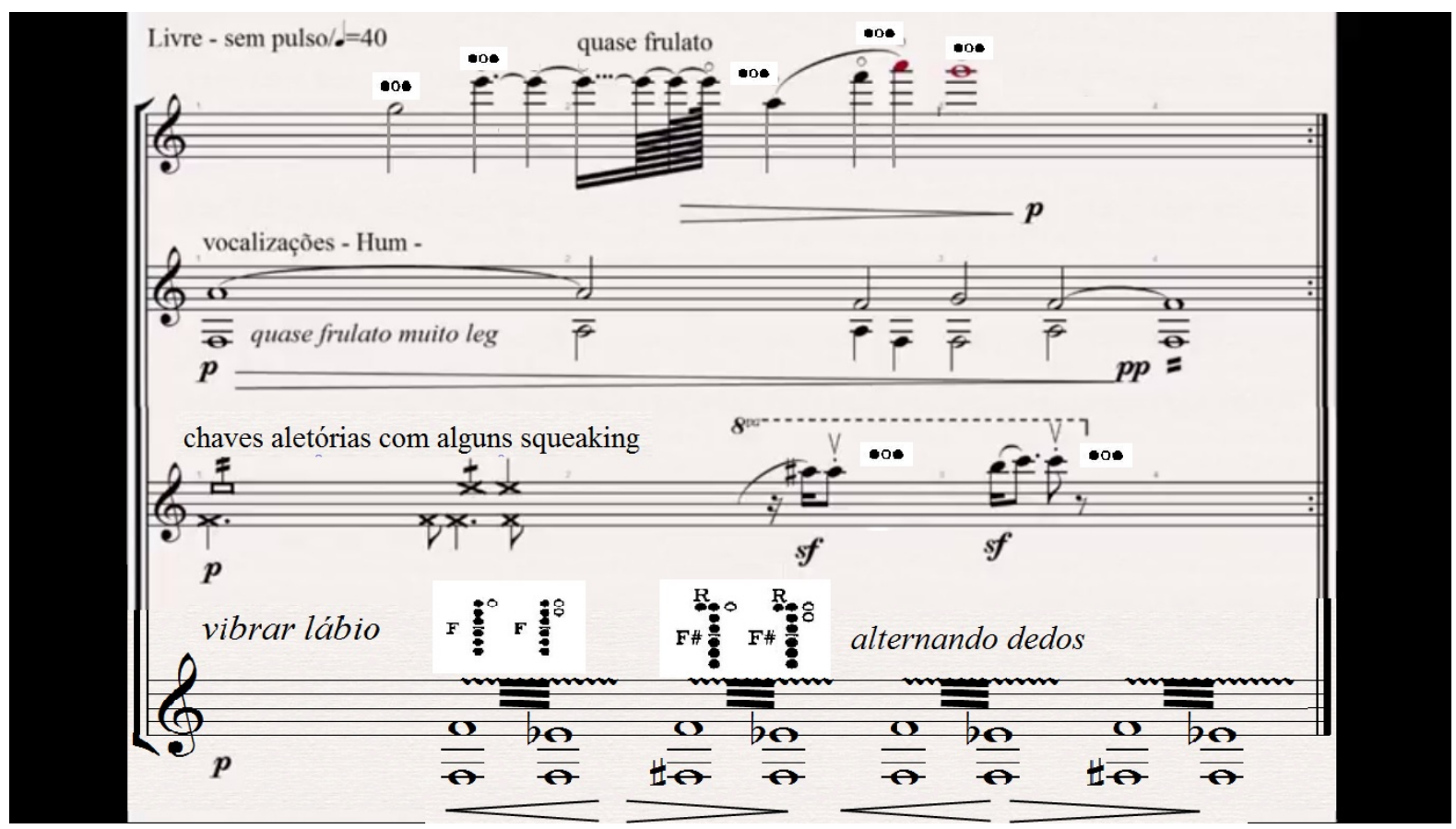

Na página sete, a premissa do conteúdo rarefeito continua a migrar entre sons multifônicos e vocalizados. Neste ambiente, o plano de diretriz visa não refletir mais o movimento do pêndulo, mas sim as "lembranças" dos gestos produzidos pelos agentes no processo inicial da peça, modificando drasticamente o material introdutório.

Figura 17 - Página VII de LYT
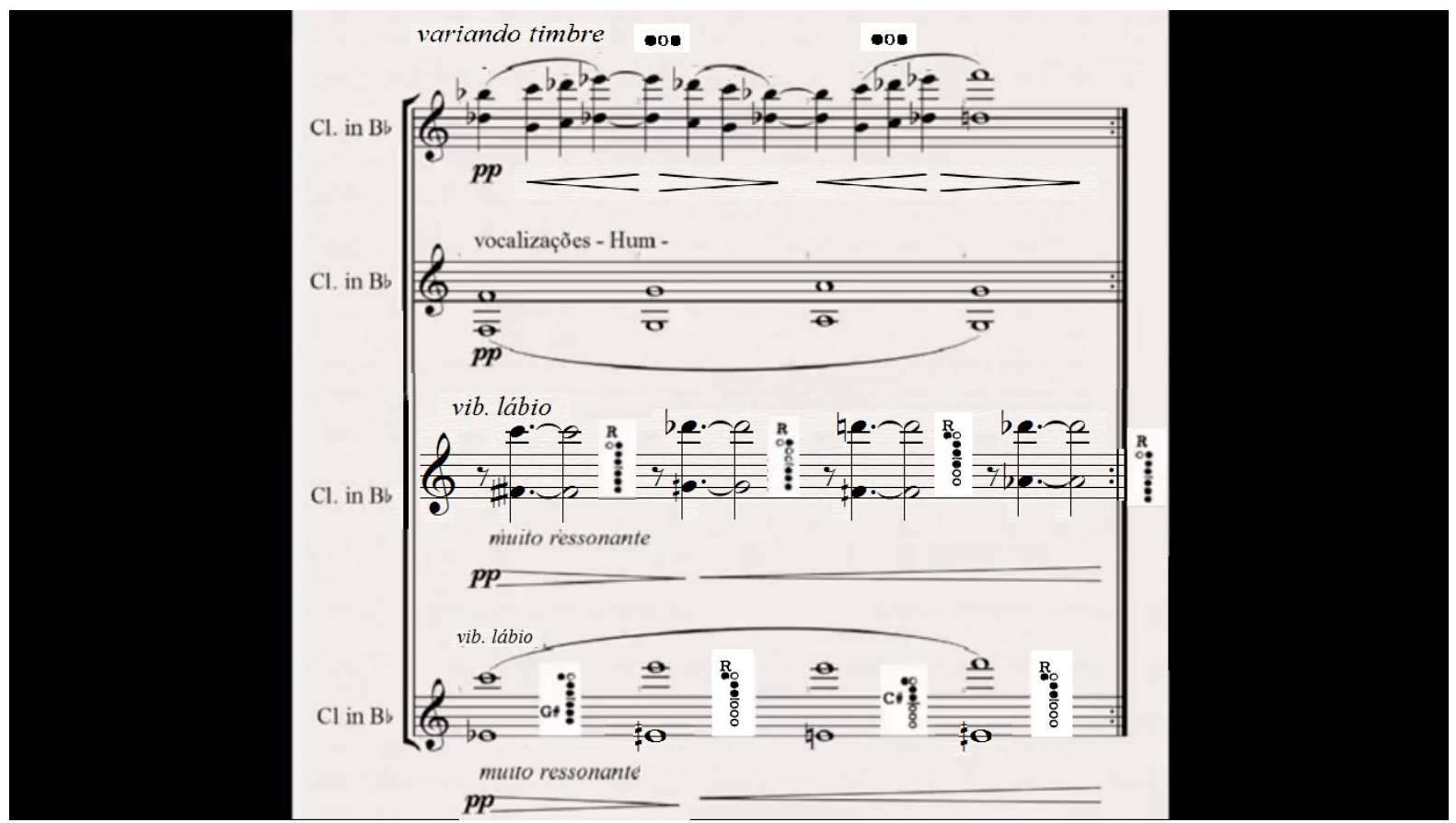

Finalmente, na página oito, contemplamos uma finalização para LYT em uma 
representação final das "memórias" dos gestos pendulares que diluíram no tempo simbolizando o desperdício do material primordial que se tornou caos e migrou para algo aprazível.

\subsubsection{Recursos Materiais Eletrônicos}

Na construção eletrônica, o software Pure Data foi usado para criar um ambiente de vídeo e áudio multimodal. Nosso objetivo é que as ferramentas eletrônicas trabalhem parte em conjunção parte em contraponto para os processos acústicos. Metaforicamente, a proposta estabelece padrões para uma organização de som que se dissipa em direção ao caos. Usamos recursos de processamento eletrônico para melhorar as propriedades caóticas de som e imagem. Através de recursos como mudanças de freqüência na parte sonora ou blur na parte visual, é desejada uma maior desordem dos sentidos visual e auditivo. Vamos dividir a nossa descrição em duas vertentes: áudio e vídeo.

\subsubsection{Processamento de Áudio e Recursos Comprovisatórios.}

Neste tópico, descreveremos o processamento de som usado no LYT. Foram utilizados seis tipos de processamento de som e um player de amostragem (samples). Todo o processamento pode ser alterado em tempo real, permitindo ao intérprete a liberdade de improvisação e manipulação. Os processamentos são pitch shifter, envelopamento sonoro, delay, reverb, filtros de passa-baixa e espaçamento sonoro.

O uso desses processamentos segue uma ordem processual que permite múltiplas variações sonoras de forma empírica. Organizamos um mecanismo de disparo de som de quatro amostras. Essas amostras são o resultado de gravações de improvisações e/ou ensaios de LYT, partindo para a expansão no trabalho de Hannan, (2006). Esta abordagem será desenvolvida no próximo tópico. Os disparos são organizados por um algoritmo estocástico (gelassenheit) que seleciona qual sampler será executado. Este procedimento permite a imprevisibilidade das ações realizadas (no caso de amostras). A partir do disparo, o conteúdo pode ser manipulado com apenas um ou vários tipos de processamento. Descreveremos algumas peculiaridades e funções dos processos:

Pitch Shifter: Este processamento permite a troca de frequências. Em LYT, o pitch shifter tem a função de modificar os parâmetros sonoros dos instrumentos acústicos, criando uma discrepância entre eles. Existem quatro processadores, um para cada canal (saída), permitindo uma pluralidade de variações de som. Metaforicamente, as variações de frequência permitem condições de maior densidade de som que, juntamente com as ações acústicas, oferecem condições de som mais caóticas. Objetivo: 
uma distopia causada por execução acústica e eletrônica, permitindo uma instabilidade de percepção entre os envolvidos na performance.

ADSR: Usando o princípio de envelopamento ADSR (Attack, Decay, Sustain, Release), o algoritmo é capaz de fornecer modificações em tempo real dos referidos parâmetros. Não há possibilidade de seletividade de cada parâmetro em específico. $\mathrm{O}$ algoritmo permite mudar o envelope como um todo, processando o som de forma contínua ou efêmera. Existe a possibilidade de alterar os envelopes de som nos quatro canais de saída, permitindo a singularidade de cada canal. Em LYT, o envelope funciona como um gerador de variações de comprimento. Por exemplo, ataques longos processados nas amostras podem se tornar sons curtos, ou vice-versa. Esta condição impõe transformações significativas no objeto gravado (anteriormente imutável) que permite ações criativas em tempo real.

Delay: O processamento de delay permite que o som seja reproduzido de forma atrasada. $\mathrm{O}$ algoritmo de delay foi desenvolvido para permitir três possibilidades de atraso de som: $5000 \mathrm{~m} / \mathrm{s}, 10.000 \mathrm{~m} / \mathrm{s}$ e $25.000 \mathrm{~m} / \mathrm{s}$. Essas variações de atraso são selecionáveis individualmente para cada canal de saída. Por exemplo, no canal 1 pode ter um atraso de $10.000 \mathrm{~m} / \mathrm{s}$, enquanto no canal $2 \mathrm{o}$ atraso pode ser de 25.000 $\mathrm{m} / \mathrm{s}$. Em LYT este processamento traz mais densidade de som, proporcionando mais complexidade de som. Os atrasos podem se propagar gerando continuamente uma distopia perceptiva de eventos diferidos em tempo real.

Reverb: O processamento permite a simulação do efeito físico da reflexão das ondas sonoras. Em LYT, usamos o reverb como recurso para aumentar a densidade do som. Não há mudanças no padrão de reverberação em tempo real. Usamos um objeto existente em PD ([freeverb]), que processou as mudanças de som necessárias.

Filtros de passa-baixa: é o processamento que permite a passagem de baixas frequências ou atenua (reduz) a amplitude de freqüências maior que a freqüência de corte. Em LYT, os filtros foram usados para remover o ruído de alta freqüência que surgiu ao manipular o áudio em tempo real. Semelhante ao processamento de reverberação, não há manipulação de filtro em tempo real ([lop ]).

Espaçamento Sonoro: Usamos quatro saídas de áudio em LYT. Uma condição que sugere uma relação de som digital para cada fonte acústica. Apontamos para uma condição que, no decurso da comprovisação, as partes sonoras digitais simulam "memórias" acústicas. O algoritmo permite a variação dinâmica (dbs) em tempo real para cada saída de áudio. 


\subsubsection{Plano de Contingência e Modelagem Socioecológica}

Seguindo as proposições da pesquisa de Hannan (2006) sobre comprovisação, que usa gravações de improvisações livres para compor peças concretas, usamos um método similar em LYT. Consideramos as variações dos procedimentos de Hannan. Para fazer isso, usamos como trechos de material amostrado de ensaios ou performances anteriores (recursos materiais) da LYT. Com base nesses materiais, manipulamos as gravações em tempo real usando processamento de som (recursos cognitivos). Esta expansão da metodologia permite o diálogo com trabalhos anteriores em comprovisação (HANNAN, 2006) e abre possibilidades para performances, afinal, lidamos com recursos materiais baseados em improvisação sonora com objetos de som gravados (atividade, SIBERTIN-BLANC et al., 2011).

Pensar na comprovisação objetivando um material concreto a partir de improvisações livres traz uma variedade de novidades para produções artísticas que flutuam entre composição e improvisação, mas parece limitar a singularidade dos recursos cognitivos em uma improvisação.

Quando reduzimos as possibilidades de comprovisação em uma perspectiva deste trabalho, onde a composição é entendida como diretrizes a serem seguidas e a improvisação como contingências periódicas, objetivando um material concreto, como sugerido por Hannan (2014), observamos apenas propostas rígidas e poucas contingências. Mesmo que todo o material tenha sido improvisado livremente e peças tenham sido escolhidas para a produção do material concreto, encontramos um material inalterável que não permite a imprevisibilidade (gelassenheit). A imprevisibilidade parece ser o elemento fundamental nas comprovisações, especialmente quando relacionamos isso com conceitos de ecologia sonora, onde a metáfora da vida concebida por Fujak (2011) é relevante. A improvisação é caracterizada por um evento único dentro da performance. Transformar este evento em algo estático torna-se um registro significativo, mas ignora a expressividade do momento da improvisação (recurso cognitivo, interação do agente). Com este conceito, determinamos que, ao propor uma segunda geração de improvisações eletrônicas com materiais estáticos, como gravações de improvisação, habilitamos novas ferramentas para práticas criativas como visualizadas em Hannan (2006) e permanecemos com a particularidade da performance.

\subsubsection{Processamento em Vídeo como Plano Contingencial}

Semelhante ao conceito de improvisação com processamento de som em objetos estáticos, usamos auxílios visuais para adicionar outra possibilidade de improvisação na performance. Seguindo o critério de uso de objeto gravado, escolhemos uma produção visual que permite uma associação com o conceito estético de LYT (deslocamento periódico de tempo rumo ao caos). Utilizamos uma produção de tintas 
diluídas em água. Na gravação selecionada, vemos gotas de tinta de várias cores sendo derramadas na água. Ao derramar, a tinta adquire uma concentração que se dissolve periodicamente ao longo do tempo. Desta forma, a concentração para a dissolução cria uma metáfora de ordem para o caos. A tinta a ser vertida está em condições coesivas que permitem ser percebidas integralmente. A sua dissolução na água cria um estado de coesão rarefeito, criando movimentos irregulares e menos previsibilidade. Este evento, de um estado coeso a um estado rarefeito, é usado para exemplificar o tempo de Lyapunov (um estado organizado que migra para o caos, com um determinado período de tempo).

Para uma maior percepção do evento, utilizamos o vídeo em processamento lento. Juntos usamos processamento de blur que usa recursos para desfocar a imagem, proporcionando maior dissolução de cores e diminuindo a percepção da organização. A associação entre câmera lenta e blur pode ser controlada em tempo real, trazendo uma organização mais ou menos perceptiva.

Figura 18 - Exemplo de performance em LYT

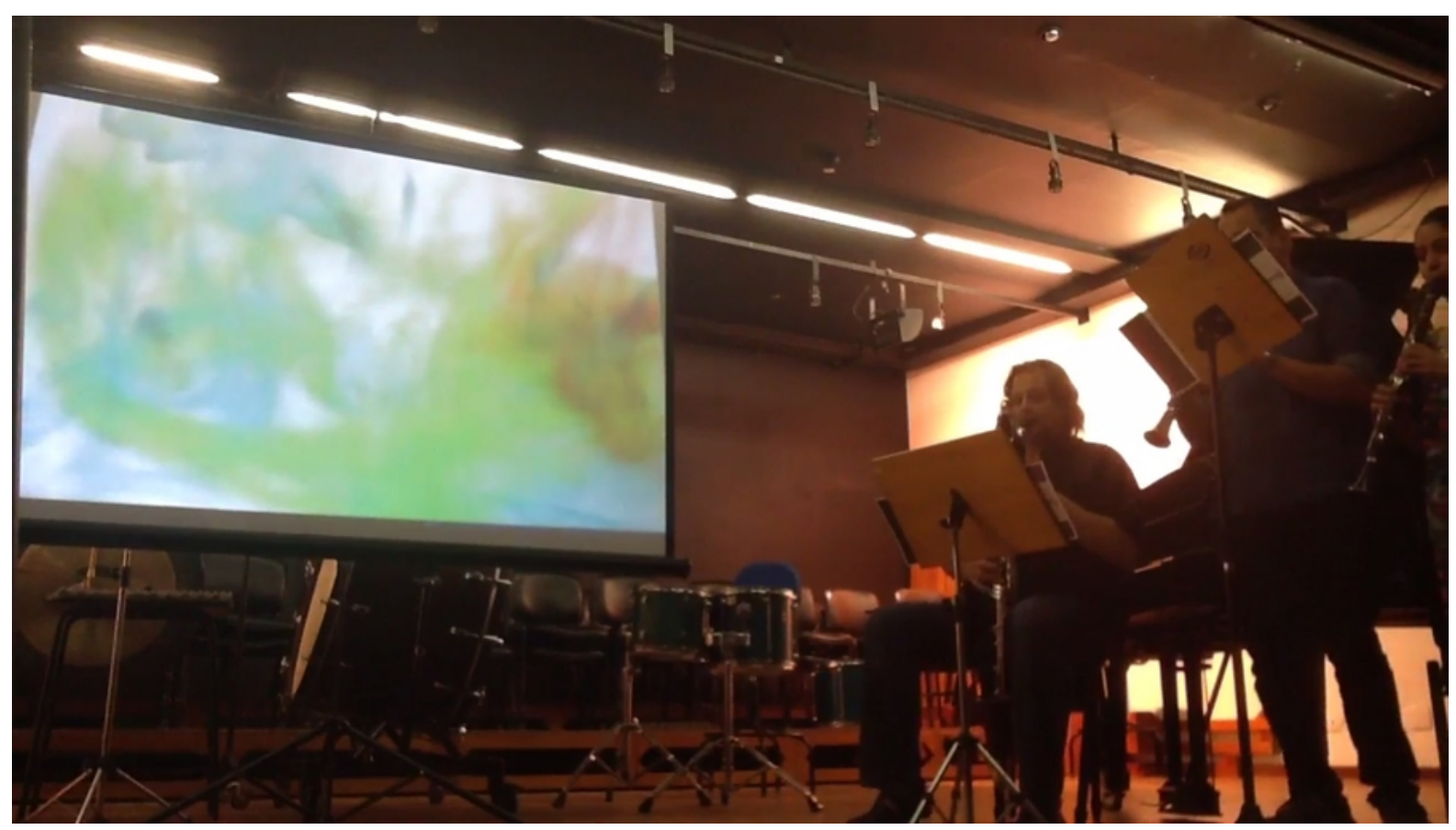

Alterar o processamento visual em tempo real permite que o agente improvise imagens com a intenção de se associar ao conteúdo sonoro. Na verdade, não há hierarquia sobre os conteúdos (som/visual), tanto interpolam e se dissociam durante a performance, criando etapas de percepção variadas. Considerando a possibilidade de trabalhar improvisações com materiais visuais concretos, semelhante aos processos de áudio, possibilitamos uma ferramenta de comprovisação adicional em extensão ao conceito de Hannan (2014). 


\subsubsection{Plano Contingencial em Live Electronics}

Para determinar o plano de contingência (visual e sonora), desenvolveu-se um algoritmo estocástico (recurso de material, plano de diretriz) que traz a imprevisibilidade das ações do agente. As indicações são sugeridas pelo algoritmo em vários períodos de tempo. A variação temporal da indicação também é controlada pelo algoritmo estocástico. Esta variação de tempo varia de $60.000 \mathrm{~m} / \mathrm{s}$ para $180.000 \mathrm{~m} / \mathrm{s}$. Desta forma, o agente tem tempo para improvisar com o processamento até receber uma nova indicação da modificação do processamento. Pode haver repetições de processamento. Esta regulação das indicações pelo algoritmo às vezes limita a expressividade do agente, no entanto, traz um grau de imprevisibilidade (gelassenheit) evitando repetições de ações em múltiplas performances e propiciando singularidades em sistemas sócio-ecológicos contingentes. Essa incerteza sobre qual procedimento será escolhido traz instabilidade à improvisação, mas fornece outros relacionamentos como atenção, presença e uma maior seleção de material.

\subsubsection{Recursos Cognitivos}

Com base nesta linha metodológica, consideramos em LYT que os planos de contingência de conteúdos eletrônicos consistem na utilização de processamento de som em tempo real para a modificação de material gravado (amostras). Os materiais gravados selecionados para a performance de improvisação foram decididos com base nos recursos cognitivos discutidos entre os agentes envolvidos na peça:

- Recursos materiais significativos - clareza dos recursos materiais a serem processados em tempo real sem perdas significativas.

- Interações entre os agentes: Eventos em que os agentes acústicos e eletrônicos consideram expressivo.

- Entidade Gelassenheit - Eventos que trazem imprevisibilidade ao trabalho.

- Instâncias socioecológicas: a semelhança entre sons acústicos e eletrônicos, trazendo considerações importantes para $o$ ato de improvisação na performance.

\subsubsection{Análise de Recursos Materiais e Recursos Cognitivos}

Usaremos como avaliador do comportamento das peças as duas metodologias analíticas propostas para esta dissertação. Usaremos o MDF para questionar o ambiente comprovisatório que está estabelecido na peça. Usaremos o MM para avaliar as ações do agente e como as interações sociais e interações de material ocorrem. 
7.3.5 Processos, Comportamentos e Cenários: Resenha das Transformações da Performance - PMSE/PL - Dinâmica/Impacto/Estágio inicial-Vínculo

O LYT fornece um sistema socioecológico que suporta a premissa dos modelos de síntese ecológica (PMSE) e looping (PL). Em LYT, abordamos as duas propostas ecológicas desenvolvidas nesta pesquisa. Contrariamente aos outros estudos de caso incluídos nesta dissertação, a LYT estabelece dúvidas sobre a forma como os ambientes criativos e de apoio ficam em frente ao uso das duas propostas de modelagem ecológica que defendemos.

A LYT apresenta o uso de material em looping (conteúdo transcrito na partitura), mas ao mesmo tempo permite material variável de alta densidade no sistema através da inclusão de técnicas estendidas nos instrumentos e a reintrodução de material processado por live electronics. A produção deste material mutável é consistente com - PMSE, estabelecendo um sistema macro estático, mas fornecendo singularidades em um microambiente. Observamos, nos testes e na performance, um ambiente de criação de material em micro-estádios, não alterando a natureza macro do objeto em looping. Cada novo material introduzido no sistema possui características singulares, no entanto, essas singularidades existiram em um micro campo contido nas técnicas propostas. Por exemplo, ao selecionar uma técnica de trinado, embora existam semeIhanças entre os instrumentos (o padrão macro permanece em looping), com cada repetição estão incluídos novos detalhes (freqüência, tempo, variações de andamento). Se considerarmos essa relação proporcionalmente a cada instrumentista, observamos o mesmo episódio.

\subsubsection{Entidade de Interface: (MDF) Impactos de Fontes Externas e Internas}

Usando o MDF como ferramenta, visualizamos um conteúdo sonoro principalmente in group. Devido ao plano de diretrizes (partitura/algoritmo) o material é pregnante (relevante) depois que todo o conteúdo é reconhecível e consensual entre os agentes. Contrariamente ao que ocorre normalmente em práticas desta natureza, todas as inclusões de planos de contingência não produzem material residual criativo. Nas contingências LYT, determine as singularidades para cada tipo de recurso material, com pouca descoberta de som. Não há nenhuma condição de adaptação sonora proposta por um agente, como acontece nas práticas de improvisação livre, por exemplo. Portanto, um maior comportamento de variação de som delimitado pelas diretrizes é visualizado em vez do processo de experimentação. Esta circunstância fornece pouco material a ser descartado. Por exemplo, embora o agente performático possa escolher qualquer maneira de fazer um trinado, o material gerado será sempre "trinado". O material pode ser descartado, ou seja, mudança de tipo trinado, velocidade 
e etc. No entanto, a estrutura trinado estará sempre presente, fornecendo um material relevante.

Esta condição propõe limitações ao trabalho consistentes com processos de composição e não comprovisações. Devido a este problema, incluímos enxertos de entidades de gelassenheit. Esses objetos trazem imprevisibilidade à execução, permitindo que mais descartas de material surjam de repente. Esses enxertos são determinados pelo algoritmo estocástico que "rege" os conteúdos executados pela eletrônica em tempo real.

\subsubsection{Comportamento: (MM) - Processo Ecológico/Sociológico/Atividade}

Usaremos o Modelo Mannis (MM) para analisar as ações dos agentes em LYT. LYT usa apenas agentes performáticos. Pretendemos visualizar como estes interagem com trabalhos que utilizam contingências. Os agentes escolhidos geralmente estão familiarizados com repertório contemporâneo e técnicas instrumentais estendidas. No entanto, eles têm pouca experiência com improvisação sonora. Desta forma, esses agentes se encaixam como agentes performáticos parafraseadores.

Observamos durante o processo de ensaio e performance que as diretrizes, como opções de fluxograma (BHAGWATI, 2014), geraram falta de expressividade devido ao processo de escolha em tempo real. No entanto, a mímesis foi apresentada desde o início. Embora as diretrizes de técnica estendida no LYT tenham liberdade de escolha, repetições de padrões e discussões foram visualizadas para "padronização“ de passagens. Acreditamos que esse tipo de abordagem favorece a familiaridade com obras compostas, mas empobrece os trabalhos comprovisados. A padronização foi a solução encontrada pelos parafraseadores para diminuir a expressividade nos processos de escolha. Uma vez que encontraram uma solução satisfatória para uma passagem, ela foi repetida em outras ocasiões. Outra condição que deu aos agentes perda de expressividade está relacionada às ações ocasionais das entidades gelassenheit. Estes produziram uma condição não familiar/padronizada para os parafraseadores, que devem ser resolvidos em tempo real. Os conceitos de percepção-análise-síntese de parafraseadores estabelecem vários tipos de padronização para completar as sínteses. A observação do processo nos permite apontar que as ações de percepção e análise de parafraseadores, aparentemente, consiste em criar mecanismos extremamente delimitados para a síntese. Não há evidências de resultados sonoros durante a performance. Os parafraseadores percebem e analisam as propostas em horário diferido, selecionam os recursos materiais e executam de forma padronizada e expressiva. A seleção de padrões aparentemente ocorre através de:

\section{- Propensão Técnica;}


- Sonoridade;

- Imitação;

Aparentemente, não há seleção hierárquica de análise. Não foi possível incluir agentes performáticos improvisadores nos testes e na performance, no entanto, acreditamos, devido aos outros estudos de caso aplicados neste trabalho, que teríamos resultados significativamente variáveis.

\subsubsection{Instâncias (similaridades) e Observação de Interação entre Agentes}

Lyapunov Time foi uma comprovisação que usa a metáfora de uma teoria matemática para fornecer a experimentação de vários fatores que podem contribuir para a pesquisa em comprovisação e ecologia sonora. Planos de diretrizes (partituras em fluxogramas baseadas em algoritmos de design visual e processamento de som e vídeo) e planos de contingência (técnicas estendidas e inclusão de imprevisibilidade material para uma mudança narrativa) foram desenvolvidos. Consideramos pertinente o uso dos dois tipos de modelagem ecológica que propomos nesta dissertação para a construção da LYT. Desta forma, trouxemos uma expansão para a pesquisa em ecologia sonora que pode ser expandida em pesquisas posteriores.

Em técnicas instrumentais estendidas, acreditamos que sua inclusão na pesquisa de comprovisação é relevante devido à existência de regras em uma condição macro que permite a inclusão de contingências em uma micro instância. A integração de contingências através do processamento de som em amostras de áudio e vídeo leva a uma expansão do trabalho de Hannan (2006), que, em nossa opinião, está mais coerentemente alinhado com os pressupostos de auditoria da Fujak (2011).

Esta técnica permite uma variante das técnicas desenvolvidas e concede uma condição artística relevante. $\mathrm{O}$ uso de material imprevisível controlado por algoritmos estocásticos (materiais Gelassenheit) também traz desafios significativos aos agentes parafraseadores, resultando em condições criativas únicas e relevantes.

\subsection{Estudo de Caso 4: "The Maxwell Demon" (TMD).}

"The Maxwell Demon“ (TMD) é uma comprovisação baseada no experimento mental projetado por James Clerk Maxwell em 1871. ${ }^{27}$ Nesta experiência, o demônio de Maxwell é uma criatura imaginária, projetada para contrariar a segunda lei da termodinâmica. Para simplificar o experimento de Maxwell: uma caixa com um divisor

27 As performances/experimento podem ser visualizadas em:

1) https://www.youtube.com/watch?v=yvyeX4E_IT8\&t=441s

2) https://www.youtube.com/watch?v=Vkva11gMRNQ\&t=254s

3) https://www.youtube.com/watch?v=6sYOe1q7INE\&t=343s 
colocado no meio, separando-o em dois lados, esquerda e direita. Esta partição tem uma porta que pode ser aberta e fechada por um ser imaginário, que passou a ser chamado de "Demônio de Maxwell". O demônio Maxwell abre a porta para permitir que apenas as moléculas mais rápidas fluam para o lado da câmara favorecido, e apenas as moléculas mais lentas fluem para o outro lado, fazendo com que o lado favorecido se aqueça gradualmente, enquanto o outro lado arrefece, reduzindo a entropia . Nossa metáfora artística parte da assunção de simular um evento como esse. Uma vez que uma entidade Gelassenheit produz conteúdo sonoro que pode ou não ser imitado ou contrastado com os resultados produzidos diretamente pelos agentes, essa diretriz parece ser análoga à entidade imaginária de Maxwell. Ou seja, no experimento de Maxwell, a entidade imaginária (demônio) produz ações capazes de separar moléculas em diferentes estágios de temperatura (o que em nossa realidade é impraticável, mas viável a partir de uma perspectiva de física teórica), produzindo uma condição conflitante com a segunda lei da termodinâmica que propõe que ambientes com temperaturas variáveis tendem a equilibrar devido à entropia. Em nossa analogia, admitimos a inclusão de uma entidade desconhecida (gelassenheit) que fornece modificações estocásticas do conteúdo sonoro do meio ambiente sem controle biológico. Embora cada agente contido neste ambiente tenha uma gama de possibilidades sonoras para escolher, a predominância da entidade gelassenheit (via pregnância, dinâmica ou sonora) introduz a indução de seleção de recursos materiais aos agentes no sistema, gerenciando-o. Assim, por mais entrópico que seja o ambiente (devido às escolhas dos agentes), tenderá a uma organização macro, guiada pela influência da entidade Gelassenheit.

Nesta diretriz, o que vamos propor nesta performance/experimento é préconstruir um ambiente em que os agentes e as máquinas se relacionem de forma sônica de maneira mais ou menos caótica. Vamos apontar como essas relações ocorrem e se uma estrutura não-viva como um algoritmo é capaz de organizar atividades caóticas através de um aspecto estocástico. Seguindo os conceitos de comprovisação estabelecidos neste trabalho, onde criamos um plano de contingência e diretrizes para definir quais eventos são pré-projetados, testados e experimentados (compostos) e quais ocorrerão de forma inesperada e planejada (improvisação), tentaremos demonstrar os principais fatores que compõem "The Maxwell Demon“.

\subsubsection{Recursos Materiais e Métodos (Plano de Diretrizes)}

Seguindo os procedimentos de Maxwell como inspiração, utilizamos dois tipos de agentes, aqueles com conhecimento tradicional da música (agentes performaticos) e aqueles com pouco ou nenhum conhecimento (incisos). Desenvolvemos dois níveis 
de materiais que podem ser usados por ambos:

\subsubsection{Recursos Materiais Eletrônicos}

a) Celulares

Todos os agentes têm um celular com um patch adaptado desenvolvido em Pure Data (PD) (PUCKETTE, 1997) e adaptado para o aplicativo MobMuPlat ${ }^{28}$ (IGLESIA, 2016), com os mesmos recursos de som. Neste patch, até quatro osciladores de síntese de FM podem ser usados em conjunto, com opções para modificar parâmetros como a frequência de altura, duração e processamento de áudio: delay. Consideramos a possibilidade de controlar a dinâmica do som através do volume do telefone celular. Todos esses recursos são controlados tocando na tela do telefone e podem ser ativados e desativados a qualquer momento. Na premissa do uso de celular como ferramenta de som, procuramos combinar a condição de "interface" instrumental. Ou seja, embora haja disparidades de conhecimento musical entre os agentes, ambos têm o mesmo nível técnico instrumental ao tentar produzir sons. As discussões sobre a interface podem ser levantadas neste momento, no entanto, acreditamos que escapa ao escopo da pesquisa. Nossa perspectiva é gerar um instrumento capaz de produzir sons e que seja:

1) fácil de manipular;

2) fácil reconhecimento empírico;

3) comum a todos os agentes (celular);

28 Aplicativo desenvolvido para celular capaz de rodar patchs desenvolvidos em Pure Data. Fonte: http ://danieliglesia.com/mobmuplat/ 
Figura 19 - Interface do patch de celular de "The Maxwell Demon"

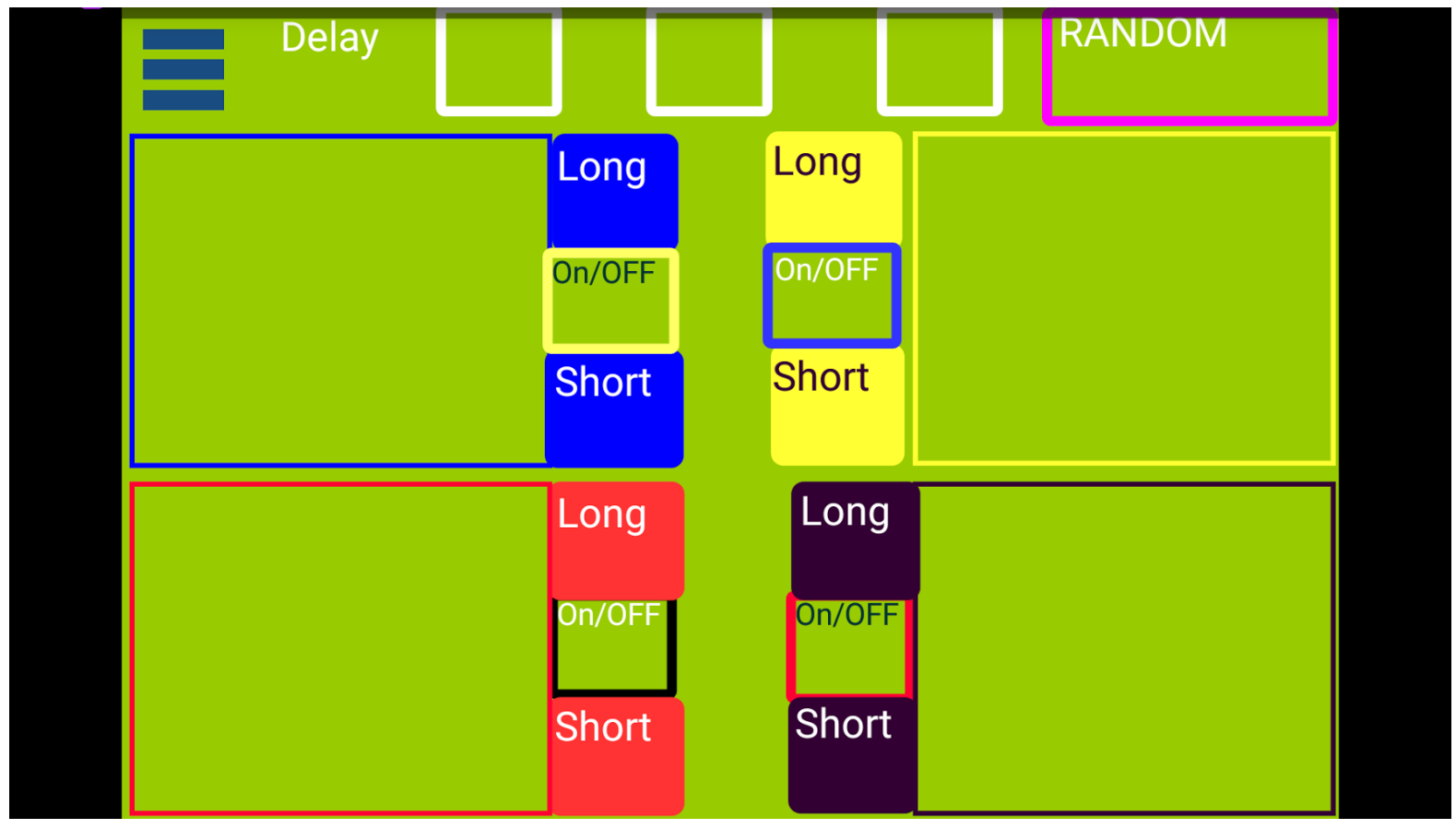

É relevante mencionar que não consideramos o uso de nenhum mecanismo de amplificação de som (como amplificadores externos conectados ao celular). Buscamos criar um envolvimento individual de cada agente com sua ferramenta e ambiente. Este parâmetro parece exigir maior atenção dos envolvidos, nos processos de hierarquia e pregnância do material sonoro, tratados à frente.

\section{b) Computador}

Para este fim, desenvolvemos no software Pure Data um patch que possui os mesmos recursos sônicos que existem nos celulares, mas é executado em um notebook. No entanto, em vez de serem controlados por agentes, são algoritmos estocásticos que determinam quando e como os eventos sonoros ocorrerão. Recordando, os algoritmos, portanto, podem controlar os osciladores de síntese de FM em polifonia ou de forma singular, com possibilidades de variação em dinâmica, altura, duração e processamento de áudio (delay).

É importante ressaltar que, para minimizar o nível de previsão de eventos, foi adicionado um sistema aleatório que controla o tempo dos eventos. Por exemplo, as mudanças na altura do som podem ocorrer inicialmente a cada 1 segundo, e mudar aleatoriamente para 10 segundos sem uma previsão pelos agentes. $O$ algoritmo, portanto, tem uma "independência" de ações temporais, sendo guiado pelas variações propostas pelo software. Obviamente, não usamos o termo "independência" no sentido da intencionalidade, mas sim no pressuposto de que não está orientado em tempo real por ações biológicas. 
Na nossa visão comprovisacional desta performance/experimento, buscamos um processo de imprevisibilidade de ações através da ausência de controle humano em tempo real. A máquina usará, portanto, as escolhas feitas em um plano de diretrizes previamente desenvolvido (algoritmo) para que, no momento da performance, possa simular um plano de contingência. A interação entre máquina e agentes é o ponto de interrogação fundamental.

\subsubsection{Plano de Contingência e Modelagem Socioecológica}

Seguindo a inspiração no experimento de Maxwell, o algoritmo projetado para ser executado em um computador seria o "demônio" que controla o meio ambiente. Ou seja, nesta proposta, usamos algoritmos estocásticos como ferramentas para gerar recursos sonoros e observamos como os agentes interagem neste ambiente controlado e quais os impactos de um sistema socioecológico mais ou menos caóticos.

A orientação inicial dada aos agentes (que é considerada uma diretriz) é que eles podem se mover como desejam ao longo do espaço e usar o celular para produzir sons. O trabalho começa e termina quando um som de sino (síntese FM) é ouvido. Este som de sino é acionado pelo patch do computador e determina o início/fim da performance/experimento. Concebemos esse modo de sinalização para determinar uma ordem narrativa de início e fim. Todo o trabalho ocorre em nove minutos. Nesse sentido, forçamos através de uma diretriz uma estruturação narrativa. Estas são as únicas duas regras, todo o conteúdo sonoro que ocorre durante o período de toque dos sinos são contingências resultantes de interações entre agentes $x$ agentes e agentes $x$ máquina. Em outra perspectiva, usamos um plano de contingência amplo baseado apenas nas interações entre agentes e seus movimentos e gestos no espaço.

Quanto à abordagem do movimento sugerida aos agentes, é relevante ressaltar a diversidade da espacialidade do som alcançada através do uso de telefones celulares como instrumentação sonora. Nossa performance/experiência foi realizada em um estúdio de tamanho médio, aproximadamente 10×10 metros. Usamos oito agentes entre performáticos (5) e incisos (3). Infelizmente, não foi possível usar um grupo de controle com uma divisão igual. No entanto, esta condição proporcionou condições únicas de interação que serão discutidas. Os agentes se movimentaram pelo meio ambiente, gerando novas formas de interação entre o meio ambiente e entre indivíduos. Essa mobilidade proporcionou um ambiente dinâmico e altamente concentrado, onde a atenção está constantemente focada na mudança do processo dinâmico. 
7.4.3 Processos, Comportamentos e Cenários: Resenha das Transformações da Performance - PMSE - Dinâmica/Impacto/Estágio inicial-Vínculo

Definimos a proposta de modelos de síntese ecológica (PMSE), conforme descrito mais detalhadamente no capítulo III, para conceituar essa comprovisação ecológica. Consideramos o uso deste modelo devido à sua abordagem de geração constante de material inédito em uma relação direta com as interações de agentes e meios. Neste viés, consideramos que todo o material que é produzido nesta proposta raramente se repete, proporcionando condições de pouca pregnância de som e massas sonoras sem forma definitiva.

Com o toque do sino, o computador inicia seus parâmetros pré-definidos e gera condições de som, ou seja, selecione osciladores: (polifônicos ou não), modifica alturas, dinâmicas, duração e processamento. O computador é o único que está conectado às quatro caixas, distribuídas no local, garantindo uma "hierarquia" sônica sobre o celular. Esta hierarquia garante nossa relação com o experimento de Maxwell, produzindo uma "entidade" que procura determinar se, através da seletividade de som, as recorrências de som geradas pelos agentes tendem a ser mais organizadas.

Todas as performances/experimentos foram realizadas no mesmo dia (21 de abril de 2017). Entre as performances/experimentos, houve aproximadamente 10 minutos de diálogos. Perguntas e respostas para questões avaliativas sobre o processo foram aplicadas com base nos processos de grounded theory no viés da perspectiva ecológica proposta por Schulte-Fortkamp; Fiebig (2006). Consideramos um questionário semiestruturado, com perguntas capazes de gerar discussões entre o grupo de controle e as observações capturadas nas gravações de vídeo das performances/expe

Questionário Semi-Estruturado

1) Quais foram as principais formas de interação (meio e agentes) percebidas?

2) Foram percebidos momentos de hierarquização de padrões de som ou pelo menos determinantes?

3) Quais são os principais desafios ao usar um instrumento sem precedentes em uma performance?

4) Quais as estratégias escolhidas?

As respostas foram diluídas nas descrições de cada performance/experiência com a intenção de oferecer um recorte específico de cada evento. As respostas não foram objetivadas em um questionário estruturado porque nos concentramos na disposição qualitativa em que as sensações e afecções experimentadas pelos agentes são tratadas. Esta perspectiva parece trazer conteúdo mais relevante para a discussão 
dessa pesquisa do que a simples formalização das respostas. Portanto, consideramos uma expansão da abordagem de Schulte-Fortkamp; Fiebig (2006), isto é, usamos as interpretações do grupo de controle de uma maneira "não estar em um experimento", mas em "uma performance". Acreditamos que um questionário estruturado pode não capturar a informação do experimento, limitando as interpretações posteriores das questões, provenientes do ambiente de performance.

\subsubsection{Instâncias (Similaridades) e Observação de Interação entre Agentes}

\section{Performance/Experimento 1}

A primeira performance/experimento levou dez minutos e quatro segundos. Nesta primeira versão, não possuímos todos os agentes no grupo de controle. Nós tínhamos seis indivíduos. Entre eles, quatro músicos, uma mulher e três homens, com idade entre 26 e 34 anos. Também tivemos dois não-músicos com 26 e 32 anos. Em geral, todo experimento teve uma condição exploratória clara. No primeiro minuto, alguns indivíduos mantiveram seus lugares e procuraram descobrir as possibilidades do instrumento. Pelo menos três dos agentes permaneceram nessas condições, sendo dois músicos e um não-músico. Os outros três indivíduos escolheram abordagens baseadas em gestos. Estes, dois músicos e uma musicista, se moviam pelo meio ambiente e/ou usavam o corpo como uma maneira de alterar o som. Ou seja, Ou seja, gestos com o braço que segurava o dispositivo, fechando e abrindo a saída de som do telefone e tentando amplificar o som.

\section{Figura 20 - Cena da primeira performance/experimento}

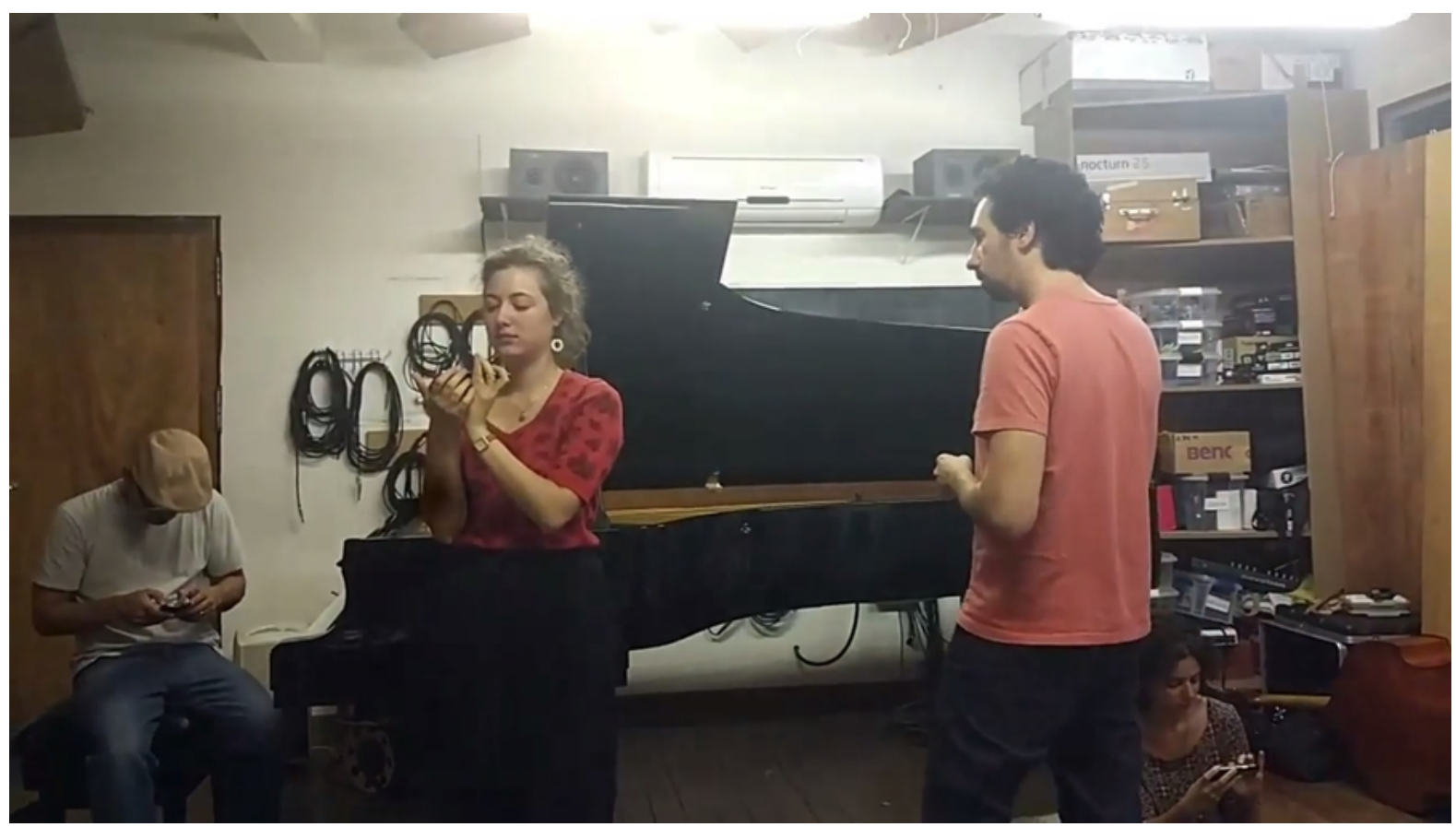


A partir do segundo minuto, cinco indivíduos adotaram os gestos como uma abordagem criativa. Aparentemente, a imitação foi considerada relevante pelos outros membros, que começaram a usar as mesmas técnicas gestuais desenvolvidas anteriormente por outros indivíduos. Apenas um não-músico permaneceu no processo estático, avaliando as possibilidades de som. Após o quarto minuto, três indivíduos pararam seus gestos e se concentraram em descobrir recursos materiais potencialmente sonoros. Pequenas interações sônicas começam a aparecer através de relações gestuais. Tais interações não constituem pregnância. Em cerca de cinco minutos e trinta segundos, começamos a visualizar as interações com o meio ambiente, o aparelho sendo colocado dentro de estruturas, como um piano, um banco, no chão. Elas apresentam baixa pregnância. É relevante ressaltar que nenhum agente notou o toque do sino nos sete minutos, continuando a explorar os sons do dispositivo e as possibilidades gestuais. Em geral, quase nenhuma interação ocorreu intencionalmente entre o algoritmo estocástico e os agentes.

Em discussão com o grupo de controle após a performance/experimento, utilizamos questões para provocar as interpretações dos agentes. Os agentes imersos com seus dispositivos não perceberam que o conteúdo de som produzido pelo computador era dinamicamente maior que o conteúdo desses. Às vezes, percebemos semelhanças de som entre agentes e algoritmos, mas os agentes não demonstraram entender essa relação. Através da entrevista, obtivemos relatórios de não percepção da influência do algoritmo sobre as ações, no entanto, através da observação de vídeo, podemos perceber imitações. Podemos sugerir que durante a atividade exploratória (KELLER et al.) Ou atividade (SIBERTIN-BLANC et al., 2011), os agentes perdem a capacidade de atenção múltipla. O foco cognitivo da atenção se limita a descobrir como o instrumento funciona e como é possível trazer algum tipo de expressividade ao evento. Os agentes foram informados de que esta era uma performance de livre improvisação, não que eles estivessem sendo analisados através de um experimento. Esta condição tornou possível denunciar intimidação devido ao medo de "cometer erros" na produção de sons. Um dos participantes relatou um termo de "aprendizado em performance“, afinal, ele deve aprender o instrumento enquanto executa o mesmo, causando desconforto e falta de expressividade.

Durante a primeira performance/experimento, podemos apontar a baixa geração de material criativo relevante, no entanto, muito resíduo criativo foi processado. Não havia hiera

\section{Experimento 2}

A segunda performance/experimento leva aproximadamente nove minutos. Um fator a ser apontado é que, nesta segunda etapa, os agentes se aproximaram da estrutura temporal planejada. Não houve abstração totalitária dos agentes em relação 
ao toque do sino que determinou a marcação temporal do início e fim como ocorreu na primeira ocasião. No segundo experimento, tivemos a inclusão de mais um músico (36) e uma mulher não musicista (34).

Pelo menos uma observação pode ser apontada em detrimento do comportamento dos agentes na segunda performance/ experimento: maior estágio de descoberta de som, evitando explorar as potencialidades de ambientes e gestos. A única divergência foi da não-musicista que não participou do primeiro experimento. Sua abordagem foi semelhante aos outros agentes na primeira ocasião. É relevante ressaltar que, à medida que os outros agentes não interagem nas mesmas condições de gestualidade, houve uma adaptação rápida da não-musicista que mudou a abordagem para um aspecto de imitação dos outros indivíduos.

Nos minutos dois até cerca de cinco minutos, as primeiras extensões das técnicas corporais são acopladas aos celulares (uso de recursos vocais e condições de abafamento ou movimento do dispositivo). Tanto músicos como não músicos começam a observar outros agentes e buscam expandir as condições de som através da imitação de gestos. Este tipo de imitação proporcionou interações como contrastes e repetições sônicas e gestuais. Os aspectos rítmicos foram iniciados devido a imitações. Podemos ressaltar que o conteúdo é criativamente mais relevante do que o observado no primeiro experimento. $\mathrm{O}$ aspecto de descoberta sonora/técnica foi minimizado, com uma orientação geral focada na imitação de processos gestuais. Outros parâmetros musicais também foram minimizados, com predominância de gestos.

Esta observação é consistente com os processos citados por Ferraz; Keller (2014) no MDF. Quando os agentes adquirem conhecimento da instrumentação, técnica e conteúdo, as possibilidades geradas aumentam a relevância e a pregnância do material (neste contexto: padrões rítmicos e gestos). Houve poucas interações com o meio ambiente na performance/experimento 2. Os agentes não se moveram como ocorreu na primeira apresentação. Quando houve movimento, estes foram mais organizados do que os observados na primeira ocasião. 
Figura 21 - Cena da segunda performance/experimento

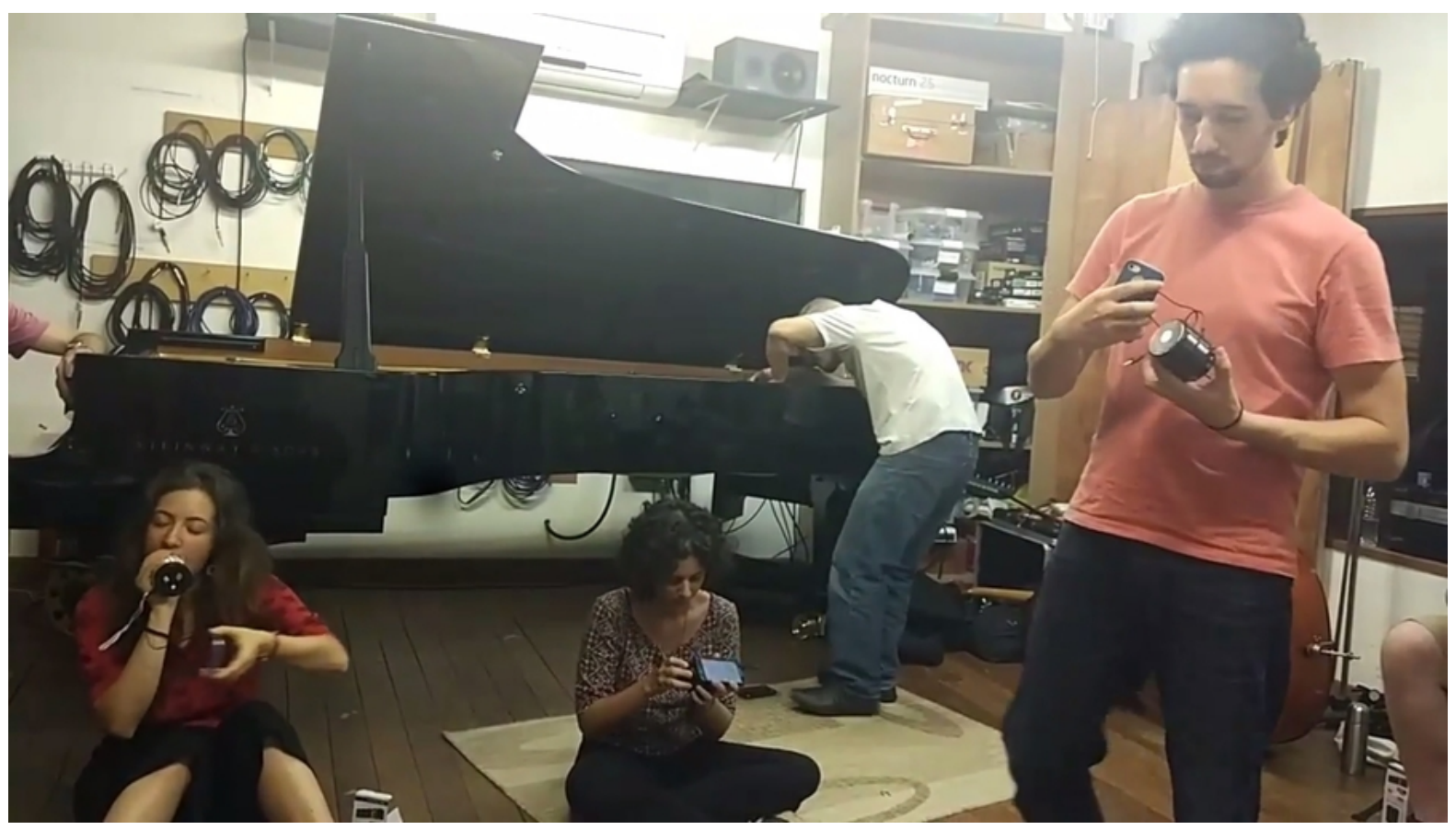

O algoritmo estocástico reproduziu a condição do primeiro experimento. Ele gerou conteúdo descartado e selecionado pelos agentes. Observamos momentos como 3:12 a 4:26 minutos, uma homogeneidade no som. Esta característica pode ser apontada como um fator de demonstração de que os agentes se adaptam ao material gerado pelo algoritmo estocástico. Podemos fazer essa afirmação porque entendemos que a dinâmica do algoritmo era superior às possibilidades dos celulares, no entanto, o som produzido pelos celulares ainda estava determinado (audível) e singular. A homogeneidade do som é, portanto, o resultado de uma confluência entre ações criativas geradas por ações estocásticas e intencionais dos agentes.

Um fator relevante foi o isolamento físico dos agentes. Embora no segundo experimento obtivéssemos interações pontuais, não houve interações gestuais. Mesmo quando observamos a imitação de gestos (um agente percebe um gesto e o assume como relevante), não houve interação entre esses indivíduos, apenas a imitação como mecanismo de geração de recursos materiais e não como forma de relacionamento. Do sexto minuto até o final da performance, encontramos uma perda gradual de interação e um retorno à produção de muitos materiais.

\section{Experimento 3}

As abordagens visualizadas no terceiro experimento tiveram características únicas. Devido ao conhecimento dos recursos materiais (interface do dispositivo, suas possibilidades técnicas e escolha de som), a performance/experimento alcançou um 
status de interação e criatividade no primeiro minuto. Todos os agentes foram dedicados a trabalhar o conteúdo sonoro de maneira estável (sem deslocamentos pelo meio ambiente). Como nas experiências anteriores, as mesmas técnicas foram visualizadas, como características gestuais, interferências dinâmicas, uso de objetos ou locais para projeção ou alteração de som. No entanto, no Experimento III, encontramos os agentes trabalhando as técnicas de forma mais coesa, selecionando recursos materiais de forma mais objetiva. Outro fator visualizado foi a tentativa de interação através de semelhanças. Nesse sentido, sons longos ou alturas parcialmente definidas (graves e agudos) formaram a principal via de interação.

Figura 22 - Cena da terceira performance/experimento

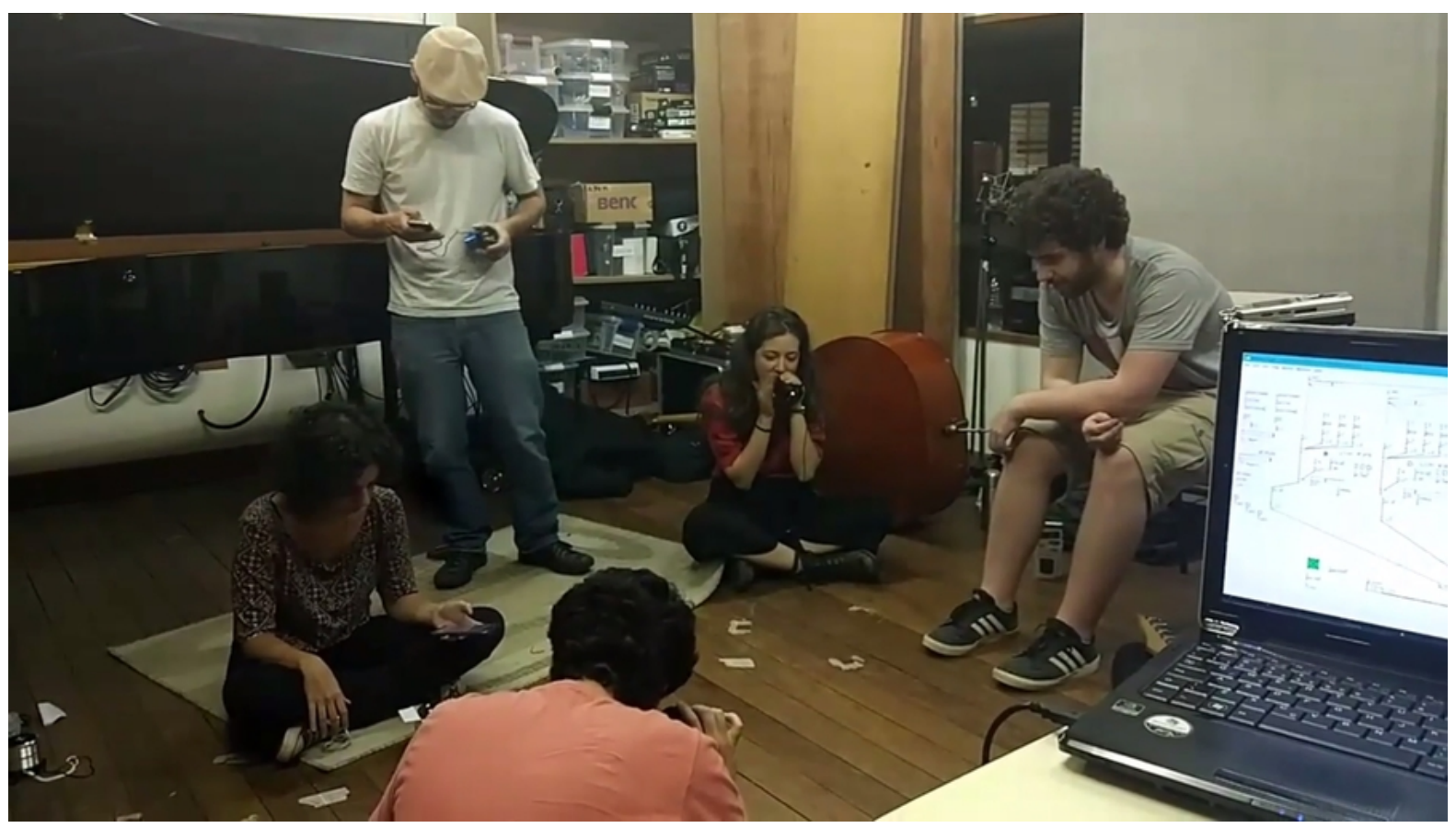

No experimento III, observamos duas características que não eram anteriormente presentes: ausência de ações por agentes (sem produção de som, observação do meio ambiente ou outros agentes) e troca de dispositivos entre agentes. De fato, o primeiro caso parece fortalecer os pressupostos de Mannis (2014), que argumenta que a percepção-análise-síntese tende a ser o principal recurso cognitivo encontrado em tais ambientes. Acreditamos que as "não ações", especialmente em um quadro de "não agir para perceber e analisar", tendem a ser relevantes para o contributo dos aspectos criativos da prova. Um dos agentes (músico) ficou cerca de três minutos nessa condição. Quando decide agir, possui uma maior variedade de recursos técnicos a partir da análise da percepção das ações de outros agentes. Um dos recursos criativos adicionados por este agente, em cerca de 3:32 min, foi a adição de recursos rítmicos à 
comprovisação. Através de ostinatos, esses padrões estabelecidos foram percebidos por outros agentes que acabaram interagindo nessa mesma frente. A partir desse momento, os gestos corporais que simbolizam "danças" são visualizados (3:45). Várias camadas rítmicas são introduzidas por vários agentes, desencadeando um tipo de jogo ou diversão improvisada. A priori, esse tipo de jogo foi iniciado por um músico e abrangeu outros dois músicos que, ao perceber o relacionamento de interação, construíram um pequeno grupo. Este grupo, aparentemente, joga uns com os outros e não permite novas pregnâncias provenientes de agentes externos. Acreditamos que esse tipo de comportamento tende a ser um mecanismo de geração de hierarquia no sistema. Mesmo o algoritmo estocástico com uma dinâmica maior sugerindo materiais, o grupo permaneceu fechado reduzindo os níveis de entropia sônica proporcionando um reconhecimento fácil dos padrões que se seguiram. Observamos alguns padrões que confirmam nossas hipóteses, como gestos marcando pulso, células rítmicas e interações imitativas.

Nos 5:48 minutos, visualizamos um evento ainda inédito nos experimentos anteriores, a diminuição da geração de som. Até este ponto, todos os indivíduos sempre produziram sons e não utilizaram do silêncio como um recurso. A partir deste ponto, visualizamos uma diminuição da dinâmica com o agente reduzindo o processo ou mesmo parando totalmente de tocar. Com a redução da dinâmica e a produção de recursos materiais, podemos observar uma maior organização rítmica através de imitações de células rítmicas. Cerca do oitavo minutos, visualizamos uma amplificação do grupo inicial, agora encontramos cinco músicos interagindo, no entanto, não observamos interações sonoras com não músicos. No nono minuto, temos três agentes (2 músicos e 1 não-músicos) que intervêm em suas ações para assistir apenas as ações gerais, principalmente do grupo formado. $O$ grupo é reduzido a dois músicos, que finalmente aceitam a inclusão de um não-músico. O experimento termina com a dissolução do grupo.

É relevante ressaltar que todas as mulheres ouviram o sino que determinou o fim do experimento, algumas decidiram continuar suas ações e outras interromperam as ações. Dos cinco homens na experiência, apenas dois ouviram o sino e destes, nenhum interrompeu as ações. Consideramos que o material observado é muito escasso, a fim de hipotetizar o que ocorreu, no entanto, acreditamos que isso pode revelar-se um foco em outras performances/experiências com outros grupos de controle.

7.4.5 Relações Permanentemente Estrutural - Relações Permanentemente NãoEstrutural - Resultado de Ações Performáticas - Mimese 
Realizamos a performance/experimento por três vezes e conseguimos uma mudança significativa nas três execuções. A produção de recursos materiais pelo computador proporcionou aos agentes, tanto performáticos quanto incisos, o relacionamento com a imitação. Embora possamos observar momentos de divergência entre os agentes performáticos, onde buscavam maior "independência" (recursos cognitivos), a maioria dos envolvidos eventualmente imitava os recursos materiais executados pelo computador. Nesse sentido, a partir de nossa perspectiva socioecológica, consideramos que houve uma ordem sonora quando pudemos perceber e apontar escolhas intencionais por parte dos agentes: equivalência de som (dinâmicas, alturas semelhantes e assim por diante). E a entropia sonora quando a diversidade do som é tão singular e individual que cada ação se torna complexa, produzindo massas de som.

Nossa performance/experimento teve instâncias de falta de novas informações computacionais. Ou seja, o computador deixa de reproduzir padrões de som. Este "silêncio" é uma variante, indeterminada, afinal, é controlada por um algoritmo estocástico. Durante esses períodos, a entropia sonora tornou-se evidente. A ausência de uma "hierarquia" pelo algoritmo fornece duas condições:

1) Grupos menores se encontram e trocaram contingências de som equivalentes;

2) Exploração de novas condições de som produzindo maior variedade.

\subsubsection{Comportamento: (MM) - Processo Ecológico/Sociológico/Atividade}

Ao usar o modelo de MM para análise qualitativa do trabalho, observamos que tanto os agentes performáticos quanto os incisos se dividem de forma muito semelhante no processo de percepção-análise-síntese, causando um nivelamento técnico/criativo durante o processo. Duas condições parecem ajudar esta situação:

1) O uso de instrumentos sem domínio prévio de todos os agentes;

2) A quase ausência do plano de diretrizes em proporção ao plano de contingência.

Neste tópico, observamos que, sem uma diretriz definida de ação e, portanto, minimizando as regras para interações visuais e gestuais dos agentes, estes procuram nas relações de som alcançar alguma condição de ordem. Em ambas as classificações de agentes, sugeridos neste trabalho, performático e inciso, observamos essa configuração. Ambos estão inclinados a perceber qual conteúdo de som está em "hierarquia" (pregnante), - analisar suas opções e escolher sintetizar recursos materiais similares (imitação). Entre os agentes incisos, e sua subdivisão: apreciadores e produtores, esta 
condição é quase unânime. Mesmo quando há silêncio por parte do computador, (redução do conceito de hierarquia), estes procuram formar ou criar grupos de parâmetros de som semelhantes. A inevitabilidade da ordem sonora parece ser altamente relevante neste grupo. Embora pequenas variações tenham sido observadas, os incisos procuraram um plano contingente mais ordenado e em congruência com todos os indivíduos. Entre os agentes performáticos, visualizamos um quadro semelhante de ordem, no entanto, encontramos algumas distopias em comparação direta com os incisos.

Os parafraseadores geralmente encontram soluções semelhantes aos incisos, ou seja, definem os planos de contingência em imitação através de interações sonoras. Podemos observar que os parafraseadores às vezes se tornam pontos hierárquicos de grupos de incisos. Aparentemente, sem a existência de uma hierarquia maior (computador/demônio) alguns parafraseadores decidem gerar recursos materiais hierárquicos para a organização da obra. Suas ações demonstram que as escolhas de contingência bem definidas são acessíveis para todos os envolvidos. Variações de som mais complexas só são observadas quando há um grupo maior que domina o sistema socioecológico estabelecido.

Obviamente, o processo de experimentação é decisivo no estabelecimento de uma interação consensual significativa. Na primeira experiência, as relações eram pouco consensuais, afinal, as interações foram substituídas por exploração instrumental, ambiental e sonora. No segundo experimento, as ações de síntese começam a ser determinadas pelos recursos cognitivos, permitindo algumas condições de interação, com ênfase na imitação. No terceiro experimento, os recursos materiais e cognitivos estão alinhados, permitindo interações mais significativas e complexas. Neste tópico específico, estamos lidando com as interações agente vs. agente. No quesito agente vs. máquina, encontramos interações não consensuais em todas as experiências.

\subsubsection{Entidade de Interface: (MDF) Impactos de Fontes Externas e Internas}

Usando MDF como um recurso analítico quantitativo, podemos apontar grandes variáveis criativas durante a execução do TMD. O resíduo criativo tende a aumentar ou diminuir a quantidade em contraste com a existência de mais ordem ou mais entropia. Quando a hierarquia não é definida, a aparência da originalidade do material e dos resíduos criativos é alta e quantitativa. Este quadro permanece enquanto os agentes não estão em grupos. Desde a reunificação, eles encontram maneiras de estabelecer os mesmos campos epistêmicos, empurrando conteúdo mais aglutinado e em consenso, reduzindo a originalidade e os resíduos criativos, aumentando a relevância (pregnância) e a hierarquia. Às vezes, vemos a formação de mais de um grupo. Nessas situações, não observamos nenhuma tentativa de interação ou conflito entre os grupos. Talvez possa ocorrer interações e/ou conflitos caso a performance/experimento seja estendida 
ou se o computador permanecer em silêncio por mais tempo.

O que parece relevante ressaltar é que todos os envolvidos buscam a impregnação de algum material ou recurso cognitivo quando livre de um processo hierárquico (neste caso, o algoritmo). Em nenhum momento observamos um estado de entropia total. Ou seja, os agentes quando perdem o sentido de diretriz aparentemente não consideram o momento como um "estado sonoro caótico por completo", pois encontram outros mecanismos para estabelecer ordem, hierarquia e pregnância. Isso nos leva a deduzir que, ao examinar uma estrutura, visando padrões completamente entrópicos, essa estrutura não parece existir quando admitimos apenas ações baseadas em planos contingenciais e agentes.

Em outras palavras, o que o experimento parece sugerir é que, quando os agentes se encontram em um processo onde eles podem levar intencionalmente 0 sistema há um estágio completamente caótico, mas desconhecem esse fato, não o fazem. Desta forma, o que ressaltamos é a exigência dos planos de diretrizes para definir uma simulação de condição entrópica. Embora esta retórica pareça paradoxal, alcançar massas de som caóticas através de diretrizes parece ser viável. O que observamos, é que, em comprovisações, ações totalmente caóticas não ocorrem entre o meio ambiente e agentes de forma natural. O que acontece é uma simulação de caos gerada pelos agentes quando se propõe ao conceito de caos sonoro. Esta simulação pelos agentes produz muitos resíduos criativos, mas o processo é intencional. Quanto mais a diretiva do "caos" é adicionada, mais o sistema se torna heterogêneo (outgroup), ou seja, menos campos epistemológicos comuns são verificáveis, produzindo material muito original e menos relevante. Quando o caos é inserido no sistema como uma contingência, as interações tornam-se mais homogêneas, produzindo menos originalidade e maior solidez (relevância). 


\section{Discussão e Considerações Finais}

O objetivo da pesquisa deste mestrado foi investigar as possibilidades de incluir a improvisação em práticas ecológicas. Em geral, nossa pesquisa não encontrou na literatura uma base de trabalho relevante nesta frente. As práticas ecológicas sempre possuíam uma característica composicional, ignorando de alguma forma o papel das condições improvisadas existentes nos ambientes ecológicos. De acordo com nossa pesquisa bibliográfica, nenhum autor/compositor da área dedicou esforços para considerar práticas improvisadas em paisagens sonoras, ecocomposição ou mesmo ecologia sonora. Na verdade, isso parece ser um trabalho árduo que representa desafios. Acreditamos que a falta de propostas de improvisação em prática ecológicas, está diretamente ligada à dificuldade de manipular esses conteúdos em tempo real. Em uma perspectiva macro, toda a ecologia está em um ponto "composto". Encontramos todos os agentes já predispostos à sua condição. No entanto, lidamos com ações dinâmicas entre todos esses agentes. Cada ação dinâmica provoca uma reação que determina o meio ambiente como um ecossistema. A transposição do ambiente de som dinâmico para um objeto fixo, como uma gravação, parece ser uma possibilidade, mas elimina toda a diversidade e potencialidades de um sistema "vivo". Costa (2014) é um dos pioneiros a pensar em práticas de improvisação livres como um tipo de ecologia sonora. Esta prerrogativa permite uma nova maneira de repensar práticas improvisadas em ambientes de som, avaliando uma ecologia sonora através dos comportamentos de indivíduos dentro do meio ambiente. Apoiado por pensadores como Solomos (2012), que trabalham com o conceito de que a ecologia sonora seria o todo, um estado de "estar", abordamos a premissa de pensar sobre a ecologia sonora como existente no campo da percepção. O que queremos dizer é que a ecologia sonora pode ser qualquer evento dentro da percepção de um indivíduo. Ou seja, os sons de uma floresta, mar, metrô, salas de concerto, sessões de improvisação livre só existem como ambiente porque existe algum indivíduo para perceber cada ação e reação de cada sistema.

Nesta premissa, toda ecologia sonora propõe ações causadas por efeitos diretos ou indiretos. Mas é através da percepção que definimos que algo está acontecendo ou não. Em um breve alinhamento com os pensamentos de George Berkeley em seu Tratado sobre os Princípios do Conhecimento Humano (1975), ele propõe:

[...]Mas, digamos que para você certamente, não há nada mais fácil para mim do que imaginar árvores, por exemplo, num parque [... ] e sem ninguém por perto para percebê-los. [...] Os objetos do sentido que só existem quando são percebidos; as árvores são, por conseguinte, no jardim [...] não é mais do que quando há alguém por perto para percebê-los.[... ] BERKELEY (1975). 
Embora estejamos usando uma metáfora para definir os parâmetros de ecologia sonora abordados neste trabalho, acreditamos que esta é uma questão relevante para a área. Quando introduzimos o conceito de improvisação em ambientes ecológicos, devemos levar em consideração que todas as atividades dentro deste sistema serão influenciadas de alguma forma. Fujak (2011) levanta uma metáfora onde ele sugere que práticas que combinam composição e improvisação podem estar associadas a aspectos da vida. Em outras palavras, a Fujak propõe que tanto quanto planejamos as ações que queremos tomar, há um fator de imprevisibilidade que pode mudar todo o processo.

Decidimos formalizar essa metáfora, abordando a metodologia da comprovisação (composição e improvisação) para estabelecer conteúdos capazes de serem investigados. A comprovisação é defendida por vários autores de diferentes maneiras e com diferentes abordagens, no entanto, há algum consenso sobre a existência de estruturas mais ou menos compostas ou improvisadas. Os autores mencionados no Capítulo II abordam técnicas e questões filosóficas sobre comprovisação que ajudaram a formalizar algumas diretrizes para este trabalho.

Consideramos coerente abordar a comprovisação em ensaios sobre improvisação em ambientes ecológicos a partir da premissa de que toda improvisação seria uma contingência. Ou seja, uma possibilidade de que algo aconteça. A improvisação sonora em nosso trabalho foi entendida como ações que podem ocorrer em ambientes que possuem suas próprias regras. Voltando à metáfora de Fujak, as regras estabelecidas em um planejamento de ação podem ser drasticamente alteradas devido a contingências. Todo ambiente poderia ser concebido dentro das regras.

Uma teoria da física quântica, um ciclo de vida de um ser biológico, uma condição climática e assim por diante. Todas essas regras podem ser alteradas por contingências. Desta forma, uma ecologia sonora em nossa perspectiva deve ter regras, mas deve ser aberta a contingências capazes de alterar toda a estrutura. Em uma composição de paisagens sonoras, por exemplo, encontramos no ambiente gravado esta condição. Regras e contingências serão gravadas, mas quando gravadas, todas as dinâmicas de contingências são removidas, permitindo que o mesmo material seja reproduzido de forma idêntica. Obviamente, esta afirmação não é completa, pois consideramos que a percepção é a fonte pela qual o indivíduo determina um ambiente, com cada nova audição suas percepções sobre o material são variadas, criando contingências em segundo plano, um plano interpretativo do som. Consideramos esta condição válida, mas entendemos que não aborda totalmente o conceito de improvisação com este tipo de material. Esta condição pode ser um dos fatores da ausência de estudos de improvisação em conceitos ecológicos. Portanto, procuramos estabelecer que a 
percepção é o mecanismo pelo qual o indivíduo percebe o meio ambiente, mas as ações pelas quais ele atuará serão contingentes, permitindo mudar em algum nível as regras estabelecidas pela percepção.

Usando as ferramentas de comprovisação, elaboramos dois planos. Plano de diretrizes e plano de contingência. No plano de diretrizes, temos as regras e determinações que são os conteúdos que podem ser percebidos. E o plano de contingência seria as ações que mudam as regras. Estes dois planos nos permitiram desenvolver trabalhos artísticos que tentam simular ou reproduzir ecologias sonoras abertas a ações imprevisíveis. Essas obras foram usados como um estudo de caso para que pudéssemos investigar se essa simulação realmente ocorreu. Ou seja, adicionar características de improvisação em ecologias sonoras.

É relevante ressaltar que isso não deve ser entendido como uma unificação para propostas de inclusão de improvisação em práticas ecológicas. A comprovisação foi o método que encontramos para produzir um tipo de material que poderia ser investigado para responder a nossa pergunta inicial. Obviamente, pesquisas adicionais com grupos de controle maiores e produções artísticas mais sólidas devem ser produzidas para questionar se os resultados obtidos foram os mesmos. Outro fator que contribuiu para o uso desse método foi a ausência de material de referência. Como a improvisação parece ter pouca relevância para as práticas ecológicas, fomos forçados a encontrar soluções para a falta de material.

Assim, decidimos nos basear em propostas de modelagem socioecológica para ter uma formalização de como proceder a construir obras artísticas que tenham o caráter ecológico e, ao mesmo tempo, introduzir conteúdo contingente. É relevante ressaltar que as pesquisas em ecocomposição (KELLER et al. 2014) já possuem um certo nível de formalização para obras ecológicas, (mas não tratavam das contingências), portanto, consideramos utilizar uma teoria mais abrangente que agrega tópicos lineares para orientar a construção das obras artísticas que chamamos performance/experimentos.

Considerando que estamos trabalhando com a construção de simulações de ambientes que possuem diretrizes orientadas pela percepção e abertas a contingências e que cobrem auto organização e controle distribuído, desta forma, podemos afirmar que essa estrutura condiz com sistemas adaptativos complexos. Nas pesquisas desenvolvidas nesses sistemas, encontramos uma vasta área interdisciplinar. Essas pesquisas variam desde biologia, matemática, economia, sociologia e computação. Para a nossa formulação, utilizamos biologia (PAHL-WOSTL, 2007), sociologia (REED, 2008) e principalmente computação (SIBERTIN-BLANC et al., 2011) sempre apoiada pela pesquisa em ecocomposição (KELLER et al. 2014).

Usamos sistemas sócio-ecológicos como uma estrutura formal para a construção de performances/experimentos, e definimos padrões comuns para trabalhos 
em comprovisação ecológica. Em pesquisas de sistemas socioecológicos, utilizamos o termo entidades para definir: recursos materiais, recursos cognitivos e interação entre agentes. Diversos outros fatores podem e devem ser adicionados aos sistemas sócio-ecológicos, mas para este trabalho, os três itens atendem satisfatoriamente os tópicos investigados Pensamos nos recursos materiais como componentes e/ou ferramentas para a prática performática. Eles podem ser criados, explorados reinventados e permitem que as regras e as contingências ocorram.

Os recursos cognitivos estão diretamente ligados aos aspectos de percepçãoanálise-síntese propostos por Mannis (2014) tratados na frente. Esses recursos constituem o processo imaterial de comportamento. Em outras palavras, enquanto os recursos materiais demonstram quais objetos podem ser utilizados, os recursos cognitivos são a capacidade de reconhecer situações, planejar ações ou reações e realizar a atividade. É curioso perceber que os dois recursos podem ser adaptados nos planos comprovisacionais. No plano de diretrizes, podemos elaborar regras que determinarão o comportamento dos recursos materiais antes da performance/experimento. Definindo ferramentas, materiais, agentes do ambiente, espaços e até mesmo ações. Estes mesmos recursos podem ser trabalhados como diretrizes para recursos cognitivos, por exemplo: imitação de ferramentas e material, gestos organizados e ações rígidas de agentes com o meio. No plano contingencial, os recursos materiais e cognitivos permitem o processo exploratório (KELLER et al. 2014) e as ações imprevisíveis ou de erro. Por exemplo, redescobrindo o uso ou desenvolvendo ferramentas e materiais, liberdade de ação, imitação ou comportamento, exploração do meio ambiente e apropriação do espaço. A diferença é subdividida em dois fatores, o fator de tempo e as interações entre agentes. Nos planos de diretrizes, os recursos materiais e cognitivos podem ser pensados no tempo diferido. Mesmo que o conceito tenha surgido de uma contingência, ao formalizar a ação, ela se torna uma diretriz a ser repetida. Enquanto em planos de contingência, os recursos materiais e cognitivos são descobertos ou experimentados em tempo real, permitindo erros e imprevisibilidade.

O segundo fator capaz de influenciar as evidências seria a interação entre agentes, considerada outra entidade dos sistemas socioecológicos. As interações entre qualquer agente propõem modificações dinâmicas não-lineares ao sistema. Mais uma vez usando a metáfora de Fujak (2011), por mais planejado o processo seja, é o escopo de imprevisibilidade que redefine todo o sistema, como na vida. Para tentar entender que tipos de agentes estamos lidando, tentamos subdividi-los em alguns grupos e subgrupos:

Agentes performáticos: são aqueles que têm treinamento musical tradicional. Eles podem ser subdivididos em dois grupos: improvisadores e parafraseadores. Os parafraseadores são aqueles que não estão familiarizados com a improvisação, acostu- 
mados a lidar com diretrizes definidas (por exemplo, partituras). Os improvisadores são aqueles que têm maior capacidade de lidar com contingências. Esta é uma subdivisão primária suficiente para determinar dados quantitativos para esta pesquisa, no entanto, em pesquisas futuras, esta subdivisão pode incorporar variações mistas (improvisadores que dominam as diretrizes ou parafraseadores com habilidades contingenciais) no grupo de controle. Podem também incluir-se agentes performáticos que tenham dificuldades em planos, problemas de recursos materiais ou cognitivos em diretrizes e contingências.

Agentes incisivos: são aqueles que não possuem treinamento tradicional em música. Sua subdivisão foi determinada em: apreciadores e produtores. Os apreciadores são aqueles que estão envolvidos em práticas ecológicas criativas, mas evitam agir (intencionalmente). Os produtores são aqueles que procuram produzir algum mecanismo de interação com eventos. Esta subdivisão é semelhante às premissas dos agentes performáticos, isto é, uma sistematização simples, afinal, entre a subdivisão sugerida, pode haver migrações sem qualquer tipo de medição qualitativa. Outra crítica da subdivisão proposta é a generalização de agentes como não treinados tradicionalmente em música, limitando todas as outras formas de aprendizagem musical, tornando a subdivisão inconsistente. Outra inconsistência é adicionar agentes não humanos como incisos. Ou seja, os seres biológicos (como as aves, por exemplo) que estão presentes em uma performance/experimento são considerados agentes incisivos, pois podem participar das práticas criativas e produzir material relevante que pode ser incluído por outros agentes, no entanto, eles não tem nenhum tipo de treinamento musical tradicional. É claro que a subdivisão dos agentes incisos precisa de uma melhor definição e aprofundamento, mas foi suficiente para obter resultados para essa pesquisa e, eventualmente, pode ser expandida em outros níveis de pesquisa.

Com base na premissa de Fujak (2011) de que a imprevisibilidade é inevitável, consideramos abordar um "agente" imprevisível. Esta foi uma maneira de trazer os recursos de contingência pura para as práticas comprovisacionais. Assim, apresentamos o agente "Gelassenheit". Neste trabalho, Gelassenheit é um termo usado por Heidegger para sugerir processos que não podem ser explicados (mistério) e alinhados ao contexto do som por Koutsomichalis (2011) funciona como um tipo de definição para massas de som. Em comprovisações ecológicas, Gelassenheit é a pura contingência no meio ambiente. Não pode ser previsto, nem ser usado intencionalmente. Pode ser considerado como erro, ou processos estocásticos, ou mesmo eventos naturais imprevisíveis (como trovões). Mesmo que tentemos ajustar um gelassenheit em um plano de diretriz, não podemos saber quando um gelassenheit ocorrerá, apenas que pode acontecer. Por exemplo, um ambiente chuvoso pode gerar um trovão, podemos imaginar que isto podem ocorrer, mas não saberemos quando, nem como. 
Apresentados aos três tipos de agentes que acreditamos ser a base das interações comprovisacionais ecológicas, conseguimos formular os sistemas sócioecológicos diante nossas necessidades. De acordo com Sibertin-Blanc et al., (2011) o intercâmbio entre os três pilares das entidades: recursos materiais, cognitivos e agentes produz comportamentos que permitem a atividade. Aliel et al (2017) criticam a abordagem do autor sobre a questão da atividade que atinge necessariamente um objetivo. Os comportamentos podem gerar as atividades, mas estas não precisam necessariamente gerar um objetivo quantitativo e podem ser apenas uma resposta aos estímulos da performance/experiência.

Ainda assim, nos sistemas sócio-ecológicos, vários autores argumentam que existem duas formas de relacionamento entre as entidades: relação permanente estrutural e relação permanente não estrutural. A relação permanente estrutural é a relação que decorre a partir da própria natureza da entidade. A relação permanente não estrutural são as divergências associativas causadas por outras entidades, permitindo reações. Ou seja, o primeiro está relacionado às ações intencionais dos agentes, escolhas ou conhecimento básico de recursos cognitivos ou affordances de recursos materiais. No segundo, temos a imitação dos agentes, a imprevisibilidade e os erros dos recursos cognitivos e a exploração dos recursos materiais. Com base neste quadro teórico, propomos duas modelagens estáveis capazes de formalizar práticas comprovisacionais em ecologia sonora: proposta de modelagem em síntese ecológica (PMSE) e proposta de modelagem em loop (PL).

O PMSE é uma expansão do trabalho de Keller (1999) e busca expandir as possibilidades de interação material, cognitiva e de interação entre agentes usando o ambiente ecológico real, o ambiente ecológico sintetizado e o metasoundscape (ALIEL; FORNARI, 2013). Nessas três configurações, as três entidades se limitam a imitar e a explorar a partir de atividades epistêmicas. Essa expansão foi a base de quase todas as performances/experimentos e nos permitiu coletar dados que nos ajudaram a demonstrar como ocorrem alguns comportamentos. Ao colocar ambientes naturais em acomodação ou incompatibilidade com outras formas de ambientes (sintetizados ou remotos), habilitamos recursos materiais, cognitivos e interações drasticamente variáveis. Podemos considerar portanto que, no plano de diretrizes, fica a construção do mecanismo para que a relação entre ambientes possa ocorrer. $E$ toda e qualquer ação gerada a partir desta relação incorpora o plano de contingência.

PL é uma expansão do trabalho de Di Scipio (2013) e trata da retroalimentação de dados no sistema sócio-ecológico, permitindo que, com cada nova alimentação, o processo possa dinamizar de maneira não linear o sistema. Acreditamos que qualquer repetição, idêntica ou não, está sujeita a uma interpretação divergente entre os agentes, possibilitando mudanças no sistema. Mesmo que coloquemos um agente em contato 
com um recurso material em looping, os recursos cognitivos seriam alterados em cada alimentação, permitindo interações variáveis no sistema. Desta forma, o looping se encaixa no plano de diretrizes e os recursos cognitivos e as interações no plano de contingência.

Com essa estrutura construímos quatro estudos de caso:

Destino Pirilampo trabalha com a manipulação de metasoundscapes (unificação de paisagens sonoras remotas) em conflito/acomodação com a paisagem de som real. Ele usa o PMSE em sua construção e foi a primeira constatação de que podemos desenvolver obras de ecologia sonora, adicionando o recurso de contingências (improvisações) sem perdas significativas da perspectiva ecológica. Obtivemos resultados técnicos que podem ser explorados em outras comprovisações ecológicas, tais como:

- Adaptação de recursos cognitivos a recursos materiais em um contexto de imprevisibilidade natural;

- Equivalência entre agentes performáticos e agentes incisos no ambiente criativo;

- Construção de algoritmos computacionais que permitem planos de diretrizes e contingentes;

- Interações entre agentes de forma remota;

Citações - performance/experimento que busca criar múltiplas camadas de som sintetizado e natural, visando uma modificação da paisagem sonora real. $O$ trabalho usa PL e permitiu a expansão da introdução de recursos cognitivos em ambientes reais através da interação de agentes. Os resultados técnicos alcançados:

- Validação de erros como um fator primário para a modificação do sistema;

- Assumir a entidade Gelassenheit como pré-requisito para uma comprovisação ecológica consistente;

- Fluxogramas de opções capazes de permitir ações de permanente estrutural e permanente não-estrutural;

- Uso de recursos gravações (samples) para expansão de modificações de instâncias perceptivas;

Lyapunov Time - Performance/Experimento que investigou as relações de agentes performáticos com atividades que exigiram a tomada de decisão. $O$ trabalho usa 
uma mistura de PL com PMSE. PL porque os recursos de material acústico e eletrônico estão funcionando a partir de repetições. PMSE porque adicionamos uma camada de som processada de forma semelhante ao som do ambiente produzido pelos instrumentos acústicos. $\mathrm{O}$ foco do experimento foi sobre a manipulação de recursos materiais gravados a partir de improvisações ou ensaios anteriores da peça, sendo estas manipulada em tempo real seguindo diretrizes escolhidas aleatoriamente. Conceitualmente, procuramos uma expansão na técnica em comprovisação de Hannan (2006) que cria obras concretas a partir de gravações de improvisações livres. Buscamos transformar essa técnica em algo mais dinâmico, permitindo que o processamento sonoro interfira em sons gravados via live electronics. Esta proposta gera um sistema mais complexo e adaptativo. Os resultados técnicos alcançados:

- Processamento sonoro contingencial de samples de áudio;

- Processamento contingencial de samples de vídeo;

- Introdução das técnicas estendidas instrumentais como recursos comprovisatórios;

- Interação entres algoritmo estocásticos e tomada de decisões entre agentes;

- Estruturação formal da peça se baseada em sistemas dinâmicos não-lineares;

- Fluxograma de opções como recurso para tomada de decisões;

- Construção de partitura narrativa via reprodução em vídeo;

The Maxwell Demon - Esta performance/experimento foi desenvolvida para avaliar como os agentes interagem em comprovisações ecológicos de forma grupal. Utilizamos o PMSE para propor várias interações de som ao meio ambiente. Cada agente possui uma fonte de som baseada na síntese e adicionamos o mesmo algoritmo controlado por uma máquina de forma estocástica. Preparamos um questionário semiestruturado para analisar qualitativamente e realizamos observações em registros de vídeo para análise quantitativa. Foram coletados dados curiosos, tais como:

- Imitação e adaptação à agentes em estado de hierarquia;

- Desenvolvimento de padrões de exploração baseados na percepção-análisesíntese;

- Produção de recursos materiais mais relevantes em proporção ao maior domínio técnico; 
- Fonte principal de resolução de problemas com base na organização de parâmetros de som;

- Subdivisão de grupo sem uma delimitação planejada anteriormente;

- Não há dissolução perceptual de agentes biológicos para máquinas;

Para analisar os estudos de caso desenvolvidos nesta dissertação, utilizamos e ampliamos dois modelos, o modelo de Mannis (MANNIS, 2014) e o modelo Dentro-Fora (FERRAZ; KELLER, 2014). O modelo de Mannis (MM) explica basicamente em nossa perspectiva, como os agentes percebem o meio ambiente, analisam suas condições e possibilidades e sintetizam seu comportamento diante de eventos. Mannis acredita que grande parte dessas interações vem do processo de imitação. Este trabalho mediu esta premissa de várias maneiras nos estudos de caso, e ressaltamos que, em ambientes com diretrizes e contingências, a maioria das interações realmente vem da imitação, confirmando a hipótese de Mannis. Encontramos algumas condições que não são sugeridas por Mannis, como o planejamento de ações de tempo diferido. Esta condição diversifica drasticamente ambientes envolvidos em sistemas socioecológicos, reduzindo as condições de imitações, criando condições de disputa ou comportamentos hierárquicos.

Para uma análise quantitativa do material, o modelo Dentro-Fora (MDF) propõe diversas formas de análise. Neste trabalho, nos limitamos a avaliar o sistema através de três categorias: Consensualidade de interação, pregnância/relevância de recursos materiais, produção de resíduos criativos. No processo de interação consensual, buscamos apontar que as interações entre agentes determinam ações em acomodação ou contraste. Quanto mais consensual a interação, por exemplo, através da imitação, maior a acomodação do material sonoro, quanto menor a interação consensual, maior o contraste. Observamos a existência de ferramentas de interação consensual, como imitação e pregnância. A pregnância neste trabalho é entendida como um recurso de som que permanece no sistema. Pode vir de fontes externas ou internas. Quanto mais tempo continuar sendo manipulado, mais relevante será considerado e, portanto, mais interação consensual existirá. Por exemplo, no caso de uma célula rítmica que se torne pregnante, fazendo com que todos os envolvidos reproduzam essa célula, ela será considerada altamente relevante e determinará uma condição de interação consensual total, afinal, todos os envolvidos foram contaminados por ela. Em relação ao resíduo criativo, esse tipo de material ocorre basicamente quando a interação consensual é baixa, produzindo material com baixa pregnância que acaba sendo descartado. Quanto maior o descarte, menor a interação e a impregnação do material. No entanto, o recurso material que foi descartado pode ser reutilizado em outro momento e produzir um alto grau de pregnância. Esta condição não é um evento isolado e não encontramos um 
mecanismo para medir ou analisar os motivos para que esse fator ocorra. Acreditamos que, com um aprofundamento da pesquisa nesse escopo, é possível obter melhores resultados.

Finalmente, acreditamos que este trabalho desenvolveu o seu papel de propor condições de improvisação sonora dentro do nicho de pesquisa em práticas ecológicas. Obviamente, devido à ausência de outras pesquisas, este trabalho aparece como um passo inicial para este tipo de proposta. A comprovisação, como sugerida, é apenas um método para esse tipo de abordagem. Em pesquisas futuras, acreditamos que este trabalho pode ser desenvolvido em três linhas gerais:

1) Aplicações de performances/experimentos multimodais com uma metodologia mais consistente, com base em pesquisas art practice research. Onde podemos configurar de forma mais eficaz como produzir performances artísticas e, ao mesmo tempo, coletar dados que possam responder a perguntas;

2) Com base nos dados coletados nas performances/experimentos, gerar ferramentas e discussões sobre o comportamento dos recursos cognitivos em relação aos recursos materiais em práticas ecológicas;

3) Aplicações educacionais baseadas na perspectiva dos planos de diretrizes e planos de contingência, em relação aos agentes performático e/ou incisos. Suas condições, relevância e contradições. 


\section{Referências Bibliográficas}

ALIEL, L.; FORNARI. J. Projeto Destino Pirilampo: Um Estudo sobre a Composição de Meta- Soundscapes em Música Ubíqua. Música Hodie, v.14, p. 105- 121. 2014.

ALIEL, L., KELLER, D., COSTA, R., MELO, M. T. S., PINHEIRO da SILVA, F., ANDRADE, L. S., Práticas Ecocognitivas Improvisatórias: Dois Estudos de Caso, In: VI Ubimus, Disponível em: http://lammax.Inu.se/ubimus/. 2015.

ALIEL, L., KELLER, D., COSTA, R., MELO, M. T. S., PINHEIRO da SILVA, F., SANTOS, L. A.; Eco-cognitive Improvisational practice: Two case studies. In: VI Ubimus, 2015, Vaxjo. Ubiquitous Musical Ecologie, 2015a.

ALIEL, L., KELLER, D., COSTA, R. Comprovisação Abordagens Desde a Heurística Estética em Ecocomposição In: SBCM - XV Simpósio Brasileiro de Computação Musical, 2015, Campinas/SP. SBCM - XV Simpósio Brasileiro de Computação Musical. , 2015.

ALIEL, L., KELLER, D., COSTA, R.; Perspectivas Teóricas para a Análise das Práticas Criativas Ecocognitivas. Per Musi (UFMG), 2016.

AMABILE, T. M. The Work Preference Inventory: Assessing intrinsic and extrinsic motivational orientations. In: Society for Industrial and Organizational Psychology, Orlando, FL. 1995.

ARKETTE, S. Sounds Like City, Theory, Culture \& Society 21, 159 - 168. 2004.

BACKHOUSE, J. Chi-ca-go [Live vocal plus electronics work]. Chicago, IL, USA, 2011. Disponível em: http://www.jedbackhouse.com/chimiddotcamiddotgo-2011.html.

BARBOSA, A. Performance Musical em Rede. In: Damián Keller e Rogério Budasz 
(ed.). Criação Musical e Tecnologias: Teoria e Prática Interdisciplinar. Goiânia: ANPPOM, p.97-126.2010. Disponível em <http://anppom.com.br/editora/Pesquisa_em _Musica-02.pdf.>.

BARDRAM, J. E. Activity-based computing: support for mobility and collaboration in ubiquitous computing. Personal and Ubiquitous Computing 9, 312-322. 2005.

BARREIRO, D. L.; KELLER, D. Composição com Modelos Sonoros: Fundamentos e Aplicações Eletroacústicas. In: Damián Keller e Rogério Budasz (ed.). Criação Musical e Tecnologias: Teoria e Prática Interdisciplinar. Goiânia: ANPPOM, p.97 -126. 2010. Disponível em: $<$ http://anppom.com.br/editora/Pesquisa_em_Musica-02.pdf>.

BARRETT, N. A compositional methodology based on data extracted from natural phenomena. In: Proceedings of the International Computer Music Conference (ICMC 2000) (pp. 20-23). Ann Arbor, Ml: MPublishing, University of Michigan Library. 2000.

BASANTA, A. Syntax as sign: The use of ecological models within a semiotic approach to electroacoustic composition. Organised Sound 15 (2), 125-132. (Doi:10.1017/S135577181000011 2010.

BHAGWATI, S. Towards Interactive Onscreen Notations for Comprovisation in Large Ensembles. In: Sound \& Score: Essays on Sound, Score and Notation. 2014.

BERKELEY, G. Philosophical Works (Michael R. Ayers, ed.). London, Everyman, 1975.

BOWN, O., ELDRIDGE, A., MCCORMACK, J. Understanding interaction in contemporary digital music: From instruments to behavioural objects. Organised Sound 14, 188-196. (Doi: 10.1017/S1355771809000296.). 2009.

BOULEZ, P. Orientations: Collected Writings. London, UK: Faber and Faber. (ISBN: 0571143474.) 1986. 
BRYAN-KINNS, N., HEALEY, P. G. T. Daisyphone: Support for Remote Music Collaboration. In: Proceedings of NIME 2004, Hamamatsu, Japan, pp. 27-30. 2004.

BURNARD, P., YOUNKER, B. A. Mapping pathways: Fostering creativity in composition. Music Education Research, 4(2), 245 - 261.

BURTNER, M. EcoSono: Adventures in interactive ecoacoustics in the world. Organised Sound, v.16. 2011.

BURTNER, M. Ecoacoustic and shamanic technologies for multimedia composition and performance. Organised Sound 10, 3-19. (Doi: 10.1017/S1355771805000622.) 2005.

CAGE, J. Silence. Middletown CT, Wesleyan Univ Press. 1961.

COSTA, R. L. M. A ideia de jogo em obras de John Cage e no ambiente da livre improvisação. Per Musi, (19), 83-90. 2009.

COSTA, R. L. M. Livre improvisação e ecologia sonora: uma aproximação a partir da estética da sonoridade. Opus (Belo Horizonte. Online), v. 20, p. 189-206, 2014.

COSTA, C. A., YAMIN, A. C. e GEYER, C. F. R. Toward a General Software Infrastructure for Ubiquitous Computing. IEEE Pervasive Computing 7(1), 64-73. 2008.

CHEN, P., PIN-SHAN, P., The Entity-Relationship Model - Toward a Unified View of Data. ACM Transactions on Database Systems 1 (1): 9-36. 1976.

DI SCIPIO, A. Émergence du Son, Son d'emergence: Essai D'épistémologie Expérimentale par un Compositeur. Intellectica 48-49, 221-249. 2008.

DI SCIPIO, A. A Sound is The Interface: From Interactive to Ecosystemic Signal Processing. Organised Sound, 8(3):269-277, 2003.

DUDAS, R. Comprovisation: The Various Facets of Composed Improvisation within Interactive Performance Systems, Leonardo Music Journal 20 p. 29-31. 2010. 
EAGLESTONE B, FORD N, HOLDRIDGE P, CARTER J, UPTON C. Cognitive styles and computer-based creativity support systems: two linked studies of electro-acoustic music composers. In: Kronland-Martinet R, Ystad. S, Jensen. K, (eds) Computer music modeling and retrieval: sense of sounds. Springer, Berlin/Heidelberg, $p p$ 74-97. ISBN 978-3-540-85034-

FERRAZ, S.; KELLER, D. MDF: Proposta Preliminar do Modelo Dentro-Fora de Criação Coletiva. Cadernos de Informática (UFRGS), v. 8, p. 57-67. 2014.

FERRAZ, S; Música e repetição: aspectos da diferença na composição contemporânea. São Paulo: EDUC, 1998

FORNARI, J. Interatividade Musical à Distância. Anais do 6 Encontro de Música e Mídia. 15-17 Setembro 2010.

FUJAK, J. Comprovisación - Notas para la discusión sobre la validez delconcepto, Oro Molido No. 33, Madrid, Spain. 2011.

GIAMPIETRO, M, Complexity and Scales: The Challenge for Integrated Assessment. Integrated Assessment, 3 (2-3), 247-265. 2002.

GIBSON, J. J. The ecological approach to visual perception. Boston, MA: Houghton Mifflin. (ISBN: 0898599598.) 1979.

GLAVEANU, V. Creativity as action: findings from five creative domains. Frontiers in psychology 4 (2013).

HANNAN, M Interrogating Comprovisation as Practice-led Research, in Speculation and Innovation: applying practice led research in the creative industries, Brisbane: Queensland University of Technology, http://www.speculation2005.qut.edu.au , now accessible at http://epubs.scu.edu.au/sass_pubs/448/. 2006.

HARRIS, Y. Taking soundings: A composers' investigations into technologies of na- 
vigation. In: Conference Proceedings of MutaMorphoses: Challenging Arts and Sciences. 2009.

HEIDEGGER, M; Gelassenheit: HarperCollins. 1966.

HELSON, R. The Creative Personality. In: K. Gronhaugh \& G. Kaufman (ed.), Innovation: A Cross-Disciplinary Perspective (pp. 29-64). Oslo: Norwegian University Press. 1988.

HUTCHINS, E. Cognition in the Wild. Cambridge, MA: MIT Press. (ISBN:9780262082310.). 1995.

IAZZETTA, F. Processos musicais: entre a experimentação e a criação. Ressonâncias: Revista de investigación musical, v. 19, p. 141-146, 2015.

IGLESIA. D. The Mobility is the Message: the Development and Uses of Mob Mu plat. In: PdCon16. NYC. 2016. http://www.danieliglesia.com/mobmuplat/Iglesi aMobMuPlatPaper.pdf

KELLER, D. touch'n'go: Ecological Models in Composition. Master of Fine Arts Unpublished master's thesis, Burnaby, BC: Simon Fraser University. http://www.sfu.ca/s onic-studio/srs/EcoModelsComposition/Title.html. 1999.

KELLER, D. Paititi: a multimodal journey to El Dorado. Tese (Doutorado em Artes Musicais) Stanford University. Stanford, CA, 2004. Disponível em: $<$ http://portal.acm.or g/citation.cfm?id=1048456 $>$.

KELLER, D. Sonic Ecologies. In: A. R. Brown (ed.),, Vol. Sound Musicianship: Understanding the Crafts of Music (pp. 213-227). Newcastle upon Tyne, UK: Cambridge Scholars Publishing. (ISBN: 978-1-4438-3912-9.). 2012.

KELLER, D. Compositional processes from an ecological perspective. Leonardo Music Journal 10, 55-60. (Doi: 10.1162/096112100570459.). 2000. 
KELLER, D., BARREIRO, D. L., QUEIROZ, M., PIMENTA, M. S. Anchoring in ubiquitous musical activities. In: Proceedings of the International Computer Music Conference (pp. 319-326). Ann Arbor, Ml: MPublishing, University of Michigan Library. 2010.

KELLER, D.; CAPASSO, A. New concepts and techniques in eco-composition. Organised Sound 11 (1), 55-62. (Doi: 10.1017/S1355771806000082.) 2006.

KELLER, D., BUDASZ, R., Criação Musical e Tecnologias: Teoria e Prática Interdisciplinar, Vol. 2. Goiânia, GO: Editora ANPPOM. (ISBN: 978-85-63046-01-7.). 2010.

KELLER, D.; CAPASSO, A. Social and perceptual processes in the installation The Trade. Organised Sound 5 (2), 85-94. (Doi: 10.1017/S1355771800002053.) 2000.

KELLER, D., LAZZARINI, V., PIMENTA, M. S., (ed.). Ubiquitous Music, Vol. XXVIII. Berlin and Heidelberg: Springer International Publishing. (ISBN: 978-3-319-11152-0.). 2014.

KELLER, D., TIMONEY, J., COSTALONGA, L., CAPASSO, A., TINAJERO, P., LAZZARINI, V., PIMENTA, M. S., de Lima, M. H., \& JOHANN, M. Ecologically grounded multimodal design: The Palafito 1.0 study. In: Proceedings of the International Computer Music Conference (ICMC 2014). Ann Arbor, MI: MPublishing, University of Michigan Library. 2014c.

KOUTSOMICHALIS, M., Site Specific Live Electronic Music: A Sound Artist's Perspective, Proceedings of the Electroacoustic Music Studies Conference, Sforzando!, New York. 2011. Visto em: 22 de Abril de 2016, <http://www.emsnetwork.org/IMG/pdf_ EMS11_Koutsomichalis.pdf $>$.

LIMA, M. H., KELLER, D., OTERO, N., PIMENTA, M. S., LAZZARINI, V., JOHANN, M. \& COSTALONGA, L. Ecocompositional techniques in ubiquitous music practices in educational settings: Sonic sketching. In: E. Himonides \& A. King (ed.), Proceedings of the SEMPRE (MET2014): Researching Music, Education, Technology: Critical Insights (pp. 123-127). London: iMerc. 2014. 
LOCKHART, A.; KELLER, D., Exploring cognitive process through music composition. In: Proceedings International Computer Music Conference (ICMC 2006) (pp. 9-12). Ann Arbor, MI: MPublishing, University of Michigan Library. 2006.

LOWGREN, J. Toward an articulation of interaction esthetics. New Review of Hypermedia and Multimedia 15.2 (2009): 129-146.

MAILMAN, J. B. Improvising Synesthesia - Comprovisation of Generative Graphics and Music, Leonardo Electronic AImanac (LEA), Volume 9, Issue 3, Leonardo/ISAST, San Francisco, California, USA, (2013)

MALT, M. Lambda 3.99 (Chaos, et Composition Musicale). In: G. Assayag \& M. Chemillier (ed.), 3emes Journées d'Informatique Musicale (JIM96). Île de Tatihou, Basse Normandie, France: JIM. 1996.

MANNIS. J. A. Processos Cognitivos de Percepção, Análise e Síntese Atuando no Processo Criativo Mimesis de Mimesis. In: Encontro Nacional de Composição Musical de Londrina - EnCom 2014. 2014

MELO, M. T., KELLER, D. (2013). Tocaflor: exploração da marcação procedimentalgráfica em uma obra mista. In: D. Keller \& M. A. Scarpellini (eds.), Anais do II Simpósio Internacional de Música na Amazônia. Rio Branco, AC: NAP.

NANCE, R. W. Compositional explorations of plastic sound. Doctoral Thesis in MusicUnpublished doctoral disseration, DeMontfort University, UK. (2007).

OAKLEY, A., Gender, Methodology and People's Ways of Knowing: Some Problems with Feminism and the Paradigm Debate in Social Science, Sociology 32(4), 707 - 731. 1998.

OPIE, T.; BROWN, A. An introduction to eco-structuralism. In: Proceedings of the International Computer Music Conference (ICMC 2006) (pp. 9-12). Ann Arbor, MI: MPublishing, University of Michigan Library. 2006. 
PAYNE, S. R., DAVIES, W. J., ADAMS, M. D. Research Into the Practical and Policy Applications of Soundscape Concepts and Techniques in Urban Areas (NANR 200), Technical Report May. 2009.

PAHL-WOSTL, C., Transitions towards adaptive management of water facing climate and global change. Water Resources Management, 21: 49-62. 2007.

PINHEIRO DA SILVA, F.; KELLER, D.; SILVA, E. F.; PIMENTA, M. S.; LAZZARINI, V. Criatividade Musical Cotidiana: Estudo Exploratório de Atividades Musicais Ubíquas. Música Hodie, v. 13, p. 64-79. 2013.

PINHEIRO DA SILVA, F., PIMENTA, M. S., LAZZARINI, V.; KELLER, D. A Marcação Temporal No Seu Nicho: Engajamento, Explorabilidade e Atenção Criativa. Cadernos de Informática (UFRGS), v. 8, p. 45-56, 2014.

PRESSING, J. Psychological Constraints on Improvisational Expertise and Communication, In: The course of Performance: Studies in the World of Musical Improvisation. Ed. Bruno Nettl and Melinda Russel Chicago, (University of Chicago Press, 1998), 53 54.

PUCKETTE, M. Pure Data. Proceedings, International Computer Music Conference. (pp. 269-272.) San Francisco: International Computer Music Association. 1996.

RANDOLPH, J. J. A Guide to Writing the Dissertation Literature Review. In: Practical Assessment, Research \& Evaluation 14, p. 1-13. 2009.

ROTMANS, J.; ASSELT, M., Integrated assessment: A growing child on its way to maturity. Climatic Change 34 (3) 327. 1996.

SANFILIPPO D.; VALLE, A. Heterogeneouslycoupled feedback systems. the - (bar dot) project, In: Proceedings of International Computer Music Conference 2012, Ljubljana, 2012. 
SCHAFER, R. M. (2001) A afinação do mundo. São Paulo: Ed. UNESP.

SCHAFER, R. M. The Soundscape: Our Sonic Environment and the Tuning of the World, Destiny. Vermont. 1977.

SOLOMOS, M. Entre Musique Et Écologie Sonore: Quelques Exemple. Revue Sonorités, Rencontres Architecture Musique Ecologie, Paris, n. 7, p. 167 -186, 2012.

SCHULTE-FORTKAMP, B.; FIEBIG, A. Soundscape Analysis in a Residential Area: An Evaluation of Noise and People's Mind. In: Acta Acustica united with Acustica 92, 875 - 880. 2006.

SOUTHWORTH, M., The Sonic Environment of Cities, In: Environment And Behavior, p. 49 - 70. 1969.

TRAUB, P. Sounding the Net: Recent Sonic Works for the Internet and Computer Networks. Contemporary Music Review. Vol. 24, 2005. p. 459 - 481. 2005.

TRUAX, B. Genres and Techniques of Soundscape Composition as Developed at Simon Fraser University. In: Organised Sound., p. 7:5-14 2002.

TRUAX, B. Acoustic Communication, In: The Soundscape Newsletter \#5. 1993.

TRUAX, B. Acoustic Communication, 2nd edn, Ablex. 2001.

TRUAX, B. and BARRETT, G. W., Soundscape in a Context of Acoustic and Landscape Ecology, Landscape Ecology 26(9), 1201 - 1207. 2011.

VARELA, F. J. Whence perceptual meaning? A cartography of Current Ideas. In: F. J. Varela \& J.-P. Dupuy (ed.),Understanding Origins, Vol. 130 (pp. 235-263). Amsterdam, Netherlands: Springer. (ISBN: 978-90-481-4090-9.) Retrieved from http://dx.doi.or g/10.1007/978-94-015-8054-0_13. 1992. 
VILLENA, M. R. Música ubíqua e paisagens sonoras. Possíveis contribuições. In: Cadernos de Informática. V.8 n.4 2014.

VIVIER, O. Varèse, Éditions du Seuils, Paris. 1973.

WEISER, M. The Computer for the Twenty-First Century, Scientific American 265(3), 94-101. 1991.

WELSCH, W. Transkulturalitat. Lebensformen nach der Auflosung der Kulturen. In: Information Philosophie. 1992.

WEN-CHUNG, C. Varèse: A Sketch of the Man and his Music. Musical Quarterly, p. 151-170, 1966.

WESTERKAMP, H. Kits Beach Soundwalk [for spoken voice and two-channel tape]. Montreal: DIFFUSION i MeDIA / empreintes DIGITALes Compact Disc Transformations. 1996.

WESTERKAMP, H. Linking Soundscape Composition and Acoustic Ecology. In: Organised Sound 7, 51 - 56. 2002.

WEISSER, C.; DOBRIN, S. Ecocomposition: Theoretical and Pedagogical Approaches. Albany: SUNY. 2001.

WINDSOR, W. L. A perceptual approach to the description and analysis of acousmatic music. Doctoral Thesis in Music, London: City University. 1995.

XENAKIS, I. Theory and Applications of Cellular Automata, Singapure: WorldScientific. Formalized Music, Bloomington, In: Indiana University Press. 1971. 